JOANA MARIA VIEIRA ROBALO FERREIRA DE ALMEIDA GUIMARÃES

\title{
SUICÍDIO MÍTICO
}

\section{UMA LUZ SOBRE A ANTIGUIDADE CLÁSSICA}

Faculdade de Letras da Universidade de Coimbra 


\section{SUICÍDIO MÍTICO}

\section{UMA LUZ SOBRE A ANTIGUIDADE CLÁSSICA}

Dissertação de Mestrado em Estudos Clássicos - Mundo Antigo, apresentada à Faculdade de Letras da Universidade de Coimbra sob a orientação do Professor Doutor Francisco de Oliveira

Trabalho desenvolvido no âmbito do plano quadrienal de actividades do Centro de Estudos Clássicos e Humanísticos da Universidade de Coimbra / FCT POC 2010

Faculdade de Letras da Universidade de Coimbra 


\section{Agradecimentos}

Agradeço ao Professor Doutor Francisco de Oliveira. Foi incomensurável o que fez, que nunca me deixou sozinha no árduo caminho desbravado. Muito aprendi com a sua honestidade e o seu rigor intelectuais, com a sua atitude sempre tão atenta, tanto nas linhas delineadoras e genéricas, como nos detalhes mais subtis. Por tudo isso, o meu mais profundo obrigada.

Ao Professor Doutor José Ribeiro Ferreira, coordenador do Mestrado Mundo Antigo, além de agradecer o encantamento que foi redescobrir a Arte Grega através do seu entusiasmo contagiante e sensibilidade, agradeço também o acolhimento tão generoso no seio do Instituto de Estudos Clássicos da Universidade de Coimbra.

Todos os mestres que aí tive, todos eles, de forma única, me fizeram sentir, no final de cada aula, mais enriquecida. A todos eles, o meu sentido obrigada.

Um abraço, à Ana Catarina, pela amizade de uma vida, curso de um longo rio.

Ao Serafim e aos meus filhos, por tudo o que foi dado, todas as palavras que possam exprimir o meu obrigada, e são elas uma infinitude, todas elas me sabem inexoravelmente aquém. 
Aos meus filhos,

João Maria, Miguel e Margarida, a quem quero transmitir que a aprendizagem e o saber conduzem a uma maior fruição da vida e, portanto, a uma maior felicidade. 


\section{ÍNDICE GERAL}

Resumo 2

Notas Prévias 3

I. Introdução

II. Organização do Corpus e sua Tipologia $\quad 8$

1. Modus operandi para a recolha dos dados 8

2. Tipologia do Corpus 12

2.2 Motivos para o suicídio - causae moriendi 12

2.2.1 Devotio 13

2.2.2 Taedium vitae 15

2.2.3 Dolor 16

2.2.4 Desperata salus 17

2.2.5 Pudor 18

2.2.6 Conscientia 20

2.2.7 Furor 22

2.2.8 Impatientia doloris $\quad 23$

2.2.9 Necessitas 23

2.2.10 Exsecratio 25

2.2.11 Iactatio $\quad 26$

2.3 Modos para o suicídio - modi moriendi 27

III. Corpus

IV. Temáticas Emergentes

V. Conclusão 124

VI. Apêndice - Tratamento Estatístico 127

$\begin{array}{ll}\text { VII. Bibliografia } & 138\end{array}$ 


\title{
Resumo
}

No presente trabalho, constitui-se um corpus com os mitos Greco-Romanos onde existe intenção concretizada de alguém se suicidar. As fontes foram dicionários, enciclopédias e autores antigos. Constituiu-se uma grelha classificativa, aplicada a cada entrada e na qual a lógica construtiva foi resultado de reflexão sobre como distinguir e caracterizar os motivos e os modos que levaram ao acto. Compararam-se sempre os resultados obtidos com o estudo de Anton van Hoof: From Autothanasia to Suicide. O corpus inventariado representa um número de suicídios muito superior ao anteriormente referenciado e a tipologia proposta é mais elaborada.

As duzentas e trinta e uma entrada revelam que os mitos se constituem, sobretudo, por mitos epónimos e etiológicos, fundamentalmente ligados a rios, mas também a outras especificidades marítimas. Foi possível, igualmente, identificar padrões de comportamento feminino e masculino e perceber características culturais, sociais e factos históricos das épocas em que os mitos se encontram inseridos.

\begin{abstract}
The present work is composed by a corpus with Greco-Roman myths in which there has been intent to commit suicide. Used sources were dictionaries, encyclopaedias and ancient documents. A classifying grid was created and applied to each entry. It was conceived to identify and characterize the way motives and methods lead to the act of suicide. Every result was compared to Anton Von Hoff's study "From Autothanasia to Suicide". The whole list of entries compiled in the corpus represents a considerably higher number than early referred and the proposed typology is more complex.

The two hundred and thirty one gathered entries show that myths are, essentially, eponyms and etiological myths, mainly related to rivers, but also to other maritime specificities. It was also possible to identify patterns of male and female behaviour and understand cultural and social characteristics, as well as historical facts of epochs to which those myths belong.
\end{abstract}




\section{Notas Prévias}

\section{Abreviaturas e siglas utilizadas:}

BNP = Brill's Encyclopädia of the Ancient World. New Pauly. Antiquity. Eds H. Cancick, H. Schneider; engl. ed.: Ch. F. Salazar, D. E. Orton. LeidenBoston, 2002-.

Grimal = P. Grimal $\left({ }^{15} 1951\right)$, Dictionnaire de la Mythologie Grecque et Romaine. Paris, Presses Universitaires de France.

Lexikon = Lexikon der Alten Welt (1965) Eds. C. Andresen et alii. Zürich Stuttgart, Artemis Verlag.

RE $=$ Paulys Realencyclopädie der Classischen Altertumswissenschaft (1893). Neue Bearbeitung, hrsg. G. Wissowa. Stuttgart, Alfred Druckenmüller Verlag.

Van Hoof = A. J. L. van Hoof (1990), From Autothanasia to Suicide. Self-Killing in Classical Antiquity. London, Routledge.

\section{Aparato crítico do Corpus}

No aparato crítico, enuncia-se o motivo, o meio, os temas sugeridos, as fontes consultadas e o resultado de Van Hoof acerca dessa entrada. No que concerne este autor, referimos pela seguinte ordem: motivo, modo, sinal + ou - consoante houve ou não concretização do suicídio; no caso de algum destes três items não ter sido esclarecido, está um ponto de interrogação. Segue-se a fonte antiga.

\section{Autores antigos}

Não são especificadas as inúmeras edições de autores antigos, onde recorremos essencialmente a edições bilingues (primariamente Budé e Loeb) ou a traduções para espanhol, francês, inglês, português. Resalvam-se os casos de citações feitas fora do corpus.

\section{Mitónimos}

A tradução portuguesa dos mitónimos baseou-se em F. Rebelo Gonçalves (1966), Vocabulário da Língua Portuguesa. Coimbra, Coimbra Editora. 


\section{Introdução}

A procura é incessante e centra-se num objectivo que tem a dupla face da inacessibilidade e do fascínio: conhecer o Mundo Antigo e entendê-lo na vastidão de todas a suas sinuosidades. Para tal, procedemos a uma pesquisa exaustiva, numa tentativa de identificar todos os mitos greco-romanos unidos pelo cunho do suicídio. Veremos que este se apresentará sob múltiplas roupagens, peças únicas de um corpus pujante e complexo. A pesquisa feita trouxe mais conhecimento sobre este passado e, nesse sentido, iluminou-o. Para nós, o suicídio foi uma portentosa ferramenta de compreensão e, mais do que isso, uma interrogação desassombrada sobre a Antiguidade Clássica.

Nos mitos encontramos narrativas sobre deuses e heróis. Se pensarmos nestas narrativas como um mapa psicológico da Antiguidade, poderemos estabelecer pontes umbilicais, identificativas entre o mundo mitológico e o mundo real de então, pois, como diz Van Hoof, "pela sua natureza, o material mítico pertence à esfera das mentalidades" $"$.

Muitos dos personagens que protagonizam estes mitos pertencem ao legado literário que chegou até nós. As tragédias são palcos privilegiados que ilustram bem essa situação. Estudar as atitudes suicidárias dos seus personagens é aprofundar a ligação intrínseca existente entre o plano real e o plano mítico².

Etimologicamente, suicidium (suícidio) compõe-se de sui (de si) e caedes (morte violenta, imolação), mas esta sua pertença latina não oblitera o facto de a palavra só

\footnotetext{
${ }^{1}$ Van Hoof 199013.

${ }^{2}$ A este propósito, diz Garrison 1995 1: "All three tragedians use the motif of suicide for exploring the interrelationship of tragic figures with family, political systems and gods, for exploring the actions of an idealized individual within ethical context".
} 
surgir no século XVIII, sob a égide de um teólogo chamado Caramuel ${ }^{3}$. Geralmente, os filósofos latinos vêem este acto, seja como uma partida precipitada, veja-se o caso de uma fuga da vida (vitam fugere), expressão encontrada em Cícero, Virgílio, Séneca ou Tácito; seja como uma saída tranquila ou marcha calma, como por exemplo, e vita exire, a vita discedere e obviam morti procedere, em Cícero também, ou ad mortem ire em Lucrécio ${ }^{4}$. Nestas atribuições, não se sente o carácter estigmatizante da etimologia de suicídio. Juntando este aspecto ao facto de existirem, ao invés, termos específicos na língua latina antiga para designar outras mortes, tais como parricidium, homicidium, matricidium, fratricidium, infanticidium, tyrannicidium, podemos assinalar desde já um corpo moral distinto da tradição cristã, onde o suicídio se cristaliza num tema tabu com Santo Agostinho.

No entanto, a expressão latina mais utilizada para transcrever o suicídio é mortem sibi consciscere. Vemo-la em autores tão díspares quanto Plauto, o historiador Cássio Hemina e em prescrições jurídicas em Roma ${ }^{5}$. O verbo consciscere é traduzido por 'decidir com conhecimento de causa'. Se associarmos este valor semântico a mortem sibi, deparamo-nos com a identificação do acto a uma decisão totalmente consciente e, atrevendo-nos desde já a ir mais longe, a uma decisão livre. ${ }^{6}$

Devido à estrutura modular, em lego, do grego, poder-se-ia pensar encontrar mais facilmente uma palavra que plasmasse ipsis verbis o conceito de suicídio. Van Hoof considera que authentes, autocheir e autophonos se reportam a um indivíduo que mata o seu próprio parente, alguém do seu sangue. No entanto, verificámos que os dicionários de grego também incluem, embora com menor intensidade e ênfase, a ideia de exercer violência sobre si próprio, embora mais geralmente sobre outrem. Concluise, por isso, que se trata de termos que não são específicos do suicídio.

Observando expressões que exprimam a vontade de empreender esse acto, destacamos hekousios thanatos, a morte voluntária, e o seu correspondente latino, mors voluntaria.

Aphistamai tou biou, o auto-afastamento da vida, é outro modo de veicular a noção de suicídio. Mas, a subtileza filosófica mais densa e talvez mais inquietante, reside na saída racional da vida (exagoge eulogos), com o seu equivalente latino

\footnotetext{
${ }^{3}$ Em Quaestio de suicidio, apud Grisé 198223.

${ }^{4}$ Apud Grisé 1982 22-28.

5 Apud Grisé 1982 24-25.

${ }^{6}$ A etimologia de consciscere relaciona-se com o verbo sciscere, e este com o verbo scire, que significa 'saber'.
} 
excessus e vita rationalis $^{7}$. Com efeito, é ultrapassado um degrau conceptual quando se passa da morte voluntária para a morte racional. E aqui, acabámos de determinar as pontas de um triângulo equilátero: morte voluntária, morte em consciência, morte racional.

Este breve caminho semântico percorrido faz ressaltar a ausência de nocividade na palavra suicídio, permitindo percepcionar desde já que as faces do suicídio no Mundo Antigo estariam pintadas de cores distintas das de épocas posteriores.

Durkheim, no século XIX (Le Suicide 1897) ${ }^{8}$, define genericamente duas situações conceptuais que conduzem ao suicídio: a insuficiente e deficiente integração no grupo social ou, pelo contrário, a desmedida integração e diminuta individualização. A primeira categoria é subdividida em suicídio egoísta, onde pauta a excessiva individualização, e suicídio anómico, onde a falta de regulação da sociedade sobre o indivíduo e a não identificação do indivíduo com essa sociedade o leva a um sentimento de alienação e de profunda insatisfação.

Na segunda categoria, encontramos o suicídio altruísta, de auto-sacrifício, palco de uma extrema identificação do indivíduo com o grupo, e o suicídio fatalista, resultado da elevada regulação da sociedade sobre o indivíduo e consequente castração dos desejos pessoais, como, por exemplo, nos casos de um indivíduo submetido à escravatura ou do casamento forçado de uma mulher criança.

Nas histórias mitológicas, a matéria sobre a qual estamos a trabalhar, essa definição do suicídio vivenciará um espectro enorme de reinterpretações, que vão do terrífico ao, diríamos, poético-filosófico. Estes mitos nascem também de um tempo muito alargado e somatizam em si características do ethos da Grécia e de Roma. No horror, deparámo-nos com vários casos de canibalismo, entre eles o de Cambles, que, sob o efeito de magia, fica possuído por uma fome demencial que o leva a comer tudo, inclusive a sua mulher. Nesse mesmo registo poético-filosófico, reencontramos o sábio centauro Quíron, que foi inadvertidamente atingido por uma das setas mortais de Héracles. Não conseguindo suportar a dor física, pedirá a Prometeu que lhe conceda um privilégio único dos homens: a mortalidade. Ele, em troca, dar-lhe-á a sua imortalidade. Neste exemplo é o homem que se transfigura em deus e o deus que fica homem. Estes dois exemplos já mostram que as narrativas mitológicas nos presenteiam com

\footnotetext{
${ }^{7}$ Seria Antístenes, aluno de Sócrates, quem criou este conceito. Ver Van Hoof 1990141.

8 Apud Hill 2004 4-5; Garrison 1991 2-4.
} 
percepções muito diferentes do suicídio. Essas diferenciações, por vezes abissais, por vezes ténues, são matéria de reflexão sobre o Mundo Antigo. 


\section{Organização do Corpus e sua Tipologia}

\section{Modus operandi para a recolha dos dados}

Comecemos por explicar a lógica construtiva do corpus, não hesitando em utilizar exemplos quando nos parecerem clarificadores da estrutura adoptada. Embora existam inevitáveis referências aos motivos do suicídio, estes serão objecto de análise sistemática e aprofundada posterior. Pretende-se, neste modus operandi, apontar o espectro das várias expressões de suicídio consideradas - desde as metamorfoses aos suicídios frustrados por intervenção alheia —, fazer sobressair alguns dos caminhos percorridos na imensa informação encontrada, e anotar inconsistências detectadas nos estudos efectuados e nos dicionários.

Na nossa pesquisa procurámos identificar todas as histórias onde existe suicídio nos mitónimos do Dictionnaire de la Mythologie Grecque et Romaine de Pierre Grimal, no pressuposto de que esse instrumento de trabalho seria praticamente a base única para a organização do corpus. Tendo verificado imprecisões, omissões e até erros, concluímos que era necessário recorrer a outros instrumentos. Assim, para além da consulta do Brill's New Pauly, impôs-se também pesquisar a Paulys Real Encyclopädie, para esclarecer dúvidas, confirmar ou aprofundar certos aspectos do relato. Sentimos também a necessidade de alargar a consulta de fontes primárias para deslindar algumas versões, nomeadamente aos trágicos gregos, a Pausânias, Virgílio, Ovídio, Higino e Séneca.

O enorme espaço cronológico a que as histórias se reportam, desde tempos minóicos à época romana, sem esquecer uma eventual matriz indo-europeia e os fortes e antigos contactos entre o Oriente e o Ocidente, particularmente por espaços 
mesopotâmicos e anatólicos, bem como a multiplicação de versões sobre o mesmo mitónimo, ao sabor local ou epocal, ou ao gosto de autores tão originais como os trágicos ou tão criativos como Ovídio, aplicaram a cada história por vezes um elevado número de variantes.

Em consequência, e para encontrarmos os padrões que procurávamos, tivemos que estabelecer critérios. Assim, quando detectámos versões com desfechos suicidas e não suicidas, apenas considerámos as primeiras. No caso de variações de pormenor, como por exemplo, o meio utilizado para o suicídio, optámos pela solução mais antiga ou mais generalizada. Por vezes, para o mesmo personagem, a narração contém versões distintas, conduzindo ao mesmo fim em causa. Nessas situações, registámos entradas diferentes, numerando cada versão. Em personagens distintos com o mesmo nome, adoptámos solução idêntica.

Incluímos no corpus os suicídios frustrados que não se concretizaram por intervenção de agentes exteriores. Veja-se por exemplo Hermíone, mulher de Neoptólemo. Tenta matar a todo o custo a que fora concubina do marido, Andrómaca, assim como o filho desta. Falha o projecto e, frustrada, tenta suicidar-se. Não concretiza apenas porque a ama e a criadagem intervêm. Também no Orestes de Eurípides a vontade do herói homónimo é várias vezes reiterada, ele chega mesmo a escolher a arma, mas o acto não acontece devido à intervenção divina.

Por vezes, aqueles que se matam, só materializam o propósito depois de várias tentativas frustradas, sendo este aliás um perfil muito usual nos suicídios reais. Nesta linha, a Fedra de Séneca dá-nos conta de uma primeira vontade de suicídio da heroína, dissuadida pela ama, que lhe diz: "Considero que tu mereces viver por isto, por tu mesma afirmares que mereces morrer" (vv. 255-7).

Nalguns casos, como o de Mirra 1, identificámos uma primeira tentativa frustrada, que se enquadraria no motivo pudor: tentaria matar-se porque se apaixonou por seu pai. Mas, a história desfecha-se num contexto de tédio da vida (taedium vitae): Mirra cansa-se da vida errante que leva, fugindo do pai que a quer matar e é, portanto, essa a opção que figura no corpus como motivo. Fica assim claro que tanto as tentativas falhadas como as bem sucedidas podem apresentar motivos distintos, decorrentes do contexto da história

No caso de Filoctetes, um dos pretendentes de Helena, depositário do arco e das flechas de Héracles e um dos heróis da Guerra de Tróia, não é referido suicídio nem em BNP, nem Grimal nem em RE. Além disso, a sua classificação em Van Hoof revela incoerência, se compararmos com a de Orestes. Para este último, Van Hoof discrimina 
três tentativas goradas. Ao invés, para Filoctetes, que entendemos não elencar no nosso corpus, apenas indica uma entrada, quando existem vários ensaios de suicídio relatados na obra homónima de Sófocles ${ }^{9}$.

As metamorfoses configuram também suicídio. O ser que existia dá lugar a um outro. Glauco atira-se ao mar e é transformado em deus marinho. As Helíades choram tanto à morte do irmão que são transformadas em choupos. A ninfa Sálmacis, apaixonada por Hermafrodito, pede aos deuses que não permitam que os seus corpos se separem. Então os deuses unem-nos, formando um novo ser, com natureza dupla. Entendemos ser esta metamorfose "a pedido" também uma expressão de suicídio. Muitas vezes, submetem-se a esta transformação personagens de origem divina ou semidivina. "Pensá-los mortais" passa a submeter-se ao crivo de "pensá-los metamorfoseados". Existe aqui uma compatibilização da ideia de suicídio com a ideia de imortalidade, à qual não será estranha a tentativa de racionalização tão intrinsecamente grega. Este padrão de intervenção divina, a metamorfose, na narrativa lendária é tão forte que nos atrevemos a encontrar um eco seu no motivo do deus ex machina da produção dramática ${ }^{10}$.

Como exemplo, destacamos Aracne. Num concurso entre esta e Atena, para se averiguar qual a melhor na arte da tecelagem, a deusa destrói o trabalho da rapariga, que se enforca. Todavia, a deusa, não a querendo ver morta, transforma-a em aranha. É como se esta outra vida, decorrente de uma metamorfose, fosse a promessa de uma certa tranquilidade.

Já Psâmate, uma Nereide, foge da perseguição de Éaco transformando-se em foca, mas sem sucesso. Ela metamorfoseia-se para fugir, não para sucumbir, e aqui, a transformação, que fazia parte dos atributos das Nereides, assume a face da sobrevivência, não da morte. Por isso Psâmate não foi inserida no corpus ${ }^{11}$.

Ocno também não foi elencado no corpus. Ocno é um velho que, cansado da vida, atira ao chão o fardo que carrega e impetra a morte. Quando ela chega, pede-lhe que lhe

\footnotetext{
${ }^{9}$ Ver: BNP s.v. Philoctetes 66-67 (não refere suicídio); Grimal s.v. Philoctète 367-369; RE s.v. Philoktetes 2500-2509; Sófocles, Filoctetes, As várias alusões de Filoctetes a suicídio afiguram-se mais chantagem do que verdadeiro propósito de suicídio: v.746-749 (num acesso de dor, pede a Neoptólemo que lhe corte um pé, que não lhe poupe a vida); 819-821 (em acesso de dor, pede à terra que o acolha); 1001-1002 (ameaça precipitar-se sobre rocha por ter sido traído); 1081-1162 (no final, a sua preocupação, mesmo despojado do arco, é garantir a subsistência e não se deixar morrer por inedia); 1204-1217 (pede que lhe dêem uma espada para se trespassar, já que fica abandonado).

${ }^{10}$ Ver o caso de Orestes, em Eurípides.

${ }^{11}$ BNP s.v. Psamathe 105-106; Grimal s.v. Psamathé 399-400; s.v. Phocos nº 3; RE s.v. Psamathe 1298-1303 n¹; Apolodoro, Biblioteca, 3.13 .6 (capacidade de se metamorfosear); Ovídio, Met. 11.346-406 (refere vingança, não suicídio).
} 
ponha novamente o fardo sobre as suas costas. Destacamos este exemplo pois é aquele que no final, não quis morrer. Entendemos que o testemunho desta experiência, pela sua antítese, ilumina melhor as múltiplas vivências do suicídio. A este propósito, dirá Esopo num tom anti-estóico, que "esta fábula mostra que todos os homens estão ligados à existência, mesmo se aí têm uma vida miserável"12.

Nalguns mitos cruzam-se caminhos diversos e coloridos, versões contraditórias que apenas atestam a enorme abundância cultural que transportam. Estes cruzamentos de lendas e registos por vezes folclóricos revelaram-se enriquecedores e exigiram uma procura sistemática nos diferentes dicionários e fontes para desatar os eventuais nós górdios surgidos. Por exemplo, para Adrasto estabelecemos três entradas. As duas primeiras são identificadas com o mesmo personagem, Adrasto, o rei de Argos, mas apresentam a morte do personagem de forma totalmente distinta. No primeiro caso ele mata-se por desgosto pela morte do filho. Classificámos o motivo como dolor e o meio utilizado foi indetectável na pesquisa das fontes e dos dicionários. No segundo caso, o suicídio está associado ao oráculo de Apolo, e Adrasto imola-se por devotio, ou seja, sacrifica-se pela comunidade. No terceiro caso, trata-se de um personagem diferente. É Adrasto, filho de Midas, que se degola por dolor, dor pela perda do amigo. Vemos portanto que, sob um mitónimo, podem-se ocultar múltiplos fios entrelaçados de histórias, interpretações e contextualizações muito variadas. A confrontação destes casos levou-nos sempre a um exercício de "separação de águas", de limpeza da nebulosidade das várias lendas, de forma a que o corpus se apresentasse claro e preciso nas suas opções.

Também o caso de Ocna ilustra um exercício de escolha. Para o modo de suicídio, Grimal dita o enforcamento, enquanto que Plutarco e RE optam pela precipitação. Neste caso, seguimos a versão que se afigurou mais popularizada, a precipitação.

Na desocultação das histórias detectámos incongruências em Van Hoof. Por exemplo, na lenda de Cila, esta atraiçoa seu pai, cortando-lhe o cabelo, fonte do seu poder $^{13}$. Van Hoof diz que é o seu próprio cabelo que ela corta. Além disso, a referência que põe das Fábulas de Higino, a 197.3, não existe. Em Hipónoo, existe referência à fábula 2 de Higino, mas trata-se da fábula 242.

\footnotetext{
12 Esopo, Fábula 78 "O Velho e a Morte"; cf. BNP s.v. Ocnus 17; Grimal s.v. Ocnos (não regista este mito); RE s.v. Oknos 2383-2385 (não é este mitónimo, mas existem algumas afinidades); [Van Hoof: não regista].

${ }^{13} \mathrm{O}$ simbolismo do cabelo mágico atravessa as histórias lendárias, como em Sansão.
} 
Confirmou-se que a tradução portuguesa do Grimal contém algumas imprecisões e ambiguidade de critérios. Por exemplo, Atamante conduz, no índice remissivo, a Átamas, mas não tem nenhuma entrada no dicionário, que deveria, naturalmente, existir e também remeter para Átamas. Também existe uma entrada Melete, que não está na versão original e que remete para a entrada Meles. Ora, nessa entrada, a variação que se apresenta em relação a Meles é Melito.

No aparato crítico discrimina-se o motivo (causa moriendi), o modo (modus moriendi), os temas sugeridos pela lenda que a nosso ver irrompem como os mais significativos, os dicionários consultados, eventuais fontes antigas e os resultados da pesquisa de Van Hoof. Houve sempre a preocupação de confrontarmos os nossos resultados com este autor, pois, tendo em conta a tipologia que procurou definir, foi esse o nosso ponto de partida.

A identificação de temáticas recorrentes nestes mitos é matéria para reflexão sobre contextos históricos e culturais. Por vezes, quando entendemos ser mais clarificador, apontámos pequenos excertos da pesquisa que justificam a opção tomada, sobretudo ao nível dos motivos. Estão também evidenciadas pequenas ou grandes variações na história que atestam os reptos surgidos para apresentar um corpus rico e esclarecedor, e que nos obrigou a um constante exercício dialéctico. Nas histórias descritas adoptámos aquilo a que Walter Burkert chamou de "seco resumo"14. É muitas vezes na depuração da realidade que emergem padrões históricos e sociológicos relevantes.

\section{Tipologia do Corpus}

\subsection{Motivos para o suicídio - causae moriendi}

Revelou-se muito desafiador caracterizar, dentro da tipologia do suicídio, os diferentes estados de espírito do indivíduo na altura do acto. Utilizámos como ponto de partida o estudo de Van Hoof. Mas, no âmbito da nossa análise, tivemos a necessidade de criar um paradigma específico.

\footnotetext{
${ }^{14}$ W. Burkert 19818
} 
Quando definimos esta tipologia psicológica, inserimo-la evidentemente dentro do contexto histórico antigo, procurando encontrar termos que façam parte desse caldo cultural passado. Corroboramos portanto Van Hoof quando diz que "é preferível tentar descrever motivações antigas com termos antigos" ${ }^{\prime 15}$. Nestas figuras seria impossível desocultar totalmente a realidade interior e ter uma visão de conjunto do edifício de vida específico que levou ao suicídio. Conceptualmente, pareceu-nos que o único caminho viável e frutuoso seria clarificar o motivo principal ou o mais imediato, o catalisador último da acção de auto-destruição. Para tal, não hesitámos em utilizar os casos do corpus para argumentar e exemplificar a "personalidade" de cada tipologia, calcorreando as suas áreas de influência e clarificando os limites de cada uma. Muitas vezes, o mais polémico foi distinguir lendas que, a nosso ver, integravam de forma expressiva características de várias tipologias. Procurámos nas fontes informação que nos fizesse definitivamente optar por determinada tipologia em detrimento de outras, procurando definir de forma inequívoca as classificações e alicerçando as escolhas efectuadas nos argumentos que nos pareceram mais válidos e estruturados. Estabelecemos comparações com outras situações similares, assinalando padrões comuns. Muitas vezes, a dúvidas levantadas numa história foram sendo esclarecidas com outras histórias, como se de um muro de pedra se tratasse e que encontrasse a sua coesão e solidez na sobreposição e junção de todas as pedras.

\subsubsection{Devotio}

É o suicídio altruísta. O indivíduo sacrifica a vida pela pátria, pela colectividade. Van Hoof distingue devotio de fides, a lealdade, que seria uma virtude dos de menor condição, como os escravos e as mulheres, aos olhos do amo, do marido. Neste caso, o suicídio da esposa, mais do que expressão de amor conjugal e dor, seria quase uma obrigação contratual da viúva em relação ao marido defunto. Ora nós excluímos todos estes exemplos de fides de Van Hoof, até por não podermos generalizar a ideia de inferioridade da mulher, que tinha, e usava, a capacidade de tomar a iniciativa do divórcio com o suporte da lei; pior nos parece equiparar a sua situação à dos escravos. Consideramos que esta tipologia só traria dúvidas especulativas e, sobretudo, mesmo

\footnotetext{
${ }^{15}$ V. Hoof 199082.
} 
com todos os dados que obtivemos sobre as histórias, não chegaríamos a conclusão válida e solidamente argumentada sobre como destrinçar, em muitas situações, entre dolor, devotio e fides. Fizemos então um levantamento dos casos que Van Hoof referenciou como fides e confrontámo-los com a nossa opção. Existe apenas um, Laodamia, que classificámos como dolor e que efectivamente se configura um caso típico desta tipologia, na variante amor conjugal.

Ao invés, o exemplo de Pílades, que quer morrer com Orestes, quando este é condenado, poderia representar um caso exemplar de fides, de lealdade. No entanto, pensamos ser mais incisivo classificá-lo como dolor e, neste caso, Van Hoof acompanha-nos. Nas situações em que se identificou sentimentos de lealdade e de amizade, expusemo-los nos temas de forma a que não ficassem apenas subentendidos na leitura do mito.

Ancuro e Codro representam ambos a clássica acção de devotio. Todas as peçaschave aí se encontram: o sacrifício para salvar a sua cidade, a intervenção de um oráculo que assim o determinou. Em Codro, o sacrifício completa-se mesmo com provocação ao inimigo. Aliás, este modus operandi, o desafio, é somente identificado em personagens masculinos e indicia, portanto, um agir mais contido no registo feminino ${ }^{16}$.

Alceste sacrifica-se pelo marido. A acção é de cunho político: o seu gesto ajudará a salvar a pátria pois é ele o rei. Deste modo, afastámo-nos definitivamente da opção dolor, variante amor conjugal, posicionando-o na tipologia devotio. Nesta óptica segue também Antíloco, com o cunho da provocação.

Entende Van Hoof que "devotio is a man's duty" excelência o oikos e o sacrifício pela colectividade, um atributo masculino. Nesta matéria, contestamos este resultado, pois o número de casos femininos é muito expressivo também ${ }^{18}$. Ora, fazendo o exercício de calcorrear o caminho entre o mundo dos mitos e o mundo real, acendem-se aqui luzes clarificadoras do papel também interventivo da mulher nas sociedades antigas.

\footnotetext{
${ }^{16}$ Contam-se sete casos de provocatio: Antíloco, Codro, Márato, Aquiles, Euquenor, Ídmon e Niso 2. Os três primeiros no enquadramento devotio, os três seguintes em necessitas e o quinto em dolor.

${ }^{17}$ Van Hoof 1990127.

${ }^{18}$ Contam-se nove casos de devotio feminina e treze de devotio masculina. Para uma visualização clara dos motivos por género, ver gráfico II. O total das entradas foi de duzentas e trinta e uma. Neste e nos outros gráficos onde discriminámos por género, não considerámos o povo Hiperbóreo e o cão Mera, aparecendo desta forma no título do gráfico $n=229$.
} 


\subsubsection{Taedium vitae}

Taedium vitae é a saciedade da vida ou o simples desgosto de viver. $\mathrm{Na}$ perspectiva positiva do tema da saciedade da vida, deparamo-nos com os Hiperbóreos e a ave Fénix. Nesta, morte e renascimento formam um par coeso e indissociável, ciclo contínuo de uma morte que gera nova vida. Nos Hiperbóreos, esta saciedade remete-nos para uma vivência pacífica e mesmo positiva do acto, reproduzindo os costumes dos massiliotas. Também aqui se esgrimem argumentos de feição estóica: existe uma legitimação pela razão, como ordem suprema da natureza, a qual não exclui o ir ao encontro da morte após uma longa existência. É enfatizada a liberdade moral de se optar pela morte se se entender que viver já não tem significado. Além disso, existe a valorização desta curiosa perspectiva: o suicídio no degrau máximo da felicidade, prova suprema de grande sabedoria e que não corre o nefasto perigo da Fortuna se reverter. A este propósito, Valério Máximo reporta o testemunho desta mulher: "Constantemente senti a fortuna favorável e, com medo de experimentar o seu rigor, por estar muito agarrada à vida, vou trocar os poucos dias que me restam por um fim feliz" ${ }^{\prime 19}$.

Em casos lendários, o pai pretende matar Mirra, mas ela foge. Acaba por se cansar da vida errante que leva e mata-se. Drímaco, o escravo que lidera a revolta dos da sua condição, também se cansa de uma vida de fuga e põe-lhe termo.

Assim, o taedium vitae assume duas vertentes: um fim por saciedade feliz da existência; ou, ao invés, um fim por desgostosa canseira da mesma. Estes dois argumentos são, aliás, legitimados numa abordagem estóica à temática. Liberdade moral de se optar pela morte se se entender que viver já não tem significado, e sabedoria do suicídio no degrau máximo da felicidade, de forma a não correr o perigo de a Fortuna se reverter. A este propósito, diz-nos Plutarco: "Quando um homem está na posse de todos os seus bens, quando nada do que é necessário à alegria e à felicidade lhe falta, é conveniente para esse homem deixar a vida" ${ }^{20}$.

\footnotetext{
${ }^{19}$ Apud Grisé 1982184.

${ }^{20}$ Plutarco, As Noções Comuns, apud Grisé 1982184.
} 


\subsubsection{Dolor}

Muito embora a palavra latina dolor possa também especificar sofrimento físico, no nosso paradigma reservámos esta situação para impatientia doloris, remetendo o sofrimento psíquico para a categoria dolor. É evidente que este termo é muito genérico e que, sob o manto das outras categorias, também encontramos o rasto da dor. Por isso, ao classificarmos um motivo como dolor, tivemos muitas vezes a necessidade de clarificar melhor o seu tipo. É a dor causada pela perda do marido, da mulher, do amante, de um filho, de um familiar, de um amigo ou mesmo de um animal e que até nos remete para sentimentos como a amizade, ou mesmo para relacionamentos como o homo-erotismo. Este sentimento configura-se também no amor não correspondido, ou desamor, como lhe chamámos. Esta situação está, aliás, muito bem definida em Pausânias, quando este diz que Selemno morre de amor ao ser abandonado pela ninfa Árgira ${ }^{21}$. Os exemplos abundam em todos os cambiantes possíveis e é por essa razão por encerrar em si um sentimento tão genérico e abrangente quanto o é a própria dor que este motivo revela ser o mais frequente ${ }^{22}$.

Vejamos alguns casos. Hilónome não quer sobreviver ao seu marido e mata-se com a mesma flecha que o havia trespassado. A pertença da arma acentua ainda mais o simbolismo do acto e estabelece, numa primeira abordagem, uma ligação com a fides, no sentido da lealdade conjugal. No entanto, tal como em devotio, onde se afigurou pertinente discutir a eventual inserção de fides, que, como demonstrámos, mostrou ser desajustada, em dolor reforçámos esse entendimento. A reflexão sobre o caso de Hilónome enfatiza dois argumentos: com os elementos em causa, seria maioritariamente difícil, senão mesmo impossível, determinar a ténue fronteira que separa o sentimento dolor, derivado do amor, do sentimento de fides, corolário da lealdade à palavra dada no contrato nupcial. Além de não constar desse contrato a obrigação de suicídio em caso de morte de cônjuge - e até se diria que a ideologia grega e romana tende, por exemplo com o estoicismo e com razões sociais, a desdramatizar a dor pela perda do cônjuge —, não faria sentido não estender esse motivo a amantes, noivos, relações homossexuais. Ou seja, adicionar esta cor aos motivos traria, ao invés de clarificação, especulações inférteis.

\footnotetext{
${ }^{21}$ Neste e em casos semelhantes, para evitar repetições, deve procurar-se a referência na entrada respectiva no corpus.

${ }^{22}$ Ver gráfico I.
} 
Dolor é mais preponderante nas mulheres do que nos homens ${ }^{23}$. Como este é um motivo muito abrangente, afigurou-se-nos essencial destrinçá-lo nas suas variantes. Os resultados deste tratamento mostraram-se surpreendentes na abundância de informação ${ }^{24}$.

Ressalta primeiro que, em termos globais, os motivos "mais fortes" para o suicídio por dolor são o amor conjugal e o amor maternal/paternal, não havendo nenhum caso de homo-erotismo feminino. Posto isto, observa-se que as mulheres, matando-se significativamente mais que os homens por dolor, como foi atrás referido, fazem-no sobretudo por desamor (o amor não correspondido), onde aliás existe a discrepância mais acentuada entre os géneros, e por amor conjugal. Paralelamente, o amor maternal é "mais forte" que o paternal, embora este também não deixe de ser expressivo.

Todos estes resultados, pequenos mosaicos de um puzzle complexo e muito colorido, mostram indubitavelmente atitudes e móbiles diferentes no que concerne as personagens femininas versus masculinas. A discussão sobre estas diferenças leva-nos longe em contextos psicológicos e culturais.

\subsubsection{Desperata salus}

Na proposta de Van Hoof ${ }^{25}$, a desperata salus é a reacção súbita de dor perante a morte de um ente querido. Não existe o tempo do luto, esse é remetido para dolor. Não partilhamos deste entendimento do termo, pois esta lógica é muito difícil de definir com a matéria-prima de que dispomos. É mais claro caracterizar essas situações como dolor e reservar a desperata salus para o desespero agudo, induzido por não existir alternativa possível a uma situação. Por exemplo, os casos de virgens assediadas que, tentando fugir, não o conseguem e acabam por se matar para não ceder. Astéria foge de Zeus, que se enamorou dela, metamorfoseando-se em cordoniz para lhe escapar, mas, sem o conseguir, acaba por se atirar ao $\operatorname{mar}^{26}$.

\footnotetext{
${ }^{23}$ Ver gráfico II.

${ }^{24}$ Ver gráfico III.

${ }^{25}$ Van Hoof 1990100.

${ }^{26}$ Neste caso, a metamorfose não é suicídio, mas sim tentativa de sobrevivência e de fuga. O suicídio acontece posteriormente com a precipitação ao mar.
} 
Em contexto de desperata salus, nenhuma saída existe. Os Eginetas vêem-se sujeitos a uma peste terrível e muitos se enforcam. As duas irmãs, Molpadia e Parténope, não guardam bem o vinho que seu pai lhes havia confiado e, com medo do castigo, precipitam-se ao mar. O mal, que de forma iminente vai desaguar sobre os indefesos, também pode assumir-se como injúria grave. No caso de Hécuba, a cativa atira-se borda fora do barco, para não servir Ulisses. No entanto, aqui utilizámos a tipologia pudor, pois ela recusava-se a ficar sob o jugo do herói, Ulisses. Se fosse outro que não o herói de Ítaca, talvez não tivesse tomado a atitude de se matar, como parece deduzir-se de Séneca, Troianas, 989-990: "É do senhor que tenho vergonha, não da escravidão".

\subsubsection{Pudor}

Em pudor existe o sentimento de destruição da própria imagem, o medo de perder a face, a vergonha. Esta consciencialização é muito forte na Antiguidade. Veja-se o caso emblemático de Ájax. Na primeira versão da história, em Ájax 1, o herói suicidase depois de lhe ter sido recusado o Paládio e gorado o seu desejo de ver punida Helena com a pena de morte. Ájax consubstancia a imagem do guerreiro, da moralidade tradicional, como a de Aquiles ao entrar na guerra para vingar o amigo Pátroclo, mas vem a sofrer a humilhação extrema. Com efeito, as armas de Aquiles seriam destinadas ao mais ousado dos gregos, aquele que mais terror teria inspirado nos troianos. Quando interrogados os prisioneiros troianos sobre o facto, estes deliberam que foi Ulisses o mais destemido, e não Ájax. E, nessa mesma noite, Ájax enlouquece, tendo o fim que se lhe conhece. Neste "pudor ajaxiano" urde-se a humilhação, a perda de auto-estima, o desmoronar catastrófico de uma identificação com a sua própria imagem. Garrison ${ }^{27}$ vai mais longe ao afirmar que o suicídio de Ájax pode ser interpretado como uma tentativa em manter as especificidades da sociedade heróica, também evidenciando o que acontece ao indivíduo quando estas características estão em modificação e ele não as aceita. Com o seu gesto, Ájax nega os valores emergentes e mostra a sua desadaptação à sociedade. Nesta argumentação, o Paládio é atribuído a Ulisses devido à sua eloquência, mostrando que os seus pares aceitam uma nova sociedade, na qual a retórica é

\footnotetext{
${ }^{27}$ Garrison 1991 1-34.
} 
percepcionada como sendo mais digna de prémio que o poder militar, uma sociedade onde a arete marcial não tem a primazia sobre o resto. Este raciocínio é equívoco, a nosso ver, pois Ulisses também faz prova de grande intervenção bélica. No entanto, tal interpretação também conflui no sentido primordial do termo pudor: ele é o marco distintivo da dicotomia vergonha/honra, tão cara ao pensamento grego. Ao matar-se, Ájax reencontra o seu ethos de guerreiro, reconstrói a sua imagem, reconcilia-se com os deuses e a sociedade, é resgatado da cobardia e da humilhação.

Este desagregar da imagem, que é o cunho de pudor, manifesta-se em diversos contextos. Identificámos a perda de influência política, motivo eminentemente masculino, recolhido no exemplo de Ágrio, deposto e expulso do poder; ou então, em Briseu, que assiste à destruição do reino. Identificamo-la na frustração de ver gorada uma vontade sua, como em Ânio ou Eveno; ou quando existe destruição daquilo que seria mais valorizável na personalidade do indivíduo. Esta situação remete-nos para o adivinho Calcas, que é quem sugere a construção do cavalo de Tróia e é ultrapassado numa competição por Mopso.

No exemplo de Nicteu, identificámos pudor em dois aspectos: na vergonha que sente pela filha e na impotência em conseguir castigá-la. É interessante atermo-nos à expressão que Apolodoro emprega a este propósito: "Sentindo-se desencorajado, matou-se". Ou seja, Nicteu, deprimido, mata-se. Este desânimo, este abatimento urde-se nas teias do pudor, catalisador de sentimentos de baixa auto-estima e de fragmentação da própria imagem. Isto também é muito claro na motivação de Aracne para o suicídio: Atena desmereceu o seu trabalho, motivo de orgulho, destruindo-o.

Em Cárila, escorrem do pudor as lágrimas da impotência. A lenda também realça a imagem da mulher interventiva, actuante na sociedade, e é coerente com a realidade já expressa anteriormente da importância do motivo da devotio feminina ${ }^{28}$.

Também Lucrécia, sublimação da pudicitia, tem um papel interventivo na sociedade. A sua atitude terá consequências políticas profundas, desencadeando a queda da monarquia, em Roma, e o nascimento da república. Ela interpreta, a um tempo, a castidade feminina, a vivência da família, o espaço do recolhimento, todos eles pedras basilares do bem-estar social, e a outro, o símbolo, o motor catalisador da grande convulsão política e social. Na congregação destes dois factores, a sua importância é tal, que se fixa como arquétipo na Roma Antiga.

\footnotetext{
${ }^{28}$ Vide nota 18 do presente estudo.
} 
Analisando o que levou à classificação em pudor, tal como fizemos para dolor, evidenciam-se dois aspectos muito interessantes. O primeiro é o de que este sentimento é maioritariamente derivado de sevícias e assédios sexuais, assim como da vergonha por actos cometidos de forma consciente ou inconsciente em ligações tabu. Desta forma, reencontramos pudor, no registo masculino, em Cíniras1 e Ganges, reis que violam as filhas sem o saber. $\mathrm{O}$ delito foi cometido de forma inconsciente, mas isso não apaga a mancha criada. O segundo aspecto é, a nosso ver, bastante inesperado. À luz de uma moral sexual desde sempre mais repressiva para as mulheres, assim como da sua posição mais frágil nas sociedades: esta causa é mais expressiva nos homens do que nas mulheres $^{29}$.

\subsubsection{Conscientia}

Em conscientia explicitam-se os remorsos e o arrependimento por um acto cometido. Uma das dificuldades que sentimos muitas vezes foi averiguar da justeza da atribuição de conscientia ou pudor. Por exemplo, Eufrates mata o filho pensando tratarse de um estrangeiro com o qual a sua mulher estaria a praticar adultério. Legalmente, Eufrates teria toda a legitimidade em matar os dois, a sua acção não foi delituosa. Fazendo apelo às leis de Sólon, através de Plutarco: "Concedeu ... que matasse um adúltero a quem o apanhasse (em flagrante)". Portanto, alicerçados também pelo concreto da realidade, quando se dá o reconhecimento dos protagonistas, considerámos como a opção mais válida a tipologia dolor, dor pela morte do filho, em detrimento de conscientia. Eufrates não teria nada de que se culpabilizar, e em prejuízo também de pudor, ele não teria nada de que se envergonhar. Invocámos este exemplo de dolor por fazer emergir de forma clara a dicotomia entre conscientia e pudor. Este raciocínio aplica-se igualmente à situação idêntica de Altémenes, que mata o pai sem o reconhecer. Mais uma vez, reportando-nos às leis de Sólon, na voz de Demóstenes, reencontramos o mesmo filão desculpabilizante desta acção ${ }^{30}$ :

Se alguém comete um homicídio sem intenção durante os jogos ou abate (um atacante) na estrada ou na guerra, por engano, ou (ao apanhar um adúltero em flagrante) com a esposa

\footnotetext{
${ }^{29}$ Contam-se $9 \%$ de casos masculinos e $7 \%$ de casos femininos.

${ }^{30}$ F 20 R (Demóstenes, 23.43) apud D. Leão 2001349.
} 
ou com a mãe ou com a irmã ou com a filha ou com a concubina, que tomara para ter filhos livres, em casos destes o homicida não será exilado.

Nestes dois casos, de Eufrates e de Altémenes, as leis de Sólon permitiram-nos consolidar os argumentos para não os classificar em conscientia ou mesmo pudor. $\mathrm{Ou}$ seja, à luz da lei, este tipo de homicida estaria inocentado das acções cometidas. Em consequência, valorizámos dolor como motivo do suicídio.

Classificámos Dejanira em conscientia, pois é ela quem aplica o filtro na veste de Héracles. E, muito embora pense tratar-se de um filtro de amor, a magia está sempre ligada a algo nocivo, que vai contra a natureza, e disso ela teria a noção.

Fazendo fé no BNP, "Fedra suicida-se quando o seu amor por Hipólito se torna público". Na observância deste apontamento, remeteríamos para pudor este acto, seria a vergonha do sentimento tornado público. Mas na Fedra de Séneca é patente o motivo por conscientia. Diz a heroína (vv. 1188-1200):

Ó morte, único alívio do amor perverso, (...) Contei coisas falsas e, ao mentir, culpei-o da atrocidade que eu própria, tresloucada, concebera no meu coração insano. Puniste-o em vão, pai $(\ldots)$

É um verdadeiro acto de contrição, aquele que se estende sob o nosso olhar, onde a conscientia encontra palco.

Na lenda de Hermíone, esta também sabe que cometeu um delito objectivo, tem consciência de que o fez, tentou matar a concubina do marido e o seu filho.

É inevitável associar-se a conscientia à cultura da culpa, do pecado interior, e o pudor à cultura da vergonha, da destruição da imagem perante o exterior, perante a colectividade $^{31}$. Aqui, existe uma culpa objectiva e concreta que se distingue da culpa subjectiva de pudor $^{32}$ e, nesse exercício, vimos que o repto maior, lançado sobre esta tipologia, foi a distinção entre conscientia e pudor.

\footnotetext{
${ }^{31}$ Vide E. Dodds 198826 36-37 e 56-61. Este autor atribui a cultura da vergonha ("shame culture") à época homérica e a cultura da culpa ("guilt culture") à cultura arcaica; J. T. Hooker 1987 121-125.

${ }^{32}$ A nosso ver, esta distinção não explica porque é que, enquanto que o pudor masculino ultrapassa um pouco o pudor feminino, nas situações de conscientia os casos femininos são em número muito superior aos masculinos (gráfico II).
} 


\subsubsection{Furor}

A loucura cognomina-se de mania para os gregos e de amentia, dementia, furor, insania, para os romanos. Em furor congregámos o delírio, a insanidade, a paixão irracional $^{33}$. Em muitos exemplos, esse furor é transmitido pelos deuses como punição. Veja-se o caso de Átis, que prometera a Cíbele manter a virgindade mas que se apaixona por uma ninfa. Cíbele provoca-lhe então a loucura e Átis castra-se. Noutra lenda, Corónis, a ama de Dioniso, é entregue a Butes. O deus enlouquece-o e ele atira-se a um poço ${ }^{34}$.

É sabido que os deuses castigam a desmedida. Erisícton incorreu em hybris e será punitivamente transformado em pantófago, até acabar por se devorar a ele próprio, num acto de loucura e auto-destruição.

O furor também pode provir do pavor. Seres híbridos, como as Erínias, induzem comportamentos psicóticos. Identificámos Helena, tão atormentada por elas que acaba por se matar. No mito das filhas de Cécrops, estas, ao verem provavelmente um bebé com cauda de serpente, também enlouquecem.

Identifica-se igualmente furor nos estados compulsivos, maníacos e no pathos, a paixão excessiva, como em Leucocomante, que protagoniza o ciúme anormal. $O$ narcisismo também se define e alimenta-se a si próprio de um estado maníaco e compulsivo. Reencontramos igualmente este patamar no sadomasoquismo da dupla Mele 1 / Timágoras 1. O amante masoquista e o amado sádico configuram ambos o critério de loucura $^{35}$.

Ájax 2 massacra os rebanhos gregos, pensando tratar-se do exército inimigo. Quando cai em si, suicida-se. Recorremos a este exemplo pois os momentos de lucidez não obliteram a tipificação em furor, antes fazem também parte do processo de distúrbio mental. Por essa mesma razão, em Alcínoe 1, classificamos de furor e não de conscientia, contradizendo Van Hoof. Enlouquecida por Atena, a personagem abandona a família para seguir um estrangeiro. Quando se apercebe do que fez, atira-se ao mar.

\footnotetext{
${ }^{33} \mathrm{Na}$ elaboração das tipologias do corpus, temos feito algumas observações que se reportam directamente ao estoicismo, pois a sua presença ajuda a definir algumas categorias. Mas, em furor, não poderíamos estar mais longe dos actos pautados por uma específica racionalidade.

34 Aliás, bastará pensar-se nas Bacantes de Eurípides para que Dioniso apareça cmo indutor por excelência do furor.

${ }_{35}$ Ao par Meles 1 / Timágoras 1, adiciona - se o par Meles 2 / Timágoras 2. Os papéis são invertidos e as histórias sofrem pouca diferença. No entanto, nestes quatro personagens, Meles 2 é o único que não é tipificado com furor, mas sim com desperata salus. Da interpretação da história, decorre este entendimento.
} 
Nitidamente, o furor antecede a lucidez e, portanto, integra-se totalmente no contexto da demência.

\subsubsection{Impatientia doloris}

Impatientia doloris somatiza a dor física. A túnica de Héracles dilacera-lhe a pele. Dejanira, sua mulher, havia-lhe aplicado uma poção fatal, pensando trata-se de um filtro de amor. O sofrimento revela-se intolerável para o herói, que assim se lança na morte. Quíron, já aqui referido, também não aguenta a dor dilacerante da seta envenenada de Herácles. Estes dois exemplos são eloquentes desta tipologia e, além disso, o estoicismo identifica-se neste motivo especificamente físico. Séneca, na sua juventude, sofre de tuberculose. Escreverá ao amigo fictício Lucílio:

Mas por fim fui-me abaixo, e cheguei ao ponto de ficar quase tuberculoso e reduzido a uma extrema magreza. Muitas vezes senti vontade de pôr termo à vida. O que me reteve foi a idade avançada do meu querido pai", ${ }^{36}$

Para o estóico romano, viver em serenidade e sabedoria será sem dúvida tarefa impossível. No comentário que faz ao Fédon, Olimpiodoro dirá que se legitimiza o suicídio quando "o corpo está sujeito a doenças incuráveis que o impedem de servir de instrumento à alma"37.

\subsubsection{Necessitas}

Necessitas é o suicídio por ordem de outrem. Em Roma, os suicídios a mando de alguém, por exemplo, do imperador, não eram assumidos na lei. Os historiadores usaram algumas expressões eufemísticas para estes suicídios forçados, e uma delas foi necessitas (necessidade). Neste caso, não se tratava de uma morte decorrente de uma opção voluntária inicial, mas sim de uma acção imposta por circunstância exterior com poder coercivo. O meio, esse sim, é que poderia ser, eventualmente, de escolha livre.

\footnotetext{
${ }^{36}$ Cartas a Lucílio, 70.16 (trad. de J. A. Segurado e Campos, Lúcio Aneu Séneca, Cartas a Lucílio. Lisboa, 1991).

${ }^{37}$ Apud Grisé 182.
} 
Necessitas tem, no entanto, duas diferenciações. A necessitas explícita é a ordem inequívoca dada para alguém se matar. Por exemplo, Cânace tem um filho do seu irmão e o pai ordena-lhe que se mate, sublinhando a ordem com o envio de espada. Orestes é também condenado à morte, muito embora possa escolher o meio, tal como Éson, subjugado à vontade do seu meio-irmão Pélias.

A outra distinção de necessitas é mais subjectiva: é a necessitas implícita. Elencámos neste domínio mais subjectivo as situações em que existe conhecimento de um oráculo que anuncia a morte se o personagem optar por determinada alternativa que o leve a esse fim. Por exemplo, Aquiles decide regressar ao combate depois da morte de Pátroclo. Já havia existência de um oráculo a predizer a sua morte em Tróia e, além disso, o seu cavalo Xanto, assim como Heitor e Tétis, dizem-lhe que o seu fim está próximo. Existe em Aquiles uma aceitação e procura do caminho que o conduzirá à morte, anunciada à partida. Nesta contextualização, entendemos pois ser o motivo necessitas.O mesmo se passa com o adivinho Ídmon, que embarca na expedição dos Argonautas, mesmo sabendo que morrerá.

Em necessitas, o protagonista também pode apenas antecipar-se a uma condenação já existente. Por exemplo, Antígona é encerrada viva, mas antecipa-se ao desfecho certo e enforca-se ${ }^{38}$. Noutro caso, Indo violou a filha do rei e, para evitar o castigo, que seria a morte, eventualmente o exílio, a escravatura, ou a prisão e tortura, antecipa-se a ela, atirando-se ao rio. Também Euquenor opta por partir para a guerra, sabendo que tanto ir como ficar em casa conduzirão irremediavelmente as duas ao mesmo destino. O personagem apenas faz a escolha entre os dois caminhos com fim fatal. Neste contexto, poderíamos especular que opta por aquele que mais glória, que mais iactatio lhe trará.

Desvenda-se pois necessitas no comando explícito, na antecipação a uma condenação, na obediência a um oráculo que prediz a morte. Observámos também que o peso de necessitas é superior nos homens ${ }^{39}$. A interrogação paira sobre se esta tipologia não remete, de forma natural, para uma maior intervenção, um maior protagonismo na sociedade e, por isso, a uma maior identificação com personagens masculinos. Tal facto

\footnotetext{
${ }^{38}$ É evidente que também podemos identificar nesta sua atitude a desobediência e independência em relação a Creonte, ao mesmo tempo que afirma a sua negação e isolamento, tal como Ajax, da sociedade.

${ }^{39}$ Contam-se sete casos de necessitas masculinos e dois femininos (ver gráfico II). É de realçar que a necessitas explícita conta com seis personagens e a necessitas implícita com quatro. Esta última é constituída por quatro personagens masculinos, Aquiles, Euquenor, Ídmon e Indo e apenas um feminino, Antígona 1. Os três primeiros personagens masculinos congregados em necessitas implícita, é-lhes associada a provocatio. Vide nota 16 do presente estudo.
} 
entra em contradição com outros já apontados, como a expressividade da devotio feminina e a importância de crimes sexuais masculinos no pudor. Mas os fios condutores que tecem a História urdem-se sempre em muitas realidades por vezes contraditórias entre si.

\subsubsection{Exsecratio}

Exsecratio é o suicídio por vingança, por desejo de trazer uma praga a um país ou a um indivíduo. Está associada a poderes mágicos e é, por vezes, a arma dos fracos. Veja-se Escédaso, que, sendo as filhas violadas por dois lacedemónios, mata-se, invocando as Erínias e lançando maldições sobre Esparta. No exemplo de Amínias, quando se mata frente à casa do amado Narciso, fá-lo lançando também imprecações contra este. Aqui, salienta-se uma identificação muito forte entre o suicida e aquele que ele odeia / ama, querendo desencadear neste sentimentos de culpabilidade.

É evidente que por detrás da exsecratio se podem resguardar causas diversas. Por exemplo, é o desamor de Narciso que catalisa as acções de Amínias, tal como em Fílis, que esperou em vão pelo seu amado. Melisso quer causar a revolta dos Coríntios para que estes o vinguem de Árquias, que havia provocado a morte de seu filho. O seu suicídio está também ligado à iactatio, a jactância. É uma morte encenada, em que o momento e o local escolhidos - na altura dos jogos Ístmicos e no templo de Posídon permitem ter uma teatralização com vista a causar mais impacto.

Quando se descobre que Evópis ama o irmão, estando casada com o tio, ela enforca-se. Neste personagem, tal como em Escédaso, também se perfila o pudor.

Vemos que nesta tipologia entrecruzam-se muito claramente algumas das outras tipologias, sendo a mais significativa dolor, o que é coerente com o facto de ser a classificação mais importante de todas. 


\subsubsection{Iactatio}

Nos últimos tempos da República e durante a dinastia Júlio-Cláudia, a elite romana cultiva o suicídio de uma forma exacerbadamente teatral e pública. É a romana mors, um mito moderno nascido dessas mortes dramáticas ${ }^{40}$.

Enquanto que, dos nossos dias, visionamos o acto como patológico e eminentemente privado, nas fontes romanas identificamos racionalidade (por exemplo, na perspectiva estóica). A iactatio contempla uma exibição da morte vivenciada de forma filosófica. É como se a comunhão com outros, desses derradeiros momentos, pudesse, de alguma forma, enriquecer e fazer reflectir quem assiste. A este propósito, invoque-se a célebre morte de Petrónio, que, tendo caído em desgraça perante Nero, é obrigado a suicidar-se numa típica acção de necessitas. Mas, a descrição que dela faz Tácito $^{41}$, toca-nos profundamente pela independência moral, desprendimento da vida e partilha da experiência, pois até de um banquete participa, mesmo após ter cortado as veias, voltado a fechá-las e a reabri-las novamente.

Enquadramos também o suicídio político de Séneca em necessitas. Mas quando os amigos choram a sua morte iminente, ele interroga-se: "Mas para onde é que foi a filosofia deles?" ${ }^{42}$, o que nos remete para uma serenidade estóica à qual não é alheia a iactatio.

No corpus, identificámos iactatio em Cidipe e em Glauco. Neste, muito embora exista a marca do furor, considerámos que, tendo-se tornado o suicídio público, o factor ostentação prevalece. Em Cidipe, numa leitura superficial da história, poder-se-ia correr o risco de interpretar a sua morte como dolor pela perda dos filhos. Mas Cidipe indaga junto de Hera o que é melhor para os filhos e eles adormecem no templo, não mais voltando à vida. E é Higino quem afirma que Cidipe, tendo procurado saber o que é melhor para os mortais, se mata. Reconhecemos nesta atitude a ostentação filosófica, de aceitação da morte e de procura da felicidade.

No caso de Melisso, prevaleceu a opção excecratio, no entanto a iactatio é referida nos temas. Entendemos, em Licurgo 1, ao contrário de Van Hoof, que caracteriza o motivo em iactatio, qualificá-lo de devotio, pois o seu não retorno a Atenas, decorrente do seu suicídio, assegurará a manutenção da constituição correcta na

\footnotetext{
${ }^{40}$ T. Hill 20041.

${ }^{41}$ Tácito, Anais, 16.18-20.2, apud D. Leão (2005), Petrónio: Satyricon. Lisboa, Cotovia, Introdução, p.20.

${ }^{42}$ Griffin 198665.
} 
cidade. Em Timágoras 1, também não partilhamos da opção iactatio de Van Hoof. Classificámos em furor, salientando o servitium amoris como temática emergente.

Iactatio apresenta-se como uma tipologia refinada, no sentido em que pressupõe uma certa serenidade filosófica. Desta forma, distância-se de tipologias onde os sentimentos humanos se expõem de forma mais violenta e exarcebada, tal com em dolor ou desperata salus. Neste argumento, pode-se encontrar a justificação para ser a mais rara classificação.

\subsection{Modos para o suicídio - modi moriendi}

$\mathrm{Na}$ exposição dos modi moriendi, apresentamos uma estrutura distinta da utilizada nos motivos. Optámos por não os separar, tal como havíamos feito nos motivos, antes desvendando a temática como um todo. Na nossa perspectiva, organizar desta forma a tipologia dos meios utilizados, afigurou-se-nos ser uma forma mais natural, mais coesa e mais viva, mas não menos clarificadora e assertiva. Tal facto devese ao seguinte: a construção da tipologia causae moriendi conduziu-nos a dois níveis de abstracção. O primeiro concentrou-se na conceptualização das diferentes classificações em causa; o segundo, na sua aplicação, alicerçada num raciocínio dedutivo, aos personagens míticos analisados. Ora, no caso dos modos utilizados para o suicídio, a informação colhe-se de uma forma mais directa nas fontes. Nos casos mais difíceis, advém por comparação ou dedução de mitos em contextos similares, conforme exemplificaremos mais à frente. No entanto, estamos perante um nível de abstracção menos complexo ao nível das tipologias, sobretudo da sua génese.

Enunciamos os modos encontrados para a concretização do suicídio segundo a ordem pela qual serão referidos: inedia, imolação, envenenamento, enforcamento, precipitação, afogamento e recurso a arma.

De entre estes meios utilizados, existe um que prima pela singularidade: a inedia ou seja, a abstinência alimentar. Um meio peculiar, o único que se prolonga no tempo e que leva paulatinamente o personagem a um extremo esquecimento de si próprio e a uma focalização intensa e desmesurada no objecto da sua preocupação. Por exemplo, Cálamo definha com a perda do amado, até se transformar numa cana. Eco, rejeitada por Narciso 1, também enfraquece e fica reduzida a uma voz plangente. Nestes dois casos, identificamos também um padrão recorrente na inedia, a metamorfose e o 
definhamento consequente. É como se este distanciamento convicto do corpo conduzisse inexoravelmente a uma transformação dessa própria matéria, que renasceria noutro ser.

Em Narciso 1, este meio assume mesmo uma tonalidade única: Narciso definha porque se apaixona por si próprio e fica preso à visão da sua imagem, esquecido de tudo. Não é a dor que acompanha a inedia, mas sim a alheação, quase diríamos, a alienação e, neste sentido, a demência, o furor.

Erisícton protagoniza o único caso de auto-consumição. A loucura leva-o a ser pantófago, até que o término é devorar-se. O seu olhar é pesadamente e desequilibradamente carnal para dentro de si próprio e ditará um desaparecimento do corpo. Considerámos pois a sua tipologia pertença da inedia. A este propósito, veja-se o depoimento do vigésimo mineiro, Richard Godoy Villaroel, que saiu da mina de São José no Chile, apôs mais de dois meses de enclausuramento, juntamente com trinta e dois companheiros, a setecentos metros de profundidade. $\mathrm{O}$ seu testemunho encerra, de forma muito eloquente, uma clara definição da inedia: "Estávamos à espera da morte. $O$ nosso corpo consumia-se a si próprio - estávamos tão magros" $"$.

Neste vivenciar a inedia, o corpo não definha de forma contínua, como acontece em Eco, pelo contrário, o seu desaparecimento faz-se aos solavancos, ao ritmo das dentadas, e portanto de forma descontínua ${ }^{44}$. E, nesta morte, podemos também surpreender o pecado da gula e certamente a reprovação de algum olhar estóico espreitando, e que sabe que os vícios, por natureza, se agravam e levam à autodestruição.

As mulheres que se matam por imolação, lançando-se para a pira do marido ${ }^{45}$, reflectem a influência da base indo-europeia nas lendas. Os deuses castigam a hybris de Capaneu e a sua mulher, Evadne, lança-se à pira. Exorbita-se o amor e a fidelidade conjugal. Além do mais, revela-se também o domínio do fogo e, por conseguinte, o domínio da metalurgia, que remonta ao segundo milénio, pequenos indícios que apontam a imensa amplitude temporal destes mitos.

Noutro registo, a imolação de Fénix diferencia-se das outras pelo seu carácter de continuidade, de imortalidade e até de felicidade, no seu perpétuo renascimento.

\footnotetext{
${ }^{43}$ Diário de Notícias, versão electrónica de 15 de Outubro de 2010.

44 Esta descontinuidade pode ser comparada à Física Quântica. Nesta teoria, observa-se que algumas quantidades físicas, como por exemplo a energia de um electrão que gravite à volta do núcleo de um átomo, só pode ser modificada através de quantidades discretas de energia, os quanta, múltiplos de uma constante física da natureza, a constante de Planck, não podendo essa quantidade ser modificada de forma contínua.

${ }^{45}$ Encontrámos também um caso masculino idêntico a esta situação, Cianipo 2.
} 
O suicídio por envenenamento é o método mais raro, conta-se apenas um caso, Éson, que bebe sangue de touro. Esta via intervém também de forma indirecta na morte de Héracles, pois a sua dor física extrema decorre da túnica envenenada que Dejanira lhe havia dado. A escassez dos resultados anula sequer a averiguação de uma possível tendência mais feminina ou mais masculina do método. No entanto, ele apresentou-senos mais helénico do que romano na sua identidade. Em Atenas existiam execuções por envenenamento, vide Sócrates, e esta percepção foi corroborada no estudo de Van Hoof para personagens reais ${ }^{46}$.

É inequívoco que este modo dependeria de uma medicina mais ou menos sofisticada. Grisé invoca Séneca para afirmar que os romanos conheciam a injecção subcutânea ${ }^{47}$. Desabafa o filósofo nas suas epístolas: "Não preciso rasgar todo o peito numa imensa ferida: um bisturi chega para abrir o caminho à suprema liberdade, um ponto diminuto do nosso corpo basta para nos garantir a segurança" ${ }^{\text {"48. }}$.

No modo enforcamento salienta-se a maior diferença entre os géneros ${ }^{49}$. Grisé diz-nos que este suicídio "parece ter sido uma das formas tradicionais de suicídio nas classes inferiores da sociedade romana" ${ }^{\text {"50 }}$. Este apontamento abre janela a uma reflexão mais abrangente: na esfera mítica, os suicídios são específicos das classes elevadas.

Ao especificar precipitação ${ }^{51}$, o nosso critério foi a queda sobre superfície sólida. No caso de queda sobre a água, mar ou rio, para a distinguir da precipitação, classificámos como afogamento.

Um caso emblemático de precipitação é o de Níobe. Depois de seu pai lhe matar os filhos, atira-se do alto da falésia e a lenda diz-nos que é transformada em pedra. É clarividente a imagem de desmembramento do corpo sobre a rocha, a que corresponde a ideia de se tornar pedra. Se recordarmos o destino por excelência de criminosos e traidores em Roma, a Rocha Trapeia, podemos considerar a precipitação como um dos meios mais violentos e desonrosos.

\footnotetext{
${ }^{46}$ Van Hoof 199060.

${ }^{47}$ Grisé 1982111.

${ }^{48}$ Cartas a Lucílio, 70.16 (trad. de J. A. Segurado e Campos, Lúcio Aneu Séneca, Cartas a Lucílio. Lisboa, 1991).

${ }^{49}$ Gráfico VI.

${ }^{50}$ Grisé 1982111.

${ }^{51} \mathrm{O}$ desenredar da lenda de Melicertes (ver Ino 1 e 2), detectou erro no estudo de Van Hoof. O autor diz que este se mata, precipitando-se ao mar. No entanto, verifica-se que se trata de um homicídio, a criança cai ao mar, com a mãe, mas já está morta ou, ainda viva, é arrastada pela progenitora. Ver Grimal s.v. Athamas 5657; s.v. Lélex 257-258; s.v. Leucothée 262; s.v. Mélicerte 287; s.v. Palameon 336-337; Higino, Fábulas, 2.5 , 4; [Van Hoof s.v. Melikertes:?, jumping, +, Hyg. Fab. 243.1].
} 
O afogamento é o modo mais numeroso ${ }^{52}$. Nesta quantidade tão elevada reconhecemos a importância da geografia grega, assim como a de todo o Mediterrâneo na formação identitária dos mitos. Ilhas e sobretudo o mar e os rios são palcos constantes das histórias. Desta forma, a água sobressai como um elemento muito presente e, de forma espontânea, é um catalisador por excelência do suicídio mítico. Esta forte correlação entre a água e estes mitos ainda é mais acentuada ao identificar-se que o modo de suicídio mais expressivo nos mitos mais numerosos, os epónimos e os etiológicos, é precisamente esse, o afogamento. ${ }^{53}$

No entanto, a par da importância fulcral deste modo, também identificamos um número semelhante de suicídios por arma. Os dois meios somam a quase metade (49\%) dos modos detectados. Com efeito, sob este termo genérico, a arma, engloba-se, o cutelo sacrificial, a espada e a arma de ferro. Vários contextos foram analisados e, nalguns casos, optou-se por fixar esta tipologia com base em reflexão comparativa e dedutiva. Por exemplo, em Macária, caso de devotio, ou seja, de sacrifício pela colectividade, considerámos que foi o cutelo sacrificial, a hipótese mais consentânea. Efectivamente, neste motivo, quando não é encontrada nas fontes informação sobre o meio utilizado, assumimos que este é a arma, mais especificamente, o cutelo sacrificial. O número expressivo destes exemplos, como Alceste, Cianipo 1 ou Cíane 2, entre tantos ${ }^{54}$, realça um padrão - devotio e cutelo sacrificial - que nos reporta para práticas sociológicas e culturais muito variadas.

Noutros casos, ativemo-nos a certos detalhes esclarecedores da lenda que lhe dão diferentes contextos e, por conseguinte, a enriquecem muito mais. Por exemplo, enquanto que em Narciso 1, como já referido, classificámos o meio em inedia, a variante de Narciso 2 indicia-nos a arma, uma vez que no local do suicídio o chão está manchado de sangue.

Outra situação desta tipologia, com forte conotação simbólica e teatral, é a espada do amado. Exemplifiquemos: Aminías sucumbe empunhando a espada que Narciso, aquele que ama, lhe havia enviado. Amínias não se limita somente a obedecer à necessitas implícita, ele fá-lo diante da porta do amado. A teatralidade enfatiza o simbolismo do acto e adensa a forte carga dramática. A espada é, aliás, das armas referidas, a mais emblemática, pois sugere uma ligação profunda e íntima com o seu

\footnotetext{
${ }^{52}$ Ver Gráfico V.

${ }^{53}$ Ver tabela I e Gráfico VII.

${ }^{54}$ Os casos de devotio são essencialmente concretizados com cutelo sacrificial. Ver gráfico VIII.
} 
dono, assumindo muitas vezes protagonismo na anagnórise, situação essa tão cara aos tragediógrafos gregos. Por exemplo, Pelopeia reconhece no seu pai, através da espada deste, aquele que a violara, facto que ditará o seu suicídio, com essa mesma espada. Dido 2 também protagoniza uma morte eminentemente cénica, na pira, mas cravando a espada de Eneias em si própria, descrição muito erotizada em Virgílio. ${ }^{55}$

A este propósito, não deixa de ser interessante invocar a morte de Catão de Útica. No final da República, Catão é aliado de Pompeu. Após a morte deste no Egipto, continua a resistência em África. Quando vê que é César o vencedor, mata-se em Útica. Mas o significado deste suicídio pretende ser intelectualmente estóico, Catão mune-se do Fédon. Entende que a sua leitura ajudá-lo-á a decidir: "Ainda não tomei uma decisão sobre o meu destino, mas quando a tomar, serei dono de executar aquilo que resolvi”. Apesar dos esforços dos que gravitam à volta dele nessa noite, filho, amigos, aliados, escravos, quando finalmente consegue a espada que a todo o custo lhe negavam, Catão lança o grito do Ipiranga: "Agora pertenço-me!"56. A espada devolve-lhe a autodeterminação e o domínio sobre a situação.

\footnotetext{
${ }^{55}$ Refere expressivamente Edwards 2007183 que a descrição da morte de Dido em Virgílio tem uma "sinisterly erotic dimension".

${ }^{56}$ Plutarco, Catão O Jovem, 69.6 e 70.2 respectivamente.
} 


\title{
III. Corpus
}

\begin{abstract}
ADRASTO 1 (ver Hipónoo)
Adrasto é rei de Argos. Dez anos após a primeira expedição dos Sete contra Tebas, empreende com os Epígonos (nome dado aos outros seis filhos dos heróis dessa expedição), uma nova guerra contra Tebas, para restabelecer Polinices no trono. Tomam a cidade, aí estabelecendo como rei Tersandro, filho de Polinices. Mas Egialeu, filho de Adrasto, é morto por Laódamas, filho de Etéocles. Adrasto morre de dor pela perda do filho.
\end{abstract}

Motivo: dolor

Modo: ?

Temas: Argos, amor paternal, perda de filho, Sete contra Tebas

Fontes:

BNP s.v. Adrastus 154-155 nº1 (versão 1)

Grimal s.v. Adraste 13 (versões 1 e 2)

RE s.v. Adrastos 411-416 n ${ }^{\circ} 1$ (versão 1: o velho Adrasto morre de desgosto pela perda do filho Egialeu na guerra; Pausânias, 1.43, morreu de velhice e dor pela perda de Egileu)

Pausânias, 1.43.1 (Egialeu morre em combate)

[Van Hoof: não regista]

\section{ADRASTO 2 (ver Adrasto 1)}

A história base é a mesma, relativa à disputa pelo trono de Tebas, mas, na versão de Higino, Adrasto e Hipónoo atiram-se ao fogo por ordem de Apolo.

Motivo: devotio

Modo: imolação pelo fogo

Temas: Apolo, Argos, oráculo

Fontes:

BNP s.v. Adrastus 154-155 nº1 (versão 1; ver também Adrastus nº 2, onde um Adrasto é morto por Diomedes na Ilíada, juntamente com seu irmão)

Grimal s.v. Adraste 13 (refere uma versão da imolação de Adrasto)

Higino, Fábulas, 242

[Van Hoof s.v. Adrastos: devotion, fire, +, Hyg.Fab. 242] 


\section{ADRASTO 3}

De origem frísia, Adrasto, filho de Midas, exilado para se purificar da morte involuntária de um irmão, refugia-se na corte de Creso e torna-se seu amigo. O rei, conhecendo, por um sonho, que seu filho Átis morreria vítima de arma, evita todas as situações e circunstâncias que possam proporcionar tal incidente. Só por insistência do jovem príncipe permite que ele participe na caçada a um perigoso javali. Por precaução, dá-lhe a companhia de Adrasto, como seu guardião. Infelizmente, uma lança atirada por este falha o alvo e atinge o príncipe. Mesmo desculpado pelo rei, Adrasto degola-se sobre o túmulo do príncipe.

Motivo: dolor

Modo: arma

Temas: amizade, engano, hospitalidade

Fontes:

BNP (não consta esta lenda)

Grimal (não refere esta lenda)

RE s.v Adrastos $416 \mathrm{n}^{\circ} 4$ (de origem frísia, mata-se sobre o túmulo de Átis, filho de Creso, que numa caçada matara por engano; aus Kummer 'dor, desgosto)

Heródoto, 1.34-45 (degolou-se sobre o túmulo); 5.7

[Van Hoof s.v. Adrastos: pudor, weapons, +, Her. 1.45]

AGLAURO (ver Cécrops, filhas de)

Atena entra na forja de Hefesto, que a tenta violar. Do esperma derramado sobre a perna de Atena e por esta lançado à terrra, nasce Erictónio, que é confiado à guarda das três filhas de Cécrops - Aglauro, Herse e Pândroso - , com a condição de não destaparem o cesto onde estava a criança. Movidas pela curiosidade, não respeitam a ordem da deusa. Assustadas com o que vêm (duas serpentes de guarda à criança ou uma criança com cauda de serpente) enlouquecem e atiram-se do alto da Acrópole. Aglauro é a única que não espreita. Segundo uma lenda do séc. IV, Aglauro suicida-se para salvar a pátria. É cultuada num santuário na Acrópole, sendo considerada a primeira sacerdotisa de Atenas. Teria dado o nome ao demo Argile.

Motivo: devotio

Modo: precipitação

Temas: Atena, Hefestos, mito etiológico, suicídio colectivo, sexualidade dos deuses, vingança dos deuses

Fontes:

BNP s.v. Aglaurus 344 n² (lenda do séc. IV, Aglauro suicidou-se para salvar a pátria. É cultuada num santuário na Acrópole, sendo considerada a primeira sacerdotisa de Atenas. Teria dado o nome ao demo Argile); s.v. Erichtonius 31 n $^{\circ}$; s.v. Herse 277 (loucas, Herse e Aglaurus atiram-se da Acrópole); s.v. Arrhephoroi 23-24; s.v. Pandrosus 437-438

Grimal s.v. Érictonios 145; s.v. Aglauros $\mathrm{n}^{\circ}$ 2; s.v. Cécrops 82-83; s.v. Hersé 208; s.v. Pandrosos 344 (por vezes adiciona-se uma quarta irmã)

RE s.v. Aglauros $825-830$ n$^{\circ} 2$; s.v. Herse $1146-1149$ n$^{\circ} 1$; s.v. Kekrops $119-125$

Apolodoro 3.14.4 (atiram-se do alto dos rochedos da Acrópole)

Higino, Fábulas, 166 (insânia, afogamento)

Ovídio, Met., 2.551-561 ; 787-832 (por inveja ou ciúme de Herse, Aglauro foi metamorfoseada em estátua de pedra); 3.189; Met. 2.552-565 (Aglauro, a única a mirar, foi metamorfoseada em ave)

Pausânias 1.18.2 (Pândroso não olhou; as outras duas ficaram loucas)

[Van Hoof s.v. Aglauros et Herse, furor, jumping, +, Paus. 1,18,2] 


\section{ÁGRIO}

Filho de Partáon, da Etólia, destrona Eneu. O neto deste, Diomedes, depois da Guerrra de Tróia decide vingar seu avô Eneu. Expulsa Ágrio e restitui o reino. Em consequência, Ágrio mata-se.

Motivo: pudor

Modo: ?

Temas: Guerra de Tróia, perda de poder político, vingança de família

Fontes:

BNP s.v. Agrius 395 nº 1 (versão de Higino)

Grimal s.v. (nada diz)

RE s.v. Agrios 896-897 nº5 (versão de Higino)

Higino, Fábulas, 175, 242.2 (mata-se)

Ov. Ep.9.153 e Pont. 3.9 .9 (não refere suicídio)

[Van Hoof s.v. Agrios: pudor, +, Hyg.Fab. 242,1 (erro)]

\section{ÁJAX 1}

Ájax, rei de Salamina, é filho de Télamon e de Peribeia. Depois de terminada a Guerra de Tróia, Ájax pretende que Helena seja punida com a morte, por adultério. Os Atridas opõem-se, e Ulisses consegue que Helena seja entregue a Menelau. Ájax pede, então, que lhe seja atribuído, como parte do prémio, o Paládio, estátua de Palas Atena com propriedades mágicas. Com nova intervenção de Ulisses, também este pedido sai gorado. Ájax ameaça vingar-se de Menelau e de Agamnénon, que se protegem com uma guarda. No dia seguinte, de manhã, Ájax é encontrado morto, trespassado pela sua espada.

Motivo: pudor

Modo: arma

Temas: adultério de Helena, Guerra de Tróia, Paládio, prémio do saque

Fontes:

BNP s.v. Ajax Telamonius 409-410 n 1

Grimal s.v. Ajax 23 [II]

RE s.v. Aias 930-940 n³ (ofensa; espada)

Homero, Odisseia, 11.541-567 (no além, ainda detesta Ulisses)

[Van Hoof s.v. Aiax: pudor, weapons, +, Hom.Od. 11.541-567]

\section{ÁJAX 2}

Na versão preferida pelos trágicos, depois da Guerra de Tróia, Ájax Telamónio não consegue a distinção de lhe serem entregues as armas de Aquiles, que Atenas destinara ao guerreiro que mais terror tivesse inspirado aos troianos. Num acesso de loucura, ataca os rebanhos dos Gregos pensando que eram os próprios inimigos. Quando recobre consciência, mata-se. A má sina de Ájax está relacionada com ira de Atena perante a hybris do herói (proclama que pode alcançar a vitória mesmo sem a ajuda dos deuses).

Motivo: furor

Modo: arma

Temas: engano, divisão do saque, Guerra de Tróia, hybris

Fontes:

BNP s.v. Ajax Telamonius 409-410 nº 1 
Grimal s.v. Ajax 23 [II]

RE s.v. Aias 930-940 n³ (loucura, espada)

Higino, Fábulas, 107.3 (gladio 'com a espada), 242.1

Ovídio, Met. 13.382-398 (por dolor — despeito, ira, rancor-mata-se com espada

Sófocles, Ájax, 748-777 (hybris), 815-865 (decide matar-se com arma; 835-844, lançando imprecações contra os Atridas; 898-919 Tecmessa comenta o suicídio de Ájax]

[Van Hoof: não regista]

\section{ALCESTE}

Filha de Pélias, irmã de Medeia, de Iolcos, era muito bela e virtuosa. Casou com o rei Admeto, da Tessália, que a conquistou depois de suplantar duras provas impostas por Pélias. Quando o marido está a ponto de morrer, por não ter cumprido todos os rituais de Ártemis, oferece-se para morrer em seu lugar, pois nem pai nem mãe aceitaram substituí-lo (versão de Eurípides, Alceste, 466-468, 634-650).

Héracles desce aos Infernos e trá-la de volta (versão de Eurípides, Alceste, 1006-1163), ou Perséfone fá-la regressar à vida.

Motivo: devotio

Modo: arma

Temas: amor conjugal, catábase, deus ex machina, donzela como prémio, ressurreição, vingança de Ártemis, superioridade do homem

Fontes:

BNP s.v. Alcestis 441

Grimal s.v.: Admète 10; s.v.: Alceste 25

RE s.v. Alkestis 1513-1514; s.v. Admetos 377-380 nº 1

Eurípides, Alceste (v. 37, 434, 524, 682: morrer em vez de Admeto; 74: sacrifício com espada; v.226-230: suicídio em acção extracénica, degolada ou enforcada ; 252-257: Alceste moribunda; 280 ss: dita as últimas vontades; 391 morre, depreende-se que é atingida por arma sacrificial, segue-se definhamento lento até à morte; 1058: pelo seu gesto de Alceste é dita euergetis 'benfeitora'; 1006-1163: Héracles trá-la do Hades)

Higino, Fábulas, 51, 243.4

[Van Hoof s.v. Alkestis: devotio, ?, +, Hyg.Fab. 243,4]

\section{ALCÍMEDE (ver Éson)}

Alcímede é mulher de Éson, fundador de Iolco (noutras versões a mulher chama-se Polimede, Polímele ou Anfínome), mãe de Jasão e filha de Autólico. Mas Pélias, o meio-irmão de Éson, condena-o à morte. Então Alcímede, com o filho distante na perigosa expedição dos Argonautas, e o marido morto, lança uma maldição sobre Pélias e enforca-se.

\section{Motivo: exsecratio}

Modo: forca

Temas: amor conjugal, Argonautas, Iolco

Fontes:

BNP s.v. Alcimede 449-450; (não regista Polymede)

Grimal s. v. Aeson 16; s.v. Pélias 353-354; s.v. Polymédé 385 (também se chama Alcímede)

RE s.v. Alkimede $1540 \mathrm{n}^{\circ} 1$ (remete para Aison e para Iason); s.v. Polymede 1762-1763 (nomes alternativos: Polymea, Polymele, Polypheme, Alkimede, Amphinome)

Apolodoro, Biblioteca, 1.9.16 (Polimede mãe de Jasão); 1.9.27 (Polimede, mãe de Jasão, enforca-se amaldiçoando Pélias) 
Diodoro, 4.50 (Pélias força o pai de Jasão a beber sangue de touro; a mãe de Jasão, Anfínome, lança maldição e mata-se com espada)

Valério Flaco, 1.761-818 (chorando o filho, Alcímede decide morrer com o marido por ingestão de sangue de touro)

[Van Hoof: não regista]

\section{ALCÍNOE 1}

Alcínoe é de Corinto e contrata uma fiandeira mas, quando esta termina o trabalho, não lhe paga o salário. A fiandeira amaldiçoa-a, invocando Atena, patrona das fiandeiras. A deusa enlouquece Alcínoe, que logo se apaixona por um hóspede, Xanto, estrangeiro de Samos. Para o seguir, deixa marido e filhos. Quando toma consciência do acto, já em plena travessia, clama, desesperada, pela família que abandonou e acaba por se atirar ao mar, afogando-se.

Motivo: furor

Modo: afogamento

Temas: adultério com hóspede, engano, hospitalidade, maldição, tecelagem, vingança divina

Fontes:

BNP (não regista)

Grimal s.v. Alcinoé 25

RE (não regista)

[Van Hoof s.v. Alkinoe: mala conscientia, jumping, +, Parthenios, Er.Path. 27,2; cf. p.121: Alcínoe afoga-se por mala conscientia]

\section{ALCÍNOE 2 ver Cleópatra}

[Van Hoof: não regista]

\section{ALCÍONE 1}

Alcíone é filha de Éolo e Enárete (ou de Egíale), casada com o rei Céix de Tráquin. Segundo Ovídio, Céix parte em viagem marítima e naufraga, aparecendo em sonho à sua fidelíssima esposa Alcíone, a noticiar a sua morte. Desesperada, Alcíone logo decide também morrer, indo encontrar na praia o cadáver do marido naufragado. Ambos desaparecem no meio das ondas, como que metamorfoseando-se nas aves homónimas.

Motivo: dolor

Modo: afogamento

Temas: engano, maldição, metamorfose, perda de marido, tecelagem, vingança divina

Fontes:

BNP s.v. Alcyone $461 \mathrm{n}^{\circ} 2$

Grimal s.v. Alcyoné 27; s.v. Céyx 87 n²

RE s.v. Alkyone 1579-1580 nº4; s.v. Alkyonides 1583 a).

Higino, Fábulas, 65 (propter amorem ipsa se in mare praecipitauit 'por amor, ela atirou-se ao mar')

Ovídio, Met. 9.410-750 (a versão artística deixa em suspenso o modo da morte, mas depreendese afogamento)

[Van Hoof: não regista] 


\section{ALCÍONE 2 (ou Endeis)}

Alcíone, ou Endeis, é filha de Esciro e Cariclo e mulher de Éaco. Esciro aparece na lenda de Teseu como um monstro que atormentava os viajantes. Teseu vence-o e lançao ao mar, onde dá o nome a escolhos ou às Rochas Cirónicas, na região de Mégara. Alcíone lança-se ao mar depois da morte do pai. É transformada em alcíone. A zona do afogamento passa a chamar-se Mar de Alcíone.

Motivo: dolor

Moedo: afogamento

Temas: amor filial, metamorfose, mito epónimo, perda de pai, Teseu

Fontes:

BNP s.v. Alcyonides 462 n $^{\circ} 2$ (“Alcyone, the daughter of Sciro"); s.v. Aeacus 164-165 (não refere morte); s.v. Endeis (remete para Aeacus); s.v. Sciron 95-96

Grimal s.v. Sciron 417 (não inclui suicídio da filha); s.v. Charyclo no 2; s.v. Cychrée 107; s.v. Éaque 131 (desposou Endeis, a filha de Círon) ; s.v. Poséidon 389-391 (refere bandido Círon); s.v. Thésée 450-455 (Teseu mata Círon);

RE s.v. Alkyone 1579-1581 nº3; s.v. Alkyonides 1583 d)

Ovídio, Met. 7.443-447

[Van Hoof: não regista]

\section{ALCIÓNIDAS (filhas de Alcioneu)}

Desesperadas, ao verem seu pai morto por Héracles, as sete filhas de Alcioneu atiram-se ao mar e são metamorfoseadas em alcíones.

Motivo: dolor

Modo: afogamento

Temas: amor filial, Héracles, metamorfose, mito epónimo, perda de pai, suicídio colectivo

Fontes:

BNP s.v. Alcyonides $462 \mathrm{n}^{\circ} 2$ (suicídio); (remete para Alcyoneus, onde nada diz)

Grimal s.v. Alcyonée $28 \mathrm{n}^{\circ} 1$ (suicídio)

RE s.v. Alkyonides 1583 b)

[Van Hoof: não regista]

\section{ALTEIA (ver Meleagro)}

Alteia é filha de Téstio, mãe de Meleagro e de Dejanira, mulher de Eneu, rei dos Etólios, de Cálidon. As Moiras anunciam-lhe que o filho Meleagro, nascido há sete dias, morrerá quando o tição que se encontra no átrio se consumir todo. Alteia apaga-o logo e esconde-o num cofre. Meleagro cresce e, durante a caçada de Cálidon, mata um tio, irmão da mãe. Tomada de raiva, Alteia acende o tição e Meleagro morre. Desesperada, Alteia enforca-se.

Segundo Apolodoro, no enterro de Meleagro, as carpideiras são metamorfoseadas em aves.

Motivo: conscientia

Modo: forca

Temas: aves de Meleagro, caçada de Cálidon, carpideiras, destino

Fontes:

BNP s.v. Althaea $550 n^{\circ} 1$ 
Grimal s.v. Althée 30; s.v. Méléagre 284; s.v. Oenée 325-326

RE s.v Althaia 1693-1696 n 2 (dois modos de suicídio)

Apolodoro, Biblioteca, 1.8.3 (forca; aves de Meleagro)

Higino, Fábulas, 171

Ovídio, Ep.9.157 (Dejanira refere-se ao ferro com que sua mãe se suicidou)

[Van Hoof s.v. Althaia: dolor, weapons, +, Ov.Her. 9,157]

\section{ALTÉMENES}

Catreu é filho de Minos e de Pasífae e sucessor ao trono de Creta. Tem três filhas: Aérope, Clímene, Apemósine, e um filho, Altémenes. Um oráculo diz-lhe que um dos seus filhos o matará. Catreu esconde a revelação, mas Altémenes e Apemósine descobrem-na e põem-se em fuga, chegando a Rodes, onde fundam Creténia, designação tirada do nome da sua ilha natal.

Catreu, que não esquece o oráculo, dá as suas duas outras filhas a Náuplio, para que este as venda como escravas no estrangeiro. Quando envelhece, quer deixar o reino ao seu filho Altémenes e vai procurá-lo em Rodes. Desembarca num sítio ermo, onde se depara com uns vaqueiros que pensam que ele e os seus homens são piratas. Tenta identificarse, mas o ladrar dos cães impede o diálogo. Os pastores apedrejam-no. Altémenes surge e mata-o com um dardo. Apercebendo-se do que fez, Altémenes invoca as divindades infernais para que seja engolido pela terra. O pedido é cumprido.

Motivo: dolor

Modo: precipitação

Temas: Creta, divindades infernais, engano, oráculo, pastores, piratas

Fontes:

BNP s.v. Althaemenes 551

Grimal s.v. Catrée 82; s.v. Aéropé 15-16 (nada diz)

RE s.v. Althaimenes $1696 \mathrm{n}^{\circ} 1$

Apolodoro, Biblioteca, 3.2

Didodoro Sículo, 5.59 (fica errante e morre de angústia)

[Van Hoof s.v. Althaimenes: pudor, jumping, +, Apoll. 3,2,2,3]

\section{AMATA}

Quando Eneias chega ao Lácio, pede apoio ao rei Latino, que se dispõe a dar-lhe a sua filha em casamento. A rainha Amata opôe-se e move-lhe guerra, juntamente com Turno, seu prometido genro. Com a derrota deste, desesperada assume a sua culpa e enforca-se.

Motivo: conscientia

Modo: forca

Temas: influência política feminina, Itália, matriarcado, príncipe estrangeiro

Fontes:

BNP s.v. Amata 563

Grimal s.v. Amata 30

BNP s.v. Amata 563

Virgílio, Eneida, 12.595-603 (assume a culpa)

[Van Hoof s.v. Amata: dolor, hanging, +, Verg.Aen. 12,603] 


\section{AMÍNIAS (cf. Narciso 2)}

Na versão beótica da lenda, o jovem Amínias, de Téspias, junto do monte Hélicon, apaixona-se pelo belo Narciso. Mas este é avesso ao amor e não corresponde. Narciso acaba por lhe enviar uma espada. Compreendendo o significado do gesto, Amínias mata-se frente à porta do amado, lançando imprecações sobre ele.

Motivo: exsecratio

Modo: arma

Temas: desamor, espada do amado, Hélicon, homo-erotismo, Narciso

Fontes:

BNP (nada diz)

Grimal s.v. Narcisse 308-309

RE s.v. Ameinias $1818 \mathrm{n}^{\circ} 2$

[Van Hoof s. v. Ameinas: exsecratio, weapons, +, Konon, frg.24 (FGrH I 197)]

\section{ANA (ver Dido 2)}

Numa variação da lenda de Dido, não teria sido esta, mas sua irmã Ana a imolar-se pelo fogo por amor a Eneias, que partira.

Motivo: dolor

Modo: imolação pelo fogo

Temas: Cartago, Eneias, Fenícia, príncipe estrangeiro

Fontes:

BNP s.v. Anna 701 (origem semítica do nome); s.v. Dido 389 (segundo Varrão, é Ana que se imola por Eneias)

Grimal a.v. Anna Perenna 37 (não refere suicídio)

RE s.v. Anna $2223 n^{\circ} 1$

[Van Hoof: não regista]

\section{ANCURO}

Ancuro é filho de Midas e rei da Frígia. Próximo da capital, Górdio, abre-se um abismo enorme que ameaça engolir a cidade. Perante o perigo, Ancuro pede a ajuda do oráculo. Este diz-lhe que Ancuro tem que lançar na voragem aquilo que lhe é mais precioso. Anacuro começa por lançar o ouro e as jóias que possui, mas nada acontece. Compreendendo então o sentido do oráculo, lança-se a si próprio no abismo, que se fecha imediatamente sobre ele.

Motivo: devotio

Modo: precipitação

Temas: anel de Polícrates, Ásia, oráculo, ouro e prata

Fontes:

BNP (não regista)

Grimal s.v. Anchouros 35

RE s.v. Anchuros 2111

[Van Hoof s.v. Anchouros: devotio, jumping, +, Plout.Mor. 306F] 


\section{ANFÍON}

É filho de Zeus e de Antíope, marido de Níobe. Ovídio descreve a hybris de Níobe, filha de Tântalo, a qual se vangloria da sua progénie e felicidade, desprezando o culto de Latona. Esta leva Febo Apolo a matar com suas flechas os sete filhos e depois as sete filhas de Níobe. Perante a carnificina dos filhos, e seguindo a versão de Ovídio, o pai Anfíon mata-se de dor, com arma de ferro.

Motivo: dolor

Modo: ferro

Temas: amor paternal, Apolo, castigo das divindades, felicidade, hybris, Latona, progénie

Fontes:

BNP s.v. Amphion $604 \mathrm{n}^{\circ} 1$

Grimal s.v. Amphion 32 (não refere suicídio, mas loucura e morte por Apolo)

RE s.v. Amphion 1944-1948 nº

Ovídio, Met. 6.146-312 (v. 271-272: arma)

[Van Hoof: não regista]

\section{ÂNIO}

O rei etrusco Ânio tem uma filha, Sália. O jovem Catero apaixona-se por ela, rapta-a e leva-a para Roma. Ânio tenta, em vão, apanhar os fugitivos. Em desespero, atira-se ao rio mais próximo, que passa a ter o seu nome (actualmente o Anieno, que se junta ao Tibre a norte de Roma).

Motivo: pudor

Modo: afogamento

Temas: hidrónimo, mito epónimo, hidrónimo, rapto, Roma

Fontes:

BNP s.v. Anio 699-700 (não menciona morte); s.v. Annius 705-706 (nada diz)

Grimal s.v. Cathètos 81

RE s.v. Annius 2261

Plutarco, Obras Morais, 315e

[Van Hoof s.v. Annius: pudor, jumping, +, Plout.Mor. 315E]

\section{ANTICLEIA}

Anticleia é mãe de Ulisses e mulher de Laertes. Durante a longa ausência de Ulisses, é consumida pelo desgosto, ou, segundo Higino, mata-se perante falsa notícia da sua morte. Ulisses vem a encontrá-la quando desce ao além.

Motivo: dolor

Modo: inedia

Temas: amor maternal, catábase, Guerra de Tróia

Fontes:

BNP s.v. Anticlea 741-

Grimal s.v. Anticlée 38

RE s.v. Antikleia $2425 n^{\circ}$ 4; s.v. Nauplios 2004-2008

Higino, Fábulas, 243 (mata-se perante falsa notícia)

Homero, Odisseia, 11.202 (morre de saudade) e 15.358 (morre de tristeza)

[Van Hoof s.v. Antikleia: dolor, ?, +, Hyg.Fab. 243,1] 


\section{ANTÍGONA 1}

Filha do incesto de Édipo com sua mãe Jocasta. Desafiando a ordem do tio Creonte, Antígona faz os rituais religiosos ao irmão morto, Polinices, espalhando pó sobre o cadáver. Creonte, seu prometido sogro, condena-a então à morte, manda-a encerrar viva numa caverna (ou no túmulo dos Labdácidas), onde ela se enforca.

Motivo: necessitas

Modo: forca

Temas: Tebas, tirania, sepultura, Édipo

Fontes:

BNP s.v. Antigone $745 \mathrm{n}^{\circ} 3$ (situa o suicídio na tragédia)

Grimal s.v. Antigone $38 \mathrm{n}^{\circ}$ 1; s.v. Pélée 352-353

RE s.v. Antigone 2401-2404 no 3

Apolodoro, Biblioteca, 3.7.1 (Antígona roubou o corpo de Polinices, foi encerrada no túmulo)

Higino, Fábulas, 72 (Antígona é morta por Hémon, que se suicida manu aliena, por necessitas), 243.8

Sófocles, Antígona, 1220-1221 (forca)

[Van Hoof s.v. Antigone: desperata salus, hanging, +, Soph.Ant. 1221; cf. p. 91]

\section{ANTÍGONA 2}

Antígona é filha de Eurícion, da Tessália, e mulher de Peleu. Acidentalmente, Peleu mata o sogro na caçada de Cálidon e refugia-se na corte de Acasto, filho de Pélias e rei de Iolco. Acasto purifica-o, mas a sua mulher, Astidameia, apaixona-se por Peleu, que se lhe recusa. Astidameia congemina anunciar então, numa carta enviada a Antígona, que Peleu vai casar com Estérope, a filha de Acasto. Desesperada, Antígona enforca-se.

Motivo: dolor

Modo: forca

Temas: adultério, caçada de Cálidon, desamor, Tessália, vingança feminina

Fontes:

BNP s.v. Antigone $745 \mathrm{n}^{\circ} 2$

Grimal s.v. Pélée 352-353; s.v. Acaste 3; s.v Stérope 429 n 5

Lexikon s.v. Peleus 2242-2243

RE s.v. Antigone 2401-2404 n 2

[Van Hoof: não consta]

\section{ANTílOCO}

É o filho mais velho de Nestor, rei de Pilos, e de Eurídice. Quando vê seu pai ser atacado e em risco de ser morto, corre a interpor-se e perece.

Motivo: devotio

Modo: arma

Temas: amor filial, Guerra de Tróia, provocatio, Nestor, suicídio manu aliena

Fontes:

BNP s.v. Antilochus

Grimal s.v. Antiloque 38-39

RE s.v. Antilochos 2429-2431 n 1

Píndaro, Odes Píticas, 6.28-42 (salva ao pai enfrentando Mnestor)

[Van Hoof s.v. Antilochos: devotio, provocation, +; cf. Pind.Pyth. 6,28] 


\title{
APRÍATE
}

Apríate é de Lesbos e é amada por Trambelo, filho de Télamon. Mas este amor não é correspondido. Trambelo decide então raptá-la, a jovem resiste e atira-se ao mar.

Motivo: desperata salus

Modo: afogamento

Temas: desamor, Lesbos, rapto, viagens marítimas,

Fontes:

BNP (não regista)

Grimal s.v. Apriaté 43

RE s.v. Apriate 269-270

[Van Hoof s.v. Apriate: pudor, jumping, + Parthenios. Er.Path. 26,2]

\section{AQUILES}

É filho de Peleu e Tétis, rei dos Mirmidões, na Ftia. A sua lenda é rica em variantes. Assim, um oráculo prediz a sua morte em Tróia. No entanto, a cidade não poderá ser vencida sem a intervenção de Aquiles. Este oráculo parece explicar algumas peripécias da sua infância e juventude, que indicam que cedo opta por uma vida apagada e longa em detrimento de uma vida curta e gloriosa. Mas, graças aos artifícios de Ulisses, Aquiles é levado a participar na Guerra de Tróia até se retirar do combate depois de nove anos de façanhas. Quando decide regressar à guerra, depois da morte de Pátroclo, o seu cavalo Xanto prediz que a sua morte está próxima. O mesmo lhe anuncia Tétis, ou Heitor, quando Aquiles o mata. Pode assim, entender-se, que a sua morte acaba por ser voluntariamente aceite e procurada, apesar de tentativas alheias, e eventualmente suas, para não entrar em guerra ou para se ausentar do palco dos combates.

Motivo: necessitas

Modo: arma

Temas: amizade, Guerra de Tróia, perda de amigo, suicídio manu aliena, provocatio, vingança de um amigo

Fontes:

BNP s.v. Achilles 89-96

Grimal s.v. Achilles 5-9

Lexikon s.v. Achilleus 10-11 no 1

RE s.v. Achilleus 221-248

[Van Hoof s.v. Achilles: dolor, weapons, -, Hom.Il. 18,34]

\begin{abstract}
ARACNE
É uma rapariga da Lídia, muito reputada na tecelagem, arte que teria aprendido com Atena. Torna-se vaidosa e soberba ao renegar o apoio da deusa. Num concurso entre ambas para se encontrar a melhor, Palas Atena destrói o trabalho de Aracne e esta enforca-se. Mas Atena não a quer morta, metamorfoseando-a em aranha, que em grego se diz arachne.
\end{abstract}

Motivo: pudor

Modo: forca

Temas: hybris, Lídia, metamorfose, mito epónimo, tecelagem, vingança de Atena

Fontes:

BNP s.v Arachne 944 
Grimal s.v. Arachné 43

Lexikon s.v. Arachne $238 \mathrm{n}^{\circ} 1$

RE s.v. Arachne 367-368 nº 1

Ovídio, Met. 6.1-145

[Van Hoof s.v. Arachne: pudor, hanging, +, Ov.Met. 6,134]

\begin{abstract}
ARIADNE
É filha de Minos e Pasífae. A versão do suicídio por enforcamento, depois de abandonada por Teseu, é somente relatada por Plutarco. Este dá conta da existência de versões contraditórias, entre elas a do suicídio.
\end{abstract}

Motivo: dolor

Modo: forca

Temas: desamor, Creta, Teseu

Fontes:

BNP s.v. Ariadne 1076-1077 (não refere suicídio)

Grimal s.v. Ariane 50 (nada diz)

RE s.v. Ariadne 803-811 nº 1 (enforca-se; Plut. Thes. 20.1]

Pausânias, 10.29 .3 (não refere a morte)

Plutarco, Teseu, 20.1

[Van Hoof s.v. Ariadne: dolor, hanging, +, Plout.Thes. 20]

\title{
ÁSPALIS
}

Meliteu, filho de Zeus e da ninfa Ótris, é exposto, à nascença, num bosque. Sobrevive graças a um enxame de abelhas que o alimenta. Quando cresce, vai para a Tessália e aí funda a cidade de Meliteia, de que se torna tirano, usufruindo sexualmente de raparigas. Agrada-se de Áspalis e ordena que lha tragam, mas esta enforca-se antes da chegada dos soldados que a vêm buscar. O irmão da rapariga, Astígites, disfarçado com a roupa de Áspalis, mata o tirano com uma espada e torna-se rei. Entretanto o corpo de sua irmã desaparece, é substituído por uma estátua de madeira e passa a ser objecto de culto.

Motivo: desperata salus

Modo: forca

Temas: engano, exposição de crianças, mito etiológico, tiranicídio, tirano devasso

Fontes:

BNP (não regista)

Grimal s.v. Aspalis 50

RE s.v. Aspalis 1711

[Van Hoof: não regista]

\section{ASSÁON (ver Níobe)}

Níobe é filha de Assáon e mulher do assírio Filoto, que morre durante uma caçada. Assáon quer então unir-se à sua filha. Esta recusa-o. Assáon vinga-se de forma terrífica. Convida os 20 filhos de Níobe, os seus netos, para uma festa e incendeia o palácio. Todos morrem queimados. Com o remorso, Assáon mata-se.

Motivo: conscientia

Modo: ? 
Temas: Assíria, caçada, incesto

Fontes:

BNP s.v. Niobe $770-772$

Grimal s.v. Assaon 55; s.v. Niobé $317 \mathrm{n}^{\circ} 2$

RE s.v. Assaon 1741 (Reue 'arrependimento')

[Van Hoof s.v. Assaon: mala conscientia, ?, +, Parthenios, Er.Path. 33,3]

\section{ASTÉRIA}

Astéria é filha do titã Céu e de Febe, irmã de Leto. Febe e Leto são filhas de Úrano (o Céu) e de Geia, a Terra. Amada por Zeus, metamorfoseia-se em codorniz para escapar à perseguição do deus e atira-se ao mar, onde se transforma em ilha, Ortígia, a Ilha das Cordonizes (ortyx em grego), a futura Delos.

Motivo: desperata salus

Modo: afogamento

Temas: Delos, metamorfose, mito epónimo, Zeus

Fontes:

BNP s.v. Asteria $190 \mathrm{n}^{\circ} 2$

Grimal s.v. Astéria 55

RE Asteria $1781 \mathrm{n}^{\circ} 6$

[Van Hoof: não regista]

\section{ASTÍANAX}

É filho de Heitor e Andrómaca. Após a queda de Tróia, e ainda criança, é levado como refém pelos gregos, que o atiram de uma torre, receosos de uma futura vingança. Séneca transforma-o num jovem herói que aceita voluntariamente o sacrifício, avançando para a morte.

Em grego, o seu nome significa 'Rei da Cidadela', deixando entrever um mito epónimo.

Motivo: necessitas

Modo: precipitação

Temas: criança, mito epónimo, sacrifício voluntário

Fontes:

BNP s.v. Astyanax 212 (não explicita sacrifício voluntário)

Grimal s.v. Astyanax 55

RE s.v. Astyanax $1866 \mathrm{n}^{\circ} 1$

Séneca, Troianas, 1102-1103 (sponte 'de livre vontade')

Ovídio, Met. 13.414-416, Íbis, 494 (é atirado)

[Van Hoof s.v. Astyanax: necessitas, jumping, +, Sen.Troades, 1102]

\section{ÁTIS (cf. Ságaris)}

É filho do mortal Agdístis e de Nana, ninfa do rio Sangário. Abandonado à nascença nos montes, é alimentado por um caprino. Mais tarde, emigra da Frígia para a Lídia e torna-se devoto de Cíbele. Extremamente belo, é vítima de amor hermafrodita por parte de Agadístis, enlouquece, castra-se e morre.

$\mathrm{Na}$ versão de Ovídio, Átis prometera a Cíbele manter-se virgem, mas vem a apaixonarse pela ninfa Ságaris. Cíbele provoca a loucura, a que se segue a castração, o que de certo modo é sugerido por outras castrações simultâneas à de Átis. 
Seria cultuado com a deusa, culto que engloba rituais agrários e de iniciação da adultez, com possível relação etimológica com Adónis. A castração faz parte do culto de Cíbele, o que sugere tratar-se de lenda etiológica.

Motivo: furor

Modo: arma

Temas: autocastração, Cíbele, Frígia, hermafroditismo, ira divina, mito etiológico, theriodes bios, virgindade

Fontes:

BNP s.v. Attis 327-329

Grimal s.v. Attis 60; s.v. Sagaris 413 n²

RE s.v. Attis 2247-2252

Ovídio, Fastos, 4. 223-246 (v. 237: castração com saxum 'sílex')

Pausânias, 7.17.7-12 (existência de várias versões da lenda)

[Van Hoof: não consta]

\section{AURA}

Aura é filha da frígia Peribeia e do titã Lelanto. Caçava com as companheiras de Ártemis e era tão veloz como o vento (o seu nome significa brisa). Dioniso ama-a mas não consegue apanhá-la. Então, pede a Afrodite que a enlouqueça e Aura acaba por se entregar. Terão dois gémeos. Mas Aura, tresloucada, despedaça-os e atira-se ao rio Sangário. Zeus transforma-a em nascente.

Motivo: furor

Modo: afogamento

Temas: Dioniso, metamorfose, mito etiológico

Fontes:

BNP (não regista)

Grimal s.v. Aura 61-62

RE s.v. Aura 2424

[Van Hoof: não consta]

\section{BÍBLIS 1}

Filha de Mileto e neta ou bisneta de Minos, apaixona-se pelo irmão-gémeo Cauno. Mas este foge para a Ásia, onde funda a cidade epónima, na Cária. Bíblis enlouquece e anda errante por toda a Ásia até se enforcar ou precipitar-se de um rochedo e ser transformada em hamadríade. Compadecidas com a sua dor, as Ninfas metamorfoseiamna em fonte de lágrimas. Será epónimo da cidade homónima da Fenícia.

Motivo: furor

Modo: precipitação

Temas: Ásia, Creta, diáspora minóica, errância, incesto, metamorfose, mito epónimo

Fontes:

BNP s.v. Byblis 841-842

Grimal s.v. Byblis 69 (precipitação, metamorfose em fonte); s.v. Caunos 82

RE s.v. Byblis $1098-1099$ n $^{\circ} 1$ e 4

Higino, Fábulas, 243.6 (matou-se por amor a Cauno)

Ovídio, Arte de Amar, 1.283-284 (enforca-se); Met. 9.450-465-665; 664 (converte-se numa fonte); Íbis, 365-366 (paixão pelo irmão)

Pausânias, 7.5.10 e 24.5 (fonte Bíblis, cantada por poetas) 
Teócrito, 7.115 (fonte Bíblis)

[Van Hoof s.v. Byblis: dolor, hanging; +, Ov.Ars am. 1,283; cf. p.101: como pode uma ninfa morrer?]

\section{BÍBLIS 2 (ver Bíblis 1)}

A história de Bíblis (ver Bíblis 1) tem uma versão inversa. É o irmão Cauno que a persegue, ela foge e enforca-se. Dá nome a duas cidades, uma na Caria e outra na Fenícia.

Motivo: desperata salus

Modo: forca

Temas: Ásia, assédio de meio-irmão, incesto, mito epónimo

Fontes:

BNP s.v. Byblis 841-842; s.v. Caunus 39-41 n 1 ("their incestuous relationship"; Parthenius 11) Byblis

Grimal s.v. Byblis 69 (enforca-se); s.v. Caunos 82

Higino, Fábulas, 243

[Van Hoof: não regista esta entrada]

\section{BOLINA}

Bolina, assediada por Apolo, atira-se ao mar. É tornada imortal.

Motivo: desperata salus

Modo: afogamento

Temas: assédio sexual, Apolo, sexualidade dos deuses

Fontes:

BNP (não regista)

Grimal (não regista)

RE s.v. $674 \mathrm{n}^{\circ} 2$

Pausânias, 7.23.4

[Van Hoof: não regista esta entrada]

\section{BRISEU}

Briseu é um sacerdote de Apolo, rei de Pédaso e pai de Briseide. Durante o saque de Tróia, Aquiles destrói-lhe a casa e ele enforca-se.

Motivo: pudor

Modo: forca

Temas: Ásia, Guerra de Tróia, saque

Fontes:

BNP s.v. Briseus, Brise 774 (remete para Briseis, que não refere morte de Briseu)

Grimal s.v. Brisès 68

RE s.v. Briseus $857-858 \mathrm{n}^{\circ} 1$

[Van Hoof: não regista]

BRITE (ver Britomártis)

Idêntica à lenda de Britomártis. Brite é filha de Marte (Ares), e por essa razão também chamada Britomártis, seguidora de Ártemis, em Creta. Minos apaixona-se por ela e 
Brite atira-se à água. O seu corpo é encontrado na rede de um pescador. Uma peste assola Creta e o oráculo declara que para pará-la os habitantes locais terão que lhe prestar homenagem como Diana Dictina, a Artémis da rede (diktya em grego).

Motivo: desperata salus

Modo: afogamento

Temas: Ártemis, assédio sexual, Creta, Minos, mito etiológico, pesca

Fontes:

BNP (não regista)

Grimal s.v. Bryté 68

RE s.v. Britomartis 880-881; s.v. Bryte 929

[Van Hoof: não regista]

\section{BRITOMÁRTIS (cf. Dicte)}

É uma cretense, filha de Zeus e de Carme. Na versão de Calímaco, é uma ninfa virgem, companheira de Ártemis em Gortina. O seu nome significa "a Virgem Doce". Minos apaixona-se por ela e persegue-a por toda a ilha de Creta. Apercebendo-se, um dia, que ia ser apanhada, Britomártis salta do alto de uma falésia para o mar. É salva pelas redes dos pescadores, o que explica o epíteto Dictina, 'filha da rede'.

Uma versão de natureza etiológica atribui-lhe a invenção das redes de caça e pesca.

Motivo: desperata salus

Modo: afogamento

Temas: Ártemis, assédio sexual, Creta, Minos, mito epónimo, mito etiológico, suicídio frustrado, virgindade

Fontes:

BNP (não regista)

Grimal s.v. Britomartis 68; s.v. Minos 297-299

Lexikon's a.v. Britomartis $504 \mathrm{n}^{\circ} 2$

RE s.v. Britomartis 880-881; s.v. Diktynna 584-59 (relata a lenda de forma clara)

[Van Hoof s.v. Britomartis-Diktynna: pudor, jumping, +, Kallim.Hymn. In Artem. 195; cf. p.97]

\section{BRÓTEAS 1}

É filho de Tântalo, rei da Frígia ou Lídia, e de Eurianassa, irmão de Pélops e de Níobe. Uma versão da sua vida diz que é um caçador que incorreu na ira de Ártemis. Acreditando ser imune, atira-se ao fogo.

Motivo: furor

Modo: imolação pelo fogo

Temas: Ártemis, Ásia, caça

Fontes:

BNP s.v Broteas $790 n^{\circ} 1$

Grimal (não regista)

RE s.v. Broteas $897-898 n^{\circ} 1$

[Van Hoof: não regista] 


\section{BRÓTEAS 2}

Filho de Tântalo, de Zeus ou de Hefesto, é cego por Zeus por não ter préstimo. Imola-se pelo fogo devido à sua fealdade e por tédio de vida.

Motivo: taedium vitae

Modo: imolação pelo fogo

Temas: Ásia, cegueira, fealdade masculina, vingança de Zeus

Fontes:

BNP s.v Broteas $790 \mathrm{n}^{\circ} 1$ (Lebensüberdruss 'tédio de vida')

Grimal (não regista)

RE s.v. Broteas $897-898 \mathrm{n}^{\circ} 2$

Ovídio, Íbis, 515-517 (cupidine mortis 'por desejo de morrer')

[Van Hoof: não regista]

\section{BUTES}

Butes é filho de Bóreas e meio irmão de Licurgo. São filhos de mães distintas mas nenhuma delas é a mulher legítima do deus, que é Oritia. Butes quer matar Licurgo mas falha os seus intentos e foge com os seus apoiantes para Naxo, onde sobrevive graças à pirataria e ao latrocínio. Chega a atacar a Ftiótide na Tessália para raptar mulheres, mas depara-se com as adoradoras de Dioniso. A maior parte consegue fugir mas a ama do deus, Corónis, é raptada e entregue a Butes. A pedido de Corónis, Dioniso enlouquece Butes, que se mata atirando-se a um poço.

Motivo: furor

Modo: afogamento

Temas: Dioniso, pirataria, Tessália, vingança divina

Fontes:

BNP s.v. Butes 837-838 (é o terceiro dos referidos)

Grimal s.v. Boutès 67; s.v. Coronis $100 \mathrm{n}^{\circ} 3$

Diododro Sículo, 5.50

RE s.v Butes 1080-1081 no 5; s.v. Koronis 1431-1434.

[Van Hoof s.v. Bytes: furor, jumping, +, Diod. 5,50,5]

\section{CÁLAMO}

Cálamo é filho do deus-rio Menandro, situado na Frígia, e o seu nome significa "cana". Mantém uma relação amorosa com um jovem muito belo, Carpo, filho de Zéfiro e de uma das Horas. Um dia, quando ambos se banham no Menandro, Cálamo desafia Carpo para uma corrida de natação, onde este morre afogado. Devastado pela dor, Cálamo pede a Zeus uma morte prematura e deixa-se definhar até se tornar numa cana ou cálamo, na borda do rio.

Carpo significa "fruto"e torna-se o "fruto dos campos", que morre e renasce cada ano.

Motivo: conscientia

Modo: inedia

Temas: amizade, caça, homo-erotismo, Frígia, mito epónimo, perda de amigo

Fontes:

BNP s.v. Calamos $930 \mathrm{n}^{\circ} 1$

Grimal s.v. Calamos 74 (versão utilizada) 
RE s.v. Kalamos $1538 \mathrm{n}^{\circ} 1$ (Carpo foge de seu pai, pede a Zeus uma morte para si e para o seu amigo)

[Van Hoof: não regista]

\section{CALCAS}

Calcas é o adivinho de Micenas ou de Mégara, filho de Testor e, através deste, descende de Apolo, que lhe confere o dom da profecia. Participa na Guerra de Tróia e é ele que sugere a construção do cavalo de Tróia.

Quando a guerra termina, não parte com os gregos, pois sabe que a cólera de Atena vai abater-se sobre estes, devido às injustiças cometidas para com o seu protegido Ájax. Embarca juntamente com Anfíloco, adivinho e filho de Anfiarau, e com os heróis Leonteu, Podalírio e Polipetes. Chegam a Cólofon, onde Calcas encontra Mopso, o adivinho do oráculo de Apolo de Claro. Entram os dois em competição e Mopso ganha. Ora, um oráculo havia anunciado a Calcas que morreria no dia em que encontrasse um adivinho mais hábil do que ele. Morre de desgosto ou mata-se.

Motivo: pudor

Modo: inedia

Temas: adivinhação, Guerra de Tróia, Ásia (Jónia), Mégara, Micenas, oráculo

Fontes:

BNP s.v. Calchas 934-935

Grimal s.v. Calchas 74; s.v. Mopsos $302 \mathrm{n}^{\circ} 2$

RE s.v. Kalchas 1552-1555 (1554: "stribt darauf aus Kummer")

Estrabão, 14.1.27 (lype 'desgosto')

[Van Hoof s.v. Kalchas: pudor, ?, +, Strabo 14,1,27]

\section{CALIPSO}

É filha de Atlas, juntamente com as Oceânides e as Nereides. Teria origem oriental e seria deusa da noite e do reino dos mortos.

Segundo Ovídio, é vítima de amor infeliz por Ulisses. Em Higino, suicida-se.

Motivo: dolor

Modo: ?

Temas: Ásia, desamor, Ulisses

Fontes:

BNP s.v. Calypso 1011 (suicídio)

Grimal s.v. Calypso 77 (não refere suicídio)

RE s.v. Kalypso $1772-1799 \mathrm{n}^{\circ} 1$

OLD s.v. Calypso (versão de Higino)

Ovídio, Ars, 2.119 ss. (paixão por Ulisses)

Higino, Fábulas, 243.7 (versão do suicídio)

[Van Hoof s.v. Kalypso: dolor, ?, +, Hyg.Fab. 243,7]

\section{CALLÍRROE 1}

Terminada a Guerra de Tróia, uma tempestade leva o etólio Diomedes até à Líbia, reino de Lico, o filho de Ares. Lico tem o hábito de sacrificar os estrangeiros ao seu pai. Diomedes é então feito prisioneiro mas a filha de Lico, Calírroe, cujo nome significa 
'Belo Riacho', apaixona-se por ele e liberta-o. Diomedes foge. Desesperada, a rapariga enforca-se.

Motivo: dolor

Modo: forca

Temas: África, desamor, Etólia, Guerra de Tróia, sexualidade feminina, xenofobia

Fontes:

BNP (não regista)

Grimal s.v. Callirhoé $76 \mathrm{n}^{\circ} 4$; s.v. Lycos $267-268 \mathrm{n}^{\circ} 8$

RE s.v. Kallirrhoë $1668 n^{\circ} 1$ (filha de Oceano, ninfa de Perséfone; não refere suicídio)

[Van Hoof s.v. Kallirrhoe Lyci filia: dolor, hanging, +, Plout.Mor. 311C]

\section{CALLÍRROE 2}

Calírroe, uma jovem de Cálidon, nega-se ao amor de Coresso, sacerdote de Dioniso. Coresso queixa-se a Dioniso e o deus espalha uma epidemia de loucura por toda a região. Os habitantes recorrem então ao oráculo de Dodona e ele desvenda que, para acalmar o deus, terão que sacrificar Calírroe ou alguém jovem que tome o seu lugar. Mas quando Coresso vai sacrificá-la, falta-lhe a coragem e degola-se a si próprio no altar. Nesse momento, Calírroe também se degola junto de uma fonte que toma o seu nome.

Motivo: conscientia

Modo: arma

Temas: desamor, Dioniso, mito epónimo, hidrónimo

Fontes:

BNP s.v.Callirhoe 986-987 nº (degola-se)

Grimal s.v. Callirhoé 76, no5

RE s.v. Kallirrhoë 1668-1673 nº7

Pausânias, 7.21.1-5

[Van Hoof s.v. Kallirrhoe Calydonia: pudor, weapons, +, Paus. 7,21,1]

\section{CAMBLES}

Cambles era rei da Lídia. O apetite insaciável que possuía leva-o, uma noite, a devorar a sua própria mulher. Acorda de manhã com um resto da mão na boca. Percebendo o que tinha feito, mata-se. Teria sido o mago Iárdano, arqui-inimigo de Cambles, a provocar esta fome mortífera.

Motivo: furor

Modo: arma

Temas: antropofagia, canibalismo, magia

Fontes:

BNP s.v. Cambles 1015

Grimal s.v. Camblès 77; s.v. Iardanos 223

RE s.v. Kambles 1808

Ateneu, $10.415 \mathrm{~cd}$

[Van Hoof s.v. Kambles: pudor, weapons, +, Athen. 10,415c] 
CÂNACE (ver Macareu)

Cânace é filha de Éolo e de Enárete, da Tessália. Segundo Ovídio (seguindo sem dúvida Eurípides), Cânace tem um filho do seu irmão Macareu. O bebé é escondido entre objectos sagrados e a ama tenta levá-lo para fora do palácio para o expor. Mas um grito do bebé revela-o a Éolo, que o atira aos cães e envia uma espada à sua filha, ordenandolhe que se mate. Descoberta a sua paixão pela irmã, Macareu também se mata.

As tradições mais antigas sobre um Éolo homónimo referem a existência de casamentos entre irmãos na família.

Motivo: necessitas

Modo: espada

Temas: casamento entre irmãos, espada, exposição de crianças, incesto

Fontes:

BNP s.v. Canace 1032 [2]

Grimal s.v. Cânacé 78 ; s.v Macarée $272 \mathrm{n}^{\circ} 1$

RE s.v. Kanake $1853 \mathrm{n}^{\circ} 1$

Ovídio, Ep.11, tem como fonte principal o Éolo de Eurípides; no v.95 refere a arma como ensis. [Van Hoof s.v. Kanake: pudor, weapons, +, Eur.Aiolos]

\section{CANENS}

É uma ninfa do Lácio, casada com o rei Pico, numa relação de amor. Mas, numa caçada, Circe vê Pico e apaixona-se por ele. Transforma-se em javali, leva Pico a persegui-la, afastando-o da mulher. Então Circe declara-se e é rejeitada. Irada, Circe transforma-o em pica-pau. Ao seu desaparecimento, a mulher de Pico não tem sossego, anda errante durante seis dias e seis noites até cair exausta nas margens do Tibre. Com uma última canção (Canens significa 'Cantante'), desaparece. O local passa a chamar-se Canens.

Motivo: dolor

Modo: inedia

Temas: caça, Circe, dolo, fidelidade masculina, Itália, Lácio, mito epónimo, corónimo, sexualidade feminina

Fontes:

BNP (não regista entrada)

Grimal s.v. Canens 78

RE s.v. Canens 1474

Ovídio, Met. 14.320-440 (424: privada de sono e de alimento)

[Van Hoof: não regista]

\section{CÁON}

Cáon, irmão ou companheiro de Heleno, é o herói epónimo da Caónia, uma região do Epiro. Durante uma epidemia,Cáon sacrifica-se pelos seus compatriotas, oferecendo-se como vítima voluntária aos deuses.

Motivo: devotio

Modo: arma

Temas: Epiro, mito epónimo, epidemia

Fontes:

BNP (não regista)

Grimal s.v. Chaon 88 
RE s.v. Chaon $2111 \mathrm{n}^{\circ} 2$

[Van Hoof: não regista]

\section{CÁRILA}

Cárila é órfã e vive em Delfos. Durante uma seca, vai pedir trigo ao rei. Mas este, que só aos ricos fazia benesses, reage batendo com uma sandália no rosto de Cárila. Desesperada e envergonhada, a órfã enforca-se. Com a continuação da carestia, um oráculo responde que se torna necessário expiar a morte da jovem. Em sua honra, passa a celebrar-se em Delfos, de oito em oito anos, um ritual onde, depois de fazer distribuições de provisões, o rei toca com a sandália numa boneca homónima, que depois é enterrada no local onde Cárila se enforcara.

Em congruência, o nome significa a ideia de gratuidade, benemerência para com o povo.

Motivo: pudor

Modo: forca

Temas: Delfos, distribuições de trigo, folclore, mito etiológico

Fontes:

BNP (não regista)

Grimal s.v. Charila $88-89$

RE s.v. Charila 2141 (Volksfreude 'Alegria popular')

Plutarco, Obras Morais, 293d

[Van Hoof s.v. Charilla: pudor, hanging, +, Plout.Mor. 293D; cf. p.116]

\section{CASTÁLIA}

Castália é uma jovem de Delfos. Perseguida pelo deus Apolo nas proximidades do santuário, atira-se a uma fonte, que desde então toma o seu nome e é consagrada a Apolo.

Motivo: desperata salus

Modo: afogamento

Temas: Apolo, assédio sexual, Delfos, fonte, mito epónimo, hidrónimo

Fontes:

BNP s.v. Castalia 1176 (nada refere)

Grimal s.v. Castalie 81

RE s.v. Kastalia $2336-2338 \mathrm{n}^{\circ} 2$

[Van Hoof: não consta]

CÉCROPS, FILHAS de (ver Aglauro, Herse e Pândroso).

Atena entra na forja de Hefesto, que a tenta violar. Do esperma derramado sobre a perna de Atena e por esta lançado à terra, nasce Erictónio, que é confiado à guarda das três filhas de Cécrops - Aglauro, Herse e Pândroso - com a condição de não destaparem o cesto onde está o bebé. Movidas pela curiosidade, não respeitam a ordem da deusa. Assustadas com o que vêem (duas serpentes de guarda à criança ou uma criança com cauda de serpente), enlouquecem e atiram-se do alto da Acrópole.

Este acto está provavelmente relacionado com o ritual das Arréforas, onde objectos sagrados eram transportados por donzelas. As mulheres juravam por Pândroso, a única que obedeceu à deusa. O nome Erictónio foi relacionado com eris 'luta' ou com erion, o 
pano de lã com que Atena limpou o esperma, e com chthon, a terra para onde atirou o pano.

Motivo: furor

Modo: precipitação

Temas: Atena, Hefestos, mito etiológico, sexualidade dos deuses, suicídio colectivo, vingança divina

Fontes:

BNP s.v. Erichtonius 31 n$^{\circ} 1$; s.v. Herse 277 (loucas, Herse e Aglaurus atiram-se da Acrópole); s.v. Arrhephoroi 23-24; s.v. Pandrosus 437-438

Grimal s.v. Érictonios 145; s.v. Aglauros $\mathrm{n}^{\circ} 2$; s.v. Cécrops 82-83; s.v. Hersé 208; s.v. Pandrosos 344 (por vezes adiciona-se uma quarta irmã)

RE s.v. Aglauros 825-830 nº 2; s.v. Herse 1146-1149 nº 1 ; s.v. Kekrops 119-125

Apolodoro 3.14.4 (atiram-se do alto dos rochedos da Acrópole)

Higino, Fábulas, 166 (insania, afogamento)

Ovídio, Met., 2.551-561, 710-835

Pausânias 1.18.2 (Pândroso não olhou; as outras duas ficaram loucas)

[Van Hoof s.v. Aglauros et Herse, furor, jumping, +, Paus. 1,18,2]

\section{CENEU}

É uma jovem de nome Cénis. Ao ser violada por Posídon, pede para ser metamorfoseada em homem invulnerável. De seguida, exige um culto divino. Zeus pune-o lançando os Centauros contra ele. Higino elenca-o nos suicidas.

Motivo: desperata salus

Modo: ?

Temas: assédio sexual, hybris, metamorfose, transsexualidade, vingança de Zeus

Fontes:

BNP s.v. Caeneus 896

Grimal s. v. Caenée 74 (não refere suicídio)

RE s.v. Kaineus 1504-1505

Higino, Fábulas, 14, 242.3 (elenco dos suicidas)

Ovídio, Met.12. 459-532 (só refere a mudança de sexo, para homem)

[Van Hoof s.v. Kaeneus: ?, ?, +, Hyg.Fab. 242]

\section{CÍANE 1}

A ninfa Cíane, quando vê Perséfone (Prosérpina) a ser levada, raptada, por Hades, tenta impedir a passagem nos seus reinos marinhos. Mas Hades fende as águas com o seu ceptro, abrindo uma passagem para o seu reino do além, frustrando a tentativa de obstaculizar o rapto. Despeitada, ferida e triste pela impotência no seu reino, situado entre Cíane e Aretusa, deixa-se definhar até se metamorfosear em várias nascentes, como as actuais Ciani e Pisma, na zona de Nápoles.

No local haveria antigo ritual de atirar animais à água.

Motivo: pudor

Modo: inedia

Temas: mito epónimo, etiológico, hidrónimo, Itália, rapto como ritual de casamento, metamorfose

Fontes:

BNP s.v. Cyane 1032 
Grimal s.v. Cyané 106 n²

RE s.v. Kyane 2234-2235 no 1 e 2

Ovídio, Met. 5.409-437

[Van Hoof: não regista]

CÍANE 2 (ver Cianipo 1)

Lenda de Siracusa. Cianipo é pai de Cíane. Certa noite, embriagado, viola a filha pensando talvez não ser reconhecido; mas Cíane rouba-lhe um anel e vem a identificálo. Entretanto, uma peste cai sobre a cidade. Consultado o oráculo, este anuncia que o flagelo só parará quando a jovem for sacrificada. Cíane mata seu pai e depois suicida-se. Noutra versão, ambos se suicidam para afastar a peste.

Motivo: devotio

Modo: arma

Temas: anagnórise com anel, incesto, oráculo, peste, Siracusa, vinho

Fontes:

BNP (não consta)

Grimal s.v. Cyané 106-107 no 3 (Cíane e seu pai matam-se); s.v. Cyanippos 107 no 3

RE s.v. Kyane 2234-2235 no 3; s.v. Kyanippos 2236-2238 nº 3

Plutarco, Obras Morais, $310 \mathrm{bc}$ (degola o pai e depois suicida-se)

[Van Hoof s.v. Kyane: pudor, weapons, +, Plout.Mor. 310c]

CIANIPO 1 (ver Cíane 2)

Lenda de Siracusa. Cianipo é pai de Cíane. Certa noite, embriagado, viola a filha pensando talvez não ser reconhecido; mas Cíane rouba-lhe o anel e vem a identificá-lo. Entretanto, uma peste cai sobre a cidade. Consultado o oráculo, este anuncia que o flagelo só parará quando for sacrificada uma vida humana que tenha cometido incesto. Cíane e seu pai matam-se.

Motivo: devotio

Modo: arma

Temas: anagnórise com anel, incesto, oráculo, peste, Siracusa

Fontes:

BNP (não consta)

Grimal s.v. Cyané 106-107 no 3 (Cíane e seu pai matam-se)

RE s.v. Kyane 2234-2235 no 3; s.v. Kyanippos 2236-2238 no 3

Plutarco, Obras Morais, 310bc (mata-se sobre o corpo do pai)

[Van Hoof: não regista]

\section{CIANIPO 2}

Cianipo, da Tessália, recusa sacrificar a Dioniso. Casa com a bela e nobre Leucónoe, por quem está apaixonado, mas continua a dedicar-se de forma absoluta à caça. Preenche com ela os seus dias, as noites são de sono reparador. Leucónoe sente-se preterida. Um dia resolve segui-lo secretamente para tentar perceber o que tanto o atrai nos bosques. Mas os cães de caça descobrem-na e despedaçam-na. Quando se apercebe, Cianipo fica desesperado. Levanta uma pira, ai deposita a sua mulher, mata os cães, atira-os também para a pira e em seguida mata-se sobre ela.

O seu nome mistura os significados de cão (kyon) e de cavalo (hippos). 
Motivo: dolor

Modo: imolação pelo fogo

Temas: amor conjugal, caça, Dioniso, perda de mulher, Tessália, theriodes bios

Fontes:

BNP s.v. Cyanippus 1033 no 2 ("dies by his own hand")

Grimal: Cyanippos $107 \mathrm{n}^{\circ} 2$

RE s.v. Kyanippos 2236-2238 n²

Plutarco, Obras Morais, 310e

[Van Hoof s.v. Kyanippos: desperata salus, ?, +, Parthenios, Er.Path. 10,4]

\section{CICNO 1}

Cicno vive nos bosques de Cálidon, na Etólia e é filho de Apolo e de Tíria. A sua beleza não se coaduna com o seu carácter egoísta e maldoso, e com isto afasta amizades e pretendentes. Resta apenas Fílio, que lhe é dedicado. Mas Cicno impõe-lhe uma série de tarefas, que Fílio desempenha com a ajuda de Héracles. Quando saturado, Fílio acaba por também partir. Sentindo-se abandonado, Cicno atira-se com a sua mãe a um lago. Apolo tem pena deles e transforma-os em cisnes. Cicno, em grego, significa cisne.

Motivo: pudor

Modo: afogamento

Temas: caça, Cálidon, castigo da beleza, Etólia, homo-erotismo, metamorfose, suicídio colectivo

Fontes:

BNP s.v. Cycnus 1043-1044 (não refere este Cicno); (não tem entrada Phylios)

Grimal s.v. Cycnos $108-110$ n $^{\circ}$ 5; s.v. Phylios 375

Higino, Fábulas, 154.5

Ov. Met.7.371-381 (só Cicno se atira, não a mãe; esta chama-se Híria)

RE s.v. Kyknos $2435-2451$ n $^{\circ} 5$

[Van Hoof: não regista)

\section{CICNO 1, MÃE de}

Abandonado pelo amado, Cicno afoga-se num lago. A mãe acompanha-o na morte.

Motivo: dolor

Modo: afogamento

Temas: amor maternal, Etólia, perda de um filho, suicídio solidário

Fontes:

BNP (não refere)

Grimal s.v. Cycnos $108-110$ n $^{\circ}$ 5; s.v. Phylios 375

RE s.v. Kyknos $2435-2451$ n $^{\circ} 7$

[Van Hoof: não regista)

\section{CICNO 2}

É filho de Esténelo, rei da Ligúria. Ao chorar a perda do amigo Faetonte (cf. Helíades), Zeus transforma-o em cisne. Em Ovídio, escolhe viver em lagos e pauis, como as Helíades, por ódio ao fogo.

Motivo: dolor 
Modo: inedia

Temas: homo-erotismo, Ligúria, Itália, perda de amado, metamorfose

Fontes:

BNP s.v. Cycnus 1043 n³ (várias fontes); s.v. Phaëton 905 n³

Ovídio, Met. 2.367-400

RE s.v. Kyknos 2435-2451 nº4; s.v. Phaethon 1508-1515 (explicita a versão)

[Van Hoof: não regista)

\section{CIDIPE}

É uma sacerdotiza argiva que pergunta a Hera o que é melhor para os seus dois filhos. De imediato Hera fá-los adormecer no próprio templo e nunca regressam à vida.

Higino afirma que, tendo diligentemente procurado saber o que é melhor para os mortais, se suicida.

Motivo: iactatio

Modo: ?

Temas: felicidade, filosofia, Hera, mito etiológico

Fontes:

BNP s.v. Cydippe 1045 n² (Bíton e Cléobis); s.v. Cleobis and Biton 428 (não refere suicídio)

RE s.v. Biton 544-546 no 1

Grimal (não regista)

DC 64.6

Heródoto, 1.31 (conta a história a Creso)

Higino, Fábulas, 254.5-6 (modelos de pietas)

Plutarco, Obras Morais, 108e (não refere suicídio)

[Van Hoof: não regista)

\section{CILA (ver Niso 1)}

É filha de Niso, rei de Mégara. Por instigação de Vénus, apaixona-se por Minos quando este cerca Mégara. Cila atraiçoa então seu pai, cortando-lhe o cabelo que lhe garantia longo reinado. Mas, em vez de se casar com ela, conforme prometido, Minos ata-a ao navio e Cila morre afogada. Apiedados, os deuses tê-la-iam transformado em ave (Grimal).

Higino diz que, após a recusa de Minos, ela se atira ao mar para evitar o castigo de Niso. Depois da morte, Niso é metamorfoseado em águia marinha, sempre em perseguição de Cila, transformada em peixe (ciris).

Por vezes é confundida com a homónima do mito de Cila e Caríbdis.

Motivo: desperata salus

Modo: afogamento

Temas: Creta, Mégara, mito etiológico, mito epónimo, príncipe estrangeiro, traição

Fontes:

BNP s.v. Skylla $146 \mathrm{n}^{\circ} 2$ (não explicita suicídio); s.v. Nisus $779 \mathrm{n}^{\circ} 1$ (metamorfoseada na ave homónima)

Grimal Scylla $417 \mathrm{n}^{\circ} 2$

RE s.v. Skylla 647-659 n⿳0 2; s.v. Nisos 759-760 n ${ }^{\circ} 1$

Apolodoro, Biblioteca, 3.15.8 (Minos lança-a à água)

Higino, Fábulas, 198 (transformada em peixe)

Ovídio, Met. 8.6-151 (v.145-151: atira-se da popa para fugir ao pai); Tristes, 2.393 ss.

Pausânias, 1.19.4-5 (não refere o suicídio); 2.34.7 (Minos manda matar pela traição) 
[Van Hoof s.v. Skylla: dolor, jumping, +, Hyg.Fab. 197,3 (referência errada; na p.73 também erra ao afirmar: "sacrificed her purple hair")]

CÍNIRAS 1 (ver Esmirna / Mirra)

Primeiro rei de Chipre, para onde emigra vindo da Síria. A razão da vinda poderá ser o incesto involuntário cometido com a filha Esmirna, gerando Adónis (ver Mirra). Em Rodes casa com a princesa local. Suicida-se em consequência do incesto com a filha Esmirna.

Motivo: pudor

Modo: ?

Temas: Apolo, Ásia, Chipre, colonização, incesto

Fontes:

BNP s.v. Cinyras 346-347

Grimal s.v. Cinyras 93 (não refere suicídio)

RE s.v. Kinyras 484-486

Higino, Fábulas, 242.4 (suicida-se em consequência do incesto)

Ovídio, Met. 10.298-502 (não refere suicídio de Cíniras; cf. Mirra)

[Van Hoof s.v. Kinyras: pudor, +, Hyg.Fab. 242,4; cf.p.118]

\section{CÍNIRAS 2}

Tendo perdido uma competição musical com Apolo, de quem seria sacerdote, Cíniras suicida-se, no que é seguido pelas suas cinquentas filhas.

Motivo: pudor

Modo: ?

Temas: Apolo, Ásia, Chipre, competição com deus, música

Fontes:

BNP s.v. Alcyonides 462 n²; s.v. Cinyras 346-347

RE s.v. Kinyras 484-486 (esp. p.485); RE s.v. Alkyonides 1583 c)

Grimal s.v. Alcyonée $28 \mathrm{n}^{\circ} 1$ (refere-se às filhas de Alcioneu)

[Van Hoof: não regista]

CÍNIRAS 2, FILHAS de (ver Cíniras 2)

Após a morte do seu pai em confronto com Apolo, as cinquenta filhas de Cíniras e de Cencreis atiram-se ao mar.

Motivo: dolor

Modo: afogamento

Temas: Apolo, Ásia, Chipre, competição, música, suicídio colectivo

Fontes:

BNP s.v. Alcyonides 462 no2; s.v. Cinyras 346-347

RE s.v. Kinyras 484-486 (esp. p.485); RE s.v. Alkyonides 1583 c)

Grimal s.v. Alcyonée $28 \mathrm{n}^{\circ} 1$ (refere-se às filhas de Alcioneu)

[Van Hoof: não regista] 


\section{CÍQUIRO}

Antipe, uma nobre donzela da Caónia, apaixona-se por um jovem e esse amor é correspondido. Encontram-se os dois, às escondidas dos pais, num bosque sagrado. Um dia, Cíquiro, filho do rei da Caónia, persegue uma pantera nesse bosque, onde os dois amantes se escondem nuns arbustos. Ao ver as folhas mexerem-se, Cíquiro lança a sua azagaia e mata Antipe. Quando se apercebe do que cometeu, monta novamente no cavalo e lança-o contra as rochas, matando-se.

Os habitantes da Caónia cercam esse sítio com muros e chamarão Cíquiro à cidade assim fundada.

Motivo: dolor

Modo: precipitação

Temas: amor desigual, caça, Caónia, engano, mito etiológico, mito epónimo, sexo prématrimonial

Fontes:

BNP (não consta)

Grimal s.v. Cichyros 92

RE s.v. Kichyros $377 \mathrm{n}^{\circ} 1$

[Van Hoof: não regista)

\section{CLEOBEIA}

$\mathrm{Na}$ corte de Fóbio, tirano de Mileto, vive como refém um jovem nobre, de seu nome Anteu de Halicarnasso. Cleobeia, a rainha, apaixona-se por ele, mas Anteu evita-a a todo o custo. Argumenta que tem medo de ser descoberto e invoca também o respeito pela hospitalidade de Fóbio. Cleobeia decide então vingar-se. Atira uma taça de ouro a um poço e pede a Anteu que vá buscá-la. Quando Anteu se encontra lá no fundo, Cleobeia lança-lhe uma pedra que o mata. Por remorso, enforca-se.

Motivo: conscientia

Modo: forca

Temas: adultério feminino, hospitalidade, dolo feminino, Mileto

Fontes:

BNP s.v. Cleoboea 428

Grimal s.v. Anthée 3

RE s.v. Kleoboia 669-670 n ${ }^{\circ} 5$

[Van Hoof s.v. Kleoboia: mala conscientia, hanging, +, Parthenios Er.Path. 14,4)

\section{CLEOMEDES}

$\mathrm{Na} 71^{\text {a }}$ Olimpíada, o pugilista Cleomedes de Astipaleia mata o adversário, Iço, de Epidauro. É desclassificado e enlouquece. No ginásio local, provoca um acidente onde morrem 60 crianças. Fugindo para não ser lapidado, refugia-se no templo de Atena. Esconde-se numa arca no santuário e fecha-a. Quando a conseguem abrir, tinha desaparecido.

É instituído um culto em sua honra.

Motivo: furor

Modo: ?

Temas: Astipaleia, Epidauro, Jogos Olímpicos, metamorfose, mito etiológico Fontes: 
BNP (não consta)

Grimal s.v. Cléomédès 95 (não refere suicídio, mas desaparecimento)

RE s.v. Kleomedes 679-694 $\mathrm{n}^{\circ} 4$ (desaparece)

Pausânias 6.9.6-8 (desaparece)

[Van Hoof s.v. Kleomedes: furor, weapons, +, Her. 6,75]

CLEÓPATRA (ver Alcínoe e Alteia)

Filha de Idas e mulher de Meleagro, rei da Etólia. Quando o marido morre, vítima do incêndio atiçado por Alteia (ver Alteia), enforca-se.

Motivo: dolor

Modo: forca

Temas: amor conjugal, Etólia, perda de marido, intervenção feminina

Fontes:

BNP s.v. Cleopatra 438 n 2 (no episódio de Meleagro, onde convence o marido, Meleagro, a pôr de parte a sua raiva e a reentrar na batalha, tem o mesmo papel que Pátroclo na história de Aquiles)

Grimal s.v. Cleópâtra 95 n²; s.v. Méléagre 284

RE s.v. Kleopatra $732-789 \mathrm{n}^{\circ} 3$

Apolodoro, 1.8.3 (forca; mito etiológico; carpideiras transformadas em aves)

Higino, Fab. 174 diz que a esposa de Meleagro se matou, recebendo o nome de Alcíone

Pausânias, 4.2.7

[Van Hoof: não consta; a que consta é a rainha do Egipto, s.v. Kleopatra: pudor, poison, +, Vell. $2,87,2]$

\section{CLEÓSTRATO}

Para livrar a cidade de Téspias de um dragão a quem era feito sacrifício anual de um jovem, Cleóstrato veste uma armadura metálica com uma espécie de harpões ou anzóis, e, pela sua iniciativa, ao ser comido pelo dragão, provoca-lhe a morte. O nome significa 'Combate glorioso'.

Motivo: devotio

Modo: precipitação

Temas: dragão, mito epónimo, sacrifício voluntário masculino, Téspias

Fontes:

BNP (não consta)

Grimal s.v. Cléostratos 95

RE s.v. 806 (não consta esta lenda)

Pausânias, 9.26.7

[Van Hoof: não regista]

\section{CLÍCIE (ou CLÍCIA)}

Clície é amante de Hélio (ou Sol), que a troca por Leucótoe, filha do rei Órcamo, da Pérsia. Ao ser preterida, denuncia Leucótoe ao pai desta, que enterra a filha viva. Hélio, todavia, nunca mais visita Clície. E esta, nove dias sem comer, morre de pesar e é transformada em heliotrópio (ou girassol).

Motivo: conscientia

Modo: inedia 
Temas: Ásia (Pérsia), Hélio, metamorfose, mito etiológico, repressão sexual

Fontes:

BNP s.v. Clytia, Clytie 488 n³ (“dies from sorrow”); s.v. Leucothoe 451-452

Grimal s.v. Clytia 97 (erro: "Clytie fut enfermée dans une fosse profonde, où elle mourut ...

Leucothoé en fut punie); s.v. Leucothoé 262 (transformada em heliotrópio)

RE s.v. Klytia, Klytie 893 n² (Alpenveilchen 'ciclame'); s.v. Leukothoe 2306

Higino, Fábulas, 14 e 20 (nada diz; indicação errónea de Grimal)

Ovídio, Met. 4.206-270; v.256-270 (torna-se flor semelhante a violeta)

[Van Hoof: não regista]

\section{CLÍMENO (ver Harpálice)}

Filho de Esqueneu, ou de Teleu, rei da Arcádia. Clímeno apaixona-se pela sua filha Harpálice e, com a cumplicidade da ama, consegue unir-se a ela. Depois, dá-a em casamento a Alastor, mas arrepende-se e toma-a de novo. Harpálice vinga-se. Mata os seus irmãos mais novos (ou então a criança que teve da relação incestuosa), e dá-os a comer a seu pai. Compreendendo o sucedido, Clímeno mata a filha e suicida-se.

Segundo outra versão, é transformado em ave.

Motivo: pudor

Modo: ?

Temas: antropofagia, Arcádia, incesto, metamorfose, perda de filhos

Fontes:

BNP s.v. Clymenus 486-487 nº (refere a violação de Harpálice); s.v. Harpalyce 1148 n²

Grimal s.v. Clyménos 96 n³ Harpalycé 174-175 nº 2

RE Harpalyke 2403-4044 no 3; s.v. Klymenos 881-882 n²

Higino, Fábulas, 206, 242.4 (mata-se pelo incesto)

[Van Hoof s.v. Klymenos: pudor, ?, +, Hyg.Fab. 242,4]

\section{CLITE}

A jovem é filha do adivinho Mérope de Percote, na Mísia, e mulher de Cízico, rei dos Dolíones, na Propôntida, Ásia. Tendo acolhido os Argonautas logo após o casamento, quando estes partiram e foram novamente lançados à costa por uma tempestade, os Dolíones julgaram tratar-se de ataque de piratas e pegaram em armas. Na refrega, o rei Cízico é morto pelo argonauta Jasão. Desesperada, Clite enforca-se.

Motivo: dolor

Modo: forca

Temas: amor conjugal, Argonautas, Ásia, perda do marido

Fontes:

BNP s.v. Cleite 421

Grimal s.v. Clité 96; s.v. Cyzicos 112

RE s.v. Kleite $655-656 \mathrm{n}^{\circ} 1$

[Van Hoof s.v. Kleite: dolor, hanging, +, Parthenios, Er.Path. 28,2]

\section{CODRO}

De origem messénia e filho de Melanto, Codro sucedeu a seu pai como rei de Atenas. Em guerra com os Atenienses, os Peloponésios consultaram o oráculo de Delfos, que garantia a vitória na condição de não matarem o rei de Atenas. Conhecedor do oráculo, e para garantir a salvação da cidade, Codro sai da cidade disfarçado de mendigo ou 
lenhador e provoca os dois primeiros inimigos que lhe aparecem pela frente, sendo morto. $\mathrm{O}$ seu túmulo ficava no exterior, às portas da cidade. Provavelmente o mito ajudava a explicar essa localização.

Motivo: devotio

Modo: arma

Temas: Atenas, disfarce, provocatio, Messénia, mito etiológico, oráculo

Fontes:

BNP s.v. Codrus 503

Grimal s.v. Codros 98 ; sv. Alétès 28

RE s.v. Kodros 984-994 (Opfertod)

[Van Hoof s.v. Kodros: devotio, provocation, +, Lykourgos, Kata Leokratous]

CORESSO (ver Calírroe 2)

Coresso, sacerdote de Dioniso, apaixona-se por Calírroe, que não lhe corresponde. Perante os lamentos do apaixonado, o deus envia uma peste que só será amainada com o sacrifício de Calírroe, ou de um substituto, oficiado por Coresso. Nem os pais aceitam substituir Calírroe. Mas quando Coreso vai sacrificá-la, falta-lhe a coragem, o amor sobrepõe-se, e degola-se a si próprio no altar. Nesse momento, Calírroe também se degola junto de uma fonte que toma o seu nome.

Motivo: devotio

Modo: arma

Temas: desamor, Dioniso, hidrónimo, mito epónimo, oráculo, suicídio duplo

Fontes:

BNP (não consta)

Grimal s.v. Callirhoé $76 \mathrm{n}^{\circ} 5$

RE (não consta)

Pausânias, 7.21.1-5

[Van Hoof s.v. Koresos: dolor, weapons, +, Paus. 7,21,1]

\section{CORÓNIDES}

Em Orcómeno, na Beócia, surge uma epidemia. Duas irmãs, Metíoca e Menipa, filhas de Corónis e de Oríon, oferecem-se como vítimas às divindade infernais. Recebem um culto onde anualmente são sacrificados animais. São transformadas em cometas.

Motivo: devotio

Modo: arma

Temas: mito epónimo, Beócia, Hades, sacrifício feminino, sacrifícios humanos, suicídio colectivo, astronomia

Fontes:

Grimal s.v. Coronides 100

RE s.v. Koronis 1431-1434

[Van Hoof: não regista] 


\section{CREÚSA 1 (ou GLAUCE)}

Creúsa, ou Glauce, é filha de Creonte, rei de Corinto. Quando fica noiva de Jasão, Medeia envia-lhe presentes envenenados que lhe provocam dores por combustão. Creúsa atira-se a uma fonte e afoga-se.

A fonte passa a ter o nome de Glauce.

Motivo: impatientia doloris

Modo: afogamento

Temas: Corinto, Creonte, fonte, Jasão, Medeia

Fontes:

BNP s.v. Creusa 939-940 nº 3 (nada consta); s.v. Glauce 866 nº 2 (suicídio)

Grimal s.v. Créüse 103 n 3 (não menciona suicídio); s.v. Glaucé (remete para Creúsa, mas em nenhuma das entradas se diz algo pertinente)

RE s.v. Glauke 1394-1397 no 1 (fonte Glauce; suicídio) e no 5; s.v. Kreusa 1824-1826 n 2 (Náiade da Tessália), $n^{\circ} 4$ (idêntica a Glauke)

Higino, Fábulas, 25.3

Pausânias, 2.3.6

[Van Hoof: não regista esta personagem]

\section{CREÚSA 2}

É filha de Erecteu e de Praxítea. Violada por Apolo numa gruta da Acrópole de Atenas, onde expõe a criança, Íon, nascida do encontro. O menino vem a ser criado no templo de Delfos. Entretanto, Creúsa casa com Xuto, só tendo filhos quando visitam Delfos. Aqui dá-se um encontro e reconhecimento de Íon, matéria da tragédia homónima de Eurípides. No decurso da acção, Creúsa projecta suicidar-se mas dá-se um final feliz graças ao aparecimento da Atena, enviada por Apolo

Motivo: pudor

Modo: arma

Temas: Apolo, Atenas, Delfos, exposição de crianças, gruta, noverca, reconhecimento Fontes:

BNP s.v. Creusa 939-940 n 2 (nada consta)

Grimal s.v. Créüse 103 n 3 (não menciona suicídio)

RE s.v. Kreusa $1824-1826 \mathrm{n}^{\circ} 3$

Eurípides, Íon, 1061-1073 (coro refere que Creúsa planeia matar-se com espada ou forca) 15531618 (Atena revela a verdade)

[Van Hoof s.v. Kreusa: pudor, weapons, -, Eur.Ion. 1065]

\section{CRISIPO}

Crisipo é filho de Pélops e da ninfa Axíoca, ambos de origem asiática. Quando Laio é banido da corte tebana por Zeto e Anfíon, refugia-se na corte de Pélops, na região do Peloponeso, apaixona-se por Crisipo e rapta-o. Este, sob o peso da vergonha, suicida-se. Pélops amaldiçoa Laio, e será esta a origem da maldição dos Labdácidas.

Motivo: pudor

Modo: ?

Temas: Ásia, homo-erotismo, hospitalidade, maldição, mito etiológico, Peloponeso, Tebas

Fontes: 
BNP s.v. Chrysippus 288 n $^{\circ} 1$ (suicídio)

Grimal s.v. Chrysippos 91

Lexikon s.v. Chrysippos 2498-2500

RE s.v. Chrysippos 2498-2511 nº 1 ; s.v. Oidipus 2103-2117, esp.2109-2110

Higino, Fábulas, 85, 243

[Van Hoof: não regista)

CTÓNIA (ver Erecteu, filhas de)

[Van Hoof: não regista]

\section{DADA}

Dada é a mulher do herói cretense Sámon, que ajudou Escamandro a conquistar a Tróade. Depois de Sámon ser morto numa batalha, Dada pede a um arauto que a acompanhe até uma cidade próxima, onde ela pretende voltar a casar. No caminho, o arauto viola-a. Humilhada, Dada trespassa-se com a espada do seu marido, que trazia consigo. Quando os cretenses sabem da notícia, lapidam o arauto no local do crime, que toma o nome de Campo do Impudor.

Motivo: pudor

Modo: espada

Temas: Ásia, assédio sexual, Creta, espada, mito epónimo, corónimo, paralelo com Lucrécia, Tróia

Fontes:

BNP (não consta)

Grimal s.v. Dada 113

RE s.v. Dada 1977

[Van Hoof: não regista]

\section{DÁFNIS}

Filho de Hermes e de uma ninfa, Dáfnis é um semideus. Nasce na Sícilia, num bosque de loureiros dedicado às ninfas, o que explica o seu nome, que significa loureiro em grego. De grande beleza, Dáfnis é amado por deuses e humanos, mas é a ninfa Nómia, a Pastora, que tem o seu amor, com juras de fidelidade mútua e eterna.

A filha do rei da Sicília embebeda-o e consegue unir-se a ele. Nómia cega-o (nalgumas versões chega a matá-lo). Dáfnis, inventor da siringe, entoa canções de luto e, no seu desespero, lança-se do alto de um rochedo.

Associava-se a memória de Dáfnis a uma fonte e anualmente ofereciam-se sacrifícios em sua honra. Noutras versões: transforma-se em rochedo; é levado ao céu por Hermes, seu pai.

Motivo: pudor

Modo: precipitação

Temas: bucolismo, castigo da beleza, cegueira, desamor, engano, mito etiológico, paralelo com Castália, rito de iniciação, Sicília, sexualidade feminina, vinho

Fontes:

BNP s.v. Daphnis $83 n^{\circ} 1$ (honrado com rituais de lamentação, como os de Adónis. Na poesia bucólica era o ideal do pastor adolescente e criador das toadas pastoris)

Grimal s.v. Daphnis 117

RE s.v. Daphnis 2141-2147 no 1 
[Van Hoof: s.v. Daphnis 2: pudor, jumping, -, Longos 4,18]

DEJANIRA (ver Héracles)

Dejanira é filha de Alteia e de Eneu, rei de Cálidon (ou de Dioniso, noutra versão) e irmã de Meleagro. Quando Héracles desce ao Hades para procurar Cérbero, encontra a alma de Meleagro, que lhe pede que case com a sua irmã Dejanira, sozinha desde que ele morrera. Héracles e Dejanira casam-se e terão Hilo. Quando deixam Cálidon, encontram no caminho o Centauro Nesso, que tenta violar Dejanira. Héracles mata-o, mas, antes de morrer, Nessos consegue entregar a Dejanira o que diz ser um filtro de amor. Na realidade, esse filtro é uma droga: contém sangue que lhe escorrera da ferida mortal provocada por Héracles.

Depois de acolhidos em Tráquin pelo rei Céix, em cujas campanhas militares vem a participar, Héracles apaixona-se por Íole, que tomara como refém. Para reconquistar o amor do marido, Dejanira resolve utilizar o suposto filtro de amor. Tinge uma túnica com a droga que lhe havia dado Nesso e envia-a a Héracles. Mal este a veste, uma queimadura terrível destrói-lhe a pele. Héracles não consegue resistir ao sofrimento e acaba por se imolar no monte Eta. Quando vê o que provocou, Dejanira mata-se, seja com uma espada, seja pela forca.

Motivo: conscientia

Modo: arma

Temas: antecedentes familiares (mãe), Cálidon, catábase, filtros de amor, Héracles, magia

Fontes:

BNP s.v. Deianira 178

Grimal s.v. Déjanire 119

RE s.v. Deïaneira 2378-2381 nº (ambas as versões)

Diodoro Sículo, 4.36-38 (Dejanira enforca-se ao conhecer a sua hamartia 'culpa')

Higino, Fábulas, 36 (suicidou-se) 243.3 (matou-se)

Sófocles, Traquínias, 879-891 (com arma)

[Van Hoof s.v. Deianeira: pudor, weapons, +, Soph.Trach. 881; p.115-116: espada segundo Sófocles; forca segundo Higino (informação errónea)]

DICTE (ver Britomártis)

Nome alternativo de Britomártis, ninfa de Creta. Assediada por Minos, salta para o mar mas é salva por rede de pescadores.

Motivo: desperata salus

Modo: afogamento

Temas: assédio sexual, Creta, Minos, pesca, suicídio frustrado

Fontes:

BNP s.v. Dicte 375 (nada diz)

Grimal s.v. Dicté

RE s.v. Britomartis $880-881$; s.v. Diktynna $584-59$

[Van Hoof: não regista; regista em Britomartis-Diktynna] 


\section{DIDO 1}

A lenda de Dido, rainha de Cartago, está ligada à colonização fenícia do mediterrâneo ocidental.

Perseguida por seu irmão Pigmalião, que já tinha morto o seu marido e tio, Sicarbas, Dido foge de Tiro e estabelece-se em Cartago. Aqui, um rei indígena e vizinho, Iarbas, quer casar com ela e ameaça declarar guerra à cidadela de Cartago se ela o recusar. Pressionada, Dido pede um prazo de três meses, argumentando que a sombra do seu primeiro marido tem de ser apaziguada com sacrifícios. Quando o prazo expira, e para salvar a cidade, sobe para uma pira e mata-se.

Motivo: devotio

Modo: imolação pelo fogo

Temas: África, Ásia, Cartago, Fenícia

Fontes:

BNP s.v. Dido 389 (para salvar a cidade)

Grimal s.v. Didon 124; s.v. Sychée 432

RE s.v. Dido 426-433

[Van Hoof: não consta]

\section{DIDO 2}

A história contada na Eneida de Virgílio difere um pouco, mas Dido, rainha de Cartago, também se mata depois de se apaixonar por Eneias, que com ela vivera como príncipe consorte, e de este partir sem se despedir. Dido manda construir uma pira e pede a Ana, sua irmã, que lhe ateie fogo enquanto ela se mata com a espada que lhe fora oferecida por Eneias. No meio das chamas, lança imprecações contra Eneias e os troianos.

Quando, no Canto VI da Eneida, Eneias a reencontra no além, Dido vira-lhe costas e refugia-se nos braços do defunto marido, Siqueu, a quem havia jurado fidelidade.

\section{Motivo: exsecratio}

Modo: arma

Temas: Áfirca, Ásia, coadjuvante, Cartago, desamor, espada do amado, Fenícia, paralelo com Héracles sobre a pira, rainha,

Fontes:

BNP s.v. Dido 389 (segundo Varrão, é Ana que se imola por Eneias)

Grimal s.v. Didon 124; Sychée 432 (suicida-se por remorsos pela infidelidade a Siqueu).

RE s.v. Dido 426-433

Higino, Fábula, 243.7

[Van Hoof s.v. Dido: dolor, weapons, +, Verg.Aen. 4,642-692]

\section{DIMETES (ver Evópis)}

Depois da morte de Evópis, que lançara maldições sobre o marido (ver Evópis, de Trezena), Dimetes encontra na praia o cadáver de uma mulher muito bela, apaixona-se e une-se a ele. O cadáver decompõe-se e Dimetes constrói-lhe um túmulo. Não podendo suportar a dor desta perda, trespassa-se com a sua espada sobre o sepulcro.

Motivo: dolor

Meio: espada

Temas: amor macabro, fetichismo, necrofilia, suicídio sobre túmulo da amada, Trezena Fontes: 
BNP (não consta)

Grimal s.v. Dimoetès 125

RE s.v. Dimoites 649

[Van Hoof s.v. Dimoetes: dolor, weapons, +, Parthenios Er.Path. 31]

\section{DRÍMACO}

Os habitantes da ilha de Quios foram os primeiros a comerciar escravos, incorrendo na cólera dos deuses. Muitos dos escravos fogem para as montanhas e, liderados por Drímaco, vão destruindo as terras dos seus antigos donos. Depois de muitas investidas, os habitantes de Quios acabam por fazer um pacto com Drímaco, que, mediante um tributo, se compromete a não atacá-los mais. Com a cabeça a prémio, Drímaco, cansa-se de viver em sobressalto. Convence um jovem que ele ama a cortar-lhe a cabeça e a ir reivindicar o prémio junto dos habitantes de Quios. Depois da morte do seu líder, os escravos retomam a pilhagem. Então, os habitantes de Quios elevam um santuário a Drímaco, que, em sonhos, os avisa quando um escravo prepara alguma conjura contra o dono.

Motivo: taedium vitae

Modo: espada

Tópico: mito etiológico, revoltas de escravos, suicídio manu aliena

Fontes:

BNP (não consta)

Grimal s.v. Drimacos 129

RE s.v. Drimakos 1708

[Van Hoof: não consta]

ECO (ver Narciso 1)

$\mathrm{Na}$ versão de Ovídio, a ninfa Eco, quando se apaixona por Narciso, na Beócia, e é rejeitada, desespera e retira-se para a solidão das grutas, definhando até ser uma voz que geme.

Motivo: dolor

Modo: inedia

Motivos: Beócia, desamor, gruta, mito epónimo

Fontes:

BNP s.v. Echo 787-789 (versão de Ovídio); s.v. Narcissus 560-561

Grimal s.v. Narcisse 308-309; s.v. Écho 132-133

RE s.v. Echo 1926-1930; s.v. Narkissos 1721-1733 nº 1

Ovídio, Metamorfoses, 3.356-510

Pausânias, 9.31.7-9 (suicídio subentendido; admite paixão pela irmã; diz que a flor existia antes) [Van Hoof: não consta]

\section{ÉDIPO}

Pertence à família real Tebana. É filho de Laio. Sua mãe surge com vários nomes, um deles é Jocasta. Na lenda entrecruzam-se muitas versões. No seguimento de um oráculo, logo que nasce, Édipo é exposto e recolhido por pastores coríntios que o levam a Peribeia e Pólibo, rei de Corinto. Saílo da adolescência, vai interrogar o oráculo e fica a conhecer o seu destino: matar o pai (que ele acredita ser Pólibo) e casar com a mãe (que 
para ele é Peribeia). Querendo fugir à maldição, abandona a suposta casa paterna. Num cruzamento, Édipo mata Laio, seu pai natural, sem o saber (incerto se é antes ou depois da consulta do oráculo). Em Tebas, decifra o enigma da esfinge, que se suicida. Ao libertar Tebas do monstro, casa com a viúva do recém-falecido rei, Jocasta, sua mãe verdadeira. Mas uma peste assola a cidade. Consultado o oráculo através do adivinho Tirésias, e conhecidos os antecedenes de Édipo através de um pastor e de um mensageiro, dá-se a anagnórise e a consciencialização do incesto. Jocasta enforca-se. Édipo cega-se ou, segundo Higino, mata-se.

Motivo: pudor

Modo: ?

Temas: Corinto, Édipo, incesto, oráculo, Tebas

Fontes:

BNP s.v. Oedipus 44-48 (não refere suicídio)

Grimal s.v. Oedipe 323-324 (não refere suicídio)

RE s.v. Oidipus 2103-2117

Higino, Fábulas, 242.5 (suicidou-se depois de se cegar, por causa de sua mãe)

Sófocles, Rei Édipo, 1369

[Van Hoof s.v. Oidipous: pudor, ?,+, Hyg.Fab. 242,4 (errado); cf. p. 118: uma versão diz que se suicida ao saber do incesto; p.270, n.85 remete para Soph.OT. 1369: na verdade, Édipo recusa a ideia de suicídio]

\section{EGÉRIA}

Ninfa de Nemi, na proximidade de Roma, e esposa ou conselheira do rei Numa. Quando este desaparece, morre transformada em fonte, de tantas lágrimas verter. Tinha culto junto da Porta Capena, em Roma. Liga-se ao culto de Diana.

Motivo: dolor

Modo: inedia

Temas: amor conjugal, Itália, metamorfose, mito etiológico, perda de marido

Fontes:

Grimal s.v. Égérie 133

BNP s.v. Egeria 838-839 cita versão de Ovídio, Met. 15.478-551 (versão usada)

RE s.v. Egeria 1980-1981

Ovídio, Met. 15. 547-551

[Van Hoof: não consta]

\section{EGEU}

Teseu é filho de Egeu, o rei de Atenas. Retorna da expedição contra o Minotauro. Havia prometido içar as velas brancas se voltasse vivo. No caso de os navios tornarem sem ele, as velas seriam negras. Mas Ariadne, que ele tinha abandonado em Naxos, lança-lhe maldições que o desorientam e Teseu esquece-se de trocar as velas. Seu pai Egeu, que o aguardava na costa, ao avistar as velas negras, julga seu filho morto. Precipita-se ao mar que, desde então toma o seu nome, o Mar Egeu.

Motivo: dolor

Modo: afogamento

Temas: amor paternal, Atenas, Creta, engano, maldições, Minotauro, mito epónimo, navegações, perda de filho, sacrifícios humanos, Teseu 
Fontes:

BNP s.v. Aegeus 187-188 ("Many saw this as part of a collection of proofs, intended to link Aegeus to Poseidon, who likewise claimed fatherhood of Theseus").

Grimal s.v. Egée 133; s.v. Thésée 450-451

RE s.v. Aigeus, 952-956 n 1 (atirou-se da Acrópole e foi venerado como herói).

Higino, Fábulas, 43.2, 242.1

[Van Hoof s.v. Aigeus: desperata salus, jumping, + , Plout.Thes. 22]

\section{EGINETAS}

Irada por os Eginetas prestarem culto à sua rival Ártemis (ou divindade com ela identificada), Juno envia uma terrível peste que os dizima. Muitos, para fugirem à morte, enforcam-se (versão de Ovídio).

A lenda pode relacionar-se com a extrema riqueza histórica e religiosa da sobrepovoada ilha e com episódios vários de conquistas do seu território, com escravização e matança da população aprisionada, como em 424 a. C.

Motivo: desperata salus

Modo: forca

Temas: Egina, peste, suicídio em massa, vingança divina

Fontes:

Grimal não regista entrada

BNP não regista entrada

RE s.v. Aigina 964-968

Ovídio, Met. 7.517-660 (esp. 604-605)

Plutarco, Nícias, 6

Tucídides, 4.57

[Van Hoof s.v. Aeginetae: desperata salus, hanging, Ov.Met. 7.604]

ENDEIS (ver Alcíone 2)

[Van Hoof: não regista]

\section{ENONE}

Na sua juventude, Páris é afastado de Tróia e vive nas montanhas com a ninfa Enone, filha do deus-rio Cébren. Mas abandona Enone quando Afrodite lhe promete o amor de Helena. Durante o cerco de Tróia, é ferido por uma seta de Filoctetes. Lembrando-se da promessa de Enone - que saberia curá-lo de feridas - , vai ter com ela ou envia mensageiros pedindo ajuda. Mas a ninfa, irritada por ter sido abandonada, recusa o socorro da medicina que Apolo lhe ensinara em troca da sua virgindade. Finalmente arrepende-se, mas será tarde demais, já Páris havia morrido. Atordoada pelo remorso e pela dor, enforca-se ou precipita-se de uma torre ou atira-se à pira fúnebre.

Motivo: conscientia

Modo: forca

Temas: Apolo, Páris, medicina feminina, Guerra de Tróia, vingança, virgindade

Fontes:

BNP s.v. Oenone $54 \mathrm{n}^{\circ} 2$ (não refere meio)

Grimal s.v. Oenoné 327 (forca ou imolação)

RE s.v. Oinone $2251-2253 \mathrm{n}^{\circ} 2$

Apolodoro, 3.12.6 (arrependendo-se, enforcou-se) 
Ovídio, Her. 5 (só menciona abandono, regresso de Páris com Helena, ciúme de Enone, domínio das ervas medicinais).

[Van Hoof s.v. Oinone: dolor, hanging, +, Apoll. 3.12.6]

\section{ENTÓRIA, QUATRO FILHOS de}

O camponês Icário oferece hospitalidade a Saturno, que se une à filha deste, Entória. Dessa relação nascem 4 filhos: Jano, Himno, Fausto e Félix. Saturno ensina a Icário a arte de cultivar a vinha e de fazer vinho, recomendando-lhe que partilhe os novos conhecimentos com os vizinhos. Icário assim faz: convida os vizinhos e dá-lhes a beber o vinho, o que os faz cair em letargia. Quando acordam, julgam ter sido envenenados e lapidam Icário. Desgostosos, os seus quatro netos enforcam-se. Logo uma epidemia assola Roma, em consequência da cólera de Saturno, diz o oráculo de Delfos. Para acalmar o deus, Lutácio Cátulo funda o templo de Saturno, no sopé do Capitólio, e um altar ornado com as quatro caras dos filhos de Entória. Além disso, dá ao primeiro mês do ano a designação de Janeiro, provinda do nome de Jano, filho de Saturno e de Entória.

Trata-se de lenda romana tardia, relatada por Plutarco e relativa à fundação do templo de Saturno, cultuado em Itália.

Motivo: dolor

Modo: forca

Temas: amor filial, decoração de templo, Dioniso, Itália, mito etiológico, mito epónimo, paralelo com a lenda de Erígone, Saturno, vinho

Fontes:

Grimal s.v. Entoria 139; s.v. Erigoné $145-146$ nº

BNP (não regista entrada)

RE s.v. Entoria 2650

Plutarco, Obras Morais, 307ef

[Van Hoof: não regista]

\section{ERECTEU, FILHAS de}

Erecteu é um herói ateniense e o seu mito está ligado às origens de Atenas, onde tem um culto importante. É filho de Hefesto e da Terra. Entrará na genealogia dos primeiros reis de Atenas como filho de Pandíon I e de Zeuxipe, irmão de Butes, de Filomela e Procne, conhecidos pela sua metamorfose em aves.

À morte de Pandíon, Erecteu sucede-lhe e Butes fica sacerdote de Atena e Posídon, as duas divindades protectoras de Atenas. Erecteu casa com Praxítea, filha de Frásimo e de Diogeneia.

Durante uma guerra travada entre os Atenienses e os habitantes de Elêusis, estes aliamse ao Trácio Eumolpo, filho de Posídon e de Quíone, bisneto de Erecteu. O herói pergunta ao oráculo de Delfos como podem sair vitoriosos. O oráculo responde que Erecteu deverá sacrificar uma das suas filhas (a filha mais nova). Retornando a Atenas, e dependendo das versões, sacrifica Ctónia ou Protogenia. Mas as irmãs (cujo número varia de versão para versão) tinham feito o juramento de que não sobreviveriam após a sua morte e suicidam-se.

Numa outra versão, elas matam-se em prol do interesse da pátria. Erecteu e os atenienses saem vitoriosos.

Motivo: devotio 
Modo: arma

Temas: amor fraternal, Atenas, devotio, fides, mito etiológico, perda de irmã, sacrifício feminino, suicídio colectivo

Fontes:

BNP s.v Erechteus 21

Grimal s.v. Érechthée 143; s.v. Chthonia 92 no 2 (suicida-se com as irmãs, depois de Protogenia ter sido sacrificada); versão inglesa s.v. Chthonia ("she killed herself and her sisters"); s.v. Créüse 103

RE s.v Erechtheus 404-411 no 1; s.v. Chthonia 2522-25233 n 4 (sacrificada pelo pai, por indicação do oráculo)

Apolodoro, 3. 15.4-5 (haviam jurado morrer juntas; trad. Loeb)

Higino, Fábulas, 46.4 (Ctónia é sacrificada pelo pai em vez do irmão; as irmãs cumprem o juramento e matam-se), 238 (Ctónia sorteada)

[Van Hoof s.v. Erechthei filiae: fides, weapons, +, Apoll. 3,15,4,5]

\section{ERÍGONE 1}

Filha de Egisto e Clitemnestra. Na presente versão, consegue que Orestes seja levado a julgamento no tribunal do Aerópago. Mas Orestes é absolvido. Despeitada, Erígone enforca-se.

Motivo: pudor

Modo: forca

Temas: Areópago, Atenas, Orestes, intervenção feminina

Fontes:

BNP s.v. Erigone $32 \mathrm{n}^{\circ} 2$

Grimal s.v. Érigoné $145 \mathrm{n}^{\circ} 2$

RE s.v. Erigone 450-452 n 1 (aus Gram 'por despeito'); s.v. Orestes 987 (forca)

[Van Hoof: não regista]

\section{ERÍGONE 2}

Icário, ateniense, dá hospitalidade a Dioniso quando ele traz aos homens a sabedoria da vinha e do vinho. Dioniso apaixona-se por Erígone, filha de Icário, e têm um filho, o herói Estáfilo. Dioniso oferece a Icário um odre de vinho, incentivando-o a partilhá-lo com os seus vizinhos pastores. Mas eles embebedam-se e julgam que Icário os envenenou. Matam-no à paulada e abandonam o cadáver. $\mathrm{O}$ seu cão, Mera, pelo ladrar, revela a Erígone o sítio onde se encontra o cadáver do pai, privado de sepultura. Desesperada, Erígone enforca-se na árvore ao pé da qual está o corpo. Todos seriam transformados em constelações.

Motivo: dolor

Modo: forca

Temas: amor filial, Atenas, Dioniso, paralelo com Antígona, sepultura, vinho

Fontes:

BNP s.v. Erigone $32 \mathrm{n}^{\circ} 1$

Grimal s.v. Érigoné $145 \mathrm{n}^{\circ} 1$; s.v. Maera 274

RE s.v. Erigone $450-452$ n 2

Higino, Fábulas, 130, 243.5

[Van Hoof s.v. Erigone: dolor, hanging, Apoll. 3,14,7,3; cf. p.105, onde a inclui nos suicídios por dolor: "A mother's death alone is no reason for children to kill themselves — in the case 
of Ilione both parents were dead. The mythical example of a daughter who follows her father in death is Erigone"]

\section{ERÍGONE 2, COMPANHEIRAS de (ver Erígone 2)}

Quando Erígone se enforca na árvore ao pé da qual encontra o corpo do seu pai, Dioniso vinga-se, enviando aos atenienses um terrífico flagelo: enlouquecidas, as raparigas de Atenas enforcam-se. O oráculo de Delfos é então consultado: o deus estaria a vingar a morte de Icário e de Erígone. Os pastores são punidos e institui-se em Atenas o festival dos Aiora, durante a qual se suspendem raparigas às árvores, mais tardes simples efígies.

Motivo: furor

Modo: forca

Temas: Atenas, Dioniso, folclore, mito etiológico, suicídio colectivo

Fontes:

BNP s.v. Erigone $32 \mathrm{n}^{\mathrm{o}} 1$; s.v. Aiora 406-407

Grimal s.v. Érigoné $145-146 n^{\circ} 1$; s.v Maera 274

RE s.v. Erigone $450-52 \mathrm{n}^{\circ} 2$

Higino, Fábulas, 130.3

Higino, Astronomia, 2.4-5

[Van Hoof: não regista]

\section{ERISÍCTON}

Herói da Tessália, não temia os deuses. Incorre em hybris quando corta um bosque sagrado consagrado a Deméter. Apodera-se dele uma fome insaciável e terrível. É esse o castigo da deusa.

Em poucos dias, o sacrílego Erisícton devora todo o seu patimónio. A sua filha Mestra, que tinha sido amante de Posídon e deste havia recebido o dom de se metamorfosear, vende-se como escrava e depois, tomando nova forma, revende-se novamente. Por esta via, consegue prover ao sustento do pai. Mas Erisícton, na sua loucura, acaba por se devorar a si próprio.

Motivo: furor

Modo: inedia

Temas: Deméter, gula, hybris, metamorfose, paralelo com Cambles, Posídon, Tessália, vingança divina, pantofagia.

Fontes:

BNP s.v. Erysichton 53

Grimal s.v. Érysichton $148 \mathrm{n}^{\circ} 1$ (filha Mnestra); s.v. Mestra 294

RE s.v. Erysichton $571-574 \mathrm{n}^{\circ} 1$

Ovídio, Met. 8. 725-884 (v. 8.848 e 871-874: é Erisícton que vende e revende a filha)

[Van Hoof: não consta]

\section{ÉSACO}

Ésaco é filho de Príamo e de Arisbe. Herda do avô Mérope o legado de interpretar os sonhos. Quando a sua mulher Hécuba está na iminência de dar à luz, Páris sonha que nascerá uma tocha inflamada que incendiará Tróia e as florestas de Ida. Ésaco é 
chamado a desvendar a mensagem deste sonho. Revela que o nascituro causará a ruína da cidade. Aconselha a darem-lhe morte à nascença.

Pouco depois, a mulher de Ésaco morre, picada por uma serpente. Ésaco atira-se ao mar. Com pena, Tétis transforma-o em mergulhão (lat. mergus).

Motivo: dolor

Modo: afogamento

Temas: amor conjugal, Ásia, metamorfose, perda de mulher, serpente, sonho, Tróia

Fontes:

BNP (não regista)

Grimal s.v. Aesacos 16

RE s.v. Aisakos 1046

[Van Hoof: não consta]

\section{ESCÉDASO}

Escédaso, de Leuctros, tem duas filhas, Hipo e Mólpia, que são violadas por dois lacedemónios, Frurárquidas e Parténio. Humilhadas, enforcam-se. O seu pai, Escédaso, tenta obter junto dos espartanos o castigo dos culpados. Sem esperança de alcançar justiça, suicida-se, invocando as Erínias e amaldiçoando Esparta. Ficou consagrada a expressão Skedasou katara 'maldições de Escédaso'.

Motivo: exsecratio

Modo: ?

Temas: Esparta, mito etiológico, Erínias

Fontes:

BNP (não regista)

Grimal s.v. Hippo 211

RE s.v. Skedasos, $465-468$

Pausânias 9.13.5 (não indica o meio)

Plutarco, Obras Morais, 773b-774c (foram mortas pelos violadores)

[Van Hoof s.v. Skedasos: exsecratio, ?, Plout.Mor. 774B]

\section{ESCÉDASO, FILHAS de (Hipo e Mólpia)}

Em Leuctros, Escédaso tinha duas filhas, Hipo e Mólpia, que são violadas por dois lacedemónios, Frurárquidas e Parténio. Em consequência, enforcam-se.

Motivo: pudor

Modo: forca

Temas: Esparta, estupro, suicídio colectivo

Fontes:

BNP s.v. Hippo (não refere)

Grimal s.v. Hippo 211

RE s.v. Skedasos, $465-468$

Pausânias 9.13.5

[Van Hoof s.v. Skedasi et Leuctri filiae: pudor, hanging, +, Diod. 15,53,3; p.117: castidade interessa ao bem-estar social] 


\section{ESFINGE}

A Esfinge é um monstro feminino. Tem a forma de uma mulher, o peito, as patas e a cauda de um leão e as asas de uma árvore de rapina. Assola a região de Tebas matando os viajantes que não decifram os enigmas que lhes coloca.

Mas Édipo resolve o enigma da Esfinge e o monstro atira-se do alto do rochedo onde se encontra.

Motivo: pudor

Modo: precipitação

Temas: esfinge, hibridismo, perigos das viagens, Tebas

Fontes:

BNP s.v. Sphinx 733

Grimal s.v. Sphinx 428; s. v. Créon 101-102 nº 2

RE s.v. Sphinx 1723

Diodoro Sículo, 4.64.4

Higino, Fábulas, 67.5

[Van Hoof s.v. Sphinx: pudor, jumping, +, Diod. 4,64,4]

\section{ESMIRNA (ver Mirra)}

ÉSON (ver Alcímede; ver Jasão)

Éson é filho de Creteu e de Tiro, pai de Jasão. O seu meio-irmão Pélias retira-lhe o reino de Iolcos, que Creteu lhe havia legado, e envia Jasão à conquista do velo de ouro. Quando se espalha a notícia de que os Argonautas haviam perecido, Pélias decide matar Éson. Mas este implora ser ele a escolher a forma de morrer e envenena-se com sangue de touro.

Motivo: necessitas

Modo: veneno

Temas: Argonautas, Iolcos, Jasão, ódio fraternal

Fontes:

BNP s.v Aeson 254-255 nº 1 (fontes sobre suicídio: Apolodoro, Diodoro Sículo, Valério Flaco)

Grimal s.v. Aeson 16

RE s.v. Aison 1086-1087 n 3 (várias versões da morte: ou voluntariamente ou obrigado)

Apolodoro, 1.9.27

Diodoro, 4.50 (Pélias força o pai de Jasão a beber sangue de touro; a mãe de Jasão, Anfínome, lança maldição e mata-se com espada)

Valério Flaco, 1.761-818 (chorando o filho, Alcímede decide morrer com o marido por ingestão de sangue de touro)

[Van Hoof: não regista]

\section{ESTENEBEIA (cf. Anteia)}

Estenebeia, que aparece em Homero com o nome de Anteia, é mulher do rei Preto e o casal habita em Tirinte. Os filhos são Megapentes e as Prétides. Estenebeia é seduzida pela beleza do recém-chegado Belerofonte, mas o jovem recusa os seus avanços. Estenebeia calunia-o perante Preto de ter tentado violá-la. Este, que não pode matá-lo devido a um interdito religioso (tinha-o purificado de um homicídio), e por afeição, envia-o para a Lícia com uma carta dirigida ao sogro, Ióbates, onde pede que mate o seu 
portador. Mas, por novo interdito (deveres de hospitalidade), Ióbates em vez de o matar, destina-lhe vários trabalhos perigosos, como matar a Quimera. Belerofonte escapa ao destino e volta a Tirinte para se vingar das calúnias. Estenebeia tenta fugir montada no cavalo Pégaso mas Belerofonte fá-la cair no mar (versão homérica, com paralelo em Eurípides).

Higino diz que Estenebeia se suicida por amor a Belerofonte, ou quando sabe que este casou (Fab.243), ou vai casar com a sua irmã, como prémio por ter morto a Quimera (Fab.57). Segundo um escólio às Rãs de Aristófanes, bebeu cicuta.

Motivo: dolor

Modo: afogamento

Temas: adultério, amizade, beleza, carta, desamor, hospitalidade, interditos religiosos e culturais, paralelo com Fedra / Hipólito, Quimera, vingança feminina

Fontes:

BNP s.v. Stheneboea 832; s.v. Bellerophontes, Bellerophon 587-588

Grimal s.v. Sthénébée 429; s.v. Bellérophon 64-65 (interdito religioso)

RE s.v. Stheneboia 2468 (fala em furor curado, não refere suicídio); s.v. Bellerophon 241-251, esp. 250-251 (versão do suicídio)

Higino, Fábulas, 57 (casamento com a segunda irmã foi reconhecimento por ter matado a Quimera), 243.2 (suicida-se por amor)

[Van Hoof s.v. Stheneboia: dolor, ?, +, Hyg.Fab. 57,5]

\section{ESTRÍMON}

Estrímon, filho de Oceano e de Tétis, é rei da Trácia. Quando o seu filho Reso é morto em Tróia, Estrímon, desesperado, atira-se ao rio Palestino, que passa a ter o seu nome.

Motivo: dolor

Modo: afogamento

Temas: amor paternal, Guerra de Tróia, hidrónimo, Trácia, Tróia

Fontes:

BNP s.v. Strymon 889 (não refere mito)

Grimal s.v. Strymon 431

RE s.v. Strymon 390-394 n²

[Van Hoof: não regista]

\section{ETRA}

Filha de Piteu, rei de Trezena, mãe de Teseu. Na versão de Higino, suicida-se devido ao desgosto causado pela morte do(s) filho(s).

Motivo: dolor

Modo: ?

Temas: amor maternal, Teseu, Trezena, sexualidade dos deuses

Fontes:

BNP s.v. Aethra 271 (não refere suicídio)

Grimal s.v. Aethra 17 (não refere suicídio)

RE s.v. Aithra 1107-1109 no 1 (suicídio, Hyg. Fab. 243)

Higino, Fábulas, 243.2 (morte de filhos)

Pausânias, 2.33 (não refere morte)

[Van Hoof s.v. Aithra: ?, dolor, +, Hyg.Fab. 243,2] 


\section{EUFRATES}

Eufrates tem um filho chamado Axurtas. Um dia encontra o filho adormecido ao pé de sua mãe. Pensando tratar-se de um estranho, mata-o. Descoberto o equívoco, atira-se ao rio Medo, que passa a chamar-se Eufrates.

Motivo: dolor

Modo: afogamento

Temas: amor paternal, Assíria, engano, mito epónimo, hidrónimo, perda de filho

Fontes:

BNP s.v. Euphrates $185-187$ (nada diz)

Grimal s.v. Euphratès 151

RE s.v. Euphrates, 1295-1216, esp. 1215-1216, $\mathrm{n}^{\circ} 2$ (Eufrates era filho de Arandakes); s.v. Xarandas 1408

[Van Hoof s.v. Euphrates: inpatientiae doloris, poison, +, Cass.Dio 69,8,3]

\section{EUQUENOR}

Neto do célebre adivinho coríntio homónimo, anuncia a seu filho Euquenor que este morrerá em sua casa de doença ou na Guerra em Tróia. Euquenor prefere partir para a guerra. É atingido por uma seta de Páris.

Motivo: necessitas

Modo: arma

Temas: Corinto, destino, provocatio, Guerra de Tróia, suicídio manu aliena

Fontes:

BNP s.v. Polyidus 527

Grimal s. v. Euchénor 149; s.v. Polyidos 385

RE s.v. Euchenor 881; s.v. Polyidos 1648-1662

[Van Hoof: não consta]

\section{EURÍDICE}

Eurídice é mulher de Creonte, rei de Tebas. A dor pela perda do filho Hémon, que se matara por Antígona, leva-a a enforcar-se.

Motivo: dolor

Modo: forca

Temas: amor maternal, Antígona, Creonte, perda de filho, suicídio solidário, Tebas

Fontes:

BNP s.v. Antigone 745-746 no 3; s.v. Eurydice (não regista esta personagem)

Grimal s.v. Eurydice $152 \mathrm{n}^{\circ}$ 5; s.v Antígona 38 "enfermée vivante dans le tombeau des Labdacides"

RE s.v Eurydike $1322-1327 \mathrm{n}^{\circ} 5$

Sófocles, Antígona, 1263, 1282-1283 (suicidou-se com arma), 1301-1305 (trespassa-se junto de um altar, lançando maldições sbre Creonte), 1315-1316

[Van Hoof s.v. Euridyke Creontis uxor: dolor, weapons, +, Soph.Ant. 1282, 1315]

\section{EVADNE}

Capaneu, filho de Hipónomo, é um dos sete princípes Argivos que integram a expedição dos Sete contra Tebas. Não teme os deuses e, no primeiro ataque à cidade, quer incendiá-la. Os raios de Zeus param-no no momento em que vai escalar o muro de 
Tebas e castigam a sua hybris com a morte. A sua mulher Evadne, filha de Ífis, lança-se na pira onde o corpo de Capaneu é incinerado.

Motivo: dolor

Modo: imolação pelo fogo

Temas: amor conjugal, hybris, perda do marido, Sete Contra Tebas, Tebas, Zeus

Fontes:

BNP $242 n^{\circ} 2$

Grimal s.v. Capanée 78; s.v. Évadné 155 n $^{\circ}$ 2; s.v. Iphis $236-237$ I n $^{\circ} 1$

RE s.v. Euadne $818 \mathrm{n}^{\circ} 2$

Higino, Fábulas, 243.2

Propércio, 1.15.17-18

[Van Hoof s.v. Euadne Kapanei filia: dolor, fire, +, Eur.Hik. 1016]

\section{EVENO}

Eveno é rei da Etólia, filho de Ares e de Demonice. Matava todos os pretendentes da sua filha Marpessa e ornava o templo de Posídon com os seus crânios. Mas Idas rapta Marpessa e oferece-a a Apolo. Eveno persegue Idas, que foge no carro alado oferecido por Posídon. Não o conseguindo apanhar, Eveno mata os seus cavalos e afoga-se no rio Licornas, que desde então se chama Eveno.

Motivo: pudor

Modo: afogamento

Temas: Etólia, mito hidrónimo, Posídon, virgindade guardada pelo pai

Fontes:

BNP s.v. Evenus $248-249 \mathrm{n}^{\circ} 3$ (nada diz)

Grimal s.v. Événos 156; s.v. Idas 226-227 (mito etiológico comparável ao de Hipodamia relativo aos Jogos Olímpicos)

RE s.v. Euenos 974-977 nº 3

Higino, Fábulas, 242.1

[Van Hoof s.v. Euenos: pudor, jumping, +, Hom.Il.Schol. 9,557-558]

\section{EVÓPIS (cf. Dimetes)}

Dimetes, irmão de Trézen, casa com a sua sobrinha Evópis, filha de Trezeno. Mas Evópis ama o seu próprio irmão. Dimetes apercebe-se e conta a Trézen. Descoberto o segredo, toldada pela humilhação e pelo medo, Evópis enforca-se, lançando maldições sobre Dimetes.

Motivo: exsecratio

Modo: forca

Temas: desamor, incesto, Trezena

Fontes:

BNP (não regista entrada)

Grimal s.v. Dimoetès 125

RE s.v. Euopis 1158-1159

[Van Hoof s.v. Euopis: pudor, hanging, +, Parthenios Er.Path. 31] 


\section{FÁSIS}

Ocírroe é o nome de várias ninfas e de divindades relacionadas com a água e as fontes. Neste caso, é uma das filhas de Oceano. Esta Oceânide une-se a Hélio e geram um filho, Fásis. Este surpreende-a um dia com um amante e mata-a. Perseguido pelas Erínias, atira-se ao rio Arcturo, que passa a chamar-se Fásis (o Faso).

Motivo: furor

Modo: afogamento

Temas: adultério, Erínias, Hélio, mito epónimo, hidrónimo, mito etiológico

Fontes:

BNP s.v. Phasis $941 \mathrm{n}^{\circ} 1$ (nada diz)

Grimal s.v. Ocyrrhoé 322, no 1; s.v. Phase 365

RE s.v. Phasis 1886-1898 (não refere mitónimo); s.v. Okyrrhoë 2394-2395 nº1

[Van Hoof: não regista]

\section{FEDRA}

Hipólito é filho de Teseu e da Amazona Hipólita (ou Melanipo ou Antíopa). Da mãe herda o gosto pela caça e pelos bosques. Despreza Afrodite e a divindade dilecta é Ártemis, deusa da caça. Afrodite vinga-se então de Hipólito suscitando em Fedra, a segunda mulher de Teseu, uma paixão proibida pelo seu enteado. Mas Hipólito é avesso a mulheres e recusa-a. Temendo que o enteado a denuncie a Teseu, Fedra acusa Hipólito de tentar violentá-la. Os seus intentos são alcançados. Teseu enche-se de raiva para com o filho e quere-o morto. Para não ser ele a executar a sentença emocional, recorre a Posídon, que lhe havia prometido cumprir três desejos que formulasse. O deus envia então um monstro marinho que se lança sobre Hipólito enquanto este conduz o seu carro em Trezena, à beira-mar. Os cavalos assustam-se, Hipólito cai, é arrastado até aos rochedos, preso pelos pés nas rédeas, e morre. Fedra, desesperada, invadida pelos remorsos, enforca-se.

Motivo: conscientia

Modo: forca

Temas: Afrodite, misoginia, theriodes bios, vingança divina, Trezena

Fontes:

BNP s.v. Phaedra 894 (Fedra suicida-se quando o seu amor por Hipólito se torna público)

Grimal s.v. Phèdre 365; s.v. Hippolyte 212-213

RE s.v. Phaidra $1543-1552 \mathrm{n}^{\circ} 1$

Eurípides, Hipólito, 275-277 (há nove dias sem comer, suicídio frustrado por inedia) e 723-731 (projecta suicídio com exsecratio)

Higino, Fábulas, 243.5

Séneca, Fedra, 258-266 (ameaça de suicídio dissuadido pela ama); 868 ss: projecta suicídio; 893: pudor; 1197-1200 (mata-se com a espada, por mala conscientia)

[Van Hoof s.v. Phaidra 1: dolor, inedia, -, Eur.Hip. 277]

[Van Hoof s.v. Phaidra 2: pudor, hanging, +, Eur.Hip. 726]

\section{FÉNIX}

A ave Fénix, quando sente que a morte está próxima, forma um ninho com plantas aromáticas, incenso e amomo. Numa das tradições, a Fénix deita-se sobre o ninho e morre, impregnando-se da sua semente, donde nasce uma nova Fénix. Na outra, provoca a combustão desse ninho para renascer das cinzas. 
Motivo: taedium vitae

Modo: imolação pelo fogo

Temas: autocombustão, eternidade, eterno retorno, eutanásia, fogo purificador, morte e vida, paralelo com Hiperbóreos, ressurreição

Fontes:

BNP s.v. Phoenix 170-174 nº5 (autocombustão)

Grimal s.v. Phénix 365-366

RE s.v. Phoinix 386-436 n5, p. 414-423 (símbolo da eternidade)

[Van Hoof: não regista]

\section{FÍLIS}

Quando regressa de Tróia, Demofonte (ou seu irmão Acamante), filho de Teseu e de Fedra (noutras versões, de Teseu e de Ariana), naufraga na Trácia, perto da foz do Estrímon. A princesa local, Fílis, filha de Cíaso (ou Licurgo, ou Fileu), rei de Anfípolis, apaixona-se pelo hóspede que seu pai protegera. Quando Demofonte decide viajar para Atenas, prometendo voltar, Fílis presenteia-o com um cofre que contém os objectos consagrados à Grande Mãe Reia. Recomenda-lhe que o abra apenas no caso de perder toda a esperança de voltar a vê-la.

O tempo passa e, no dia aprazado, Fílis por nove vezes caminha em vão até ao porto na esperança de ver o amante / marido regressar. Desesperada, amaldiçoa-o e enforca-se.

Nesse mesmo dia, Demofonte, que se instalara em Chipre e aí casara, abre a caixa, donde sai um espectro que assusta o seu cavalo. Galopando desarvorado, Demofonte cai sobre a sua espada e é ferido mortalmente.

O caminho nove vezes feito por Fílis passou a chamar-se "Os Nove Caminhos".

No âmbito do mito cabe o enforcamento e metamorfose de Fílis em amendoeira sem folhas, existindo versões complementares: Demofonte torna à Trácia e beija a amendoeira, que se cobre de folhas. A folha passa a chamar-se (phylla), do nome de Fílis, perdendo a designação anterior, pétalas.

Noutra versão, a amendoeira plantada sobre a campa de Fílis perdia as folhas na efeméride da morte.

Motivo: exsecratio

Modo: forca

Temas: Atenas, desamor, Guerra de Tróia, magia, mito epónimo, corónimo, naufrágio, príncipe estrangeiro, simbologia dos números, Trácia, Tróia, viagens

Fontes:

BNP s.v. Phyllis $214 \mathrm{n}^{\circ} 1$

Grimal s.v. Phyllis 375; s.v. Démophon 121-122

RE s.v. Phyllis 1021-1025 no 3

Higino, Fábulas, 59 e 243

Ovídio, Ep. 2

[Van Hoof s.v. Phyllis: dolor, hanging, +, Hyg.Fab. 243,6]

\section{GANGES}

Ganges, o deus do rio Ganges, na Índia, é filho de Indo e da ninfa Caláuria. Certo dia, estando bêbado, une-se à sua mãe. Quando acorda, desesperado, atira-se ao rio, o qual, chamado até então Clíaro, passa a chamar-se Ganges.

Motivo: pudor 
Modo: afogamento

Temas: incesto, Índia, mito epónimo, hidrónimo, vinho

Fontes:

BNP s.v. Ganges 688 (nada diz)

Grimal s.v. Gangès 163

RE s.v. Ganges $703-707 \mathrm{n}^{\circ} 1$

[Van Hoof: não regista]

GLAUCE (ver Creúsa)

[Van Hoof: não regista]

\section{GLAUCO}

Glauco banha-se numa fonte que lhe confere a imortalidade. Como ninguém acredita no facto, atira-se ao mar. Noutra versão, fá-lo quando envelhece. A localização refere-se à cidade de Antédon, crético-micénica.

É metamorfoseado em deus marinho, híbrido, com numerosos cultos e variações na sua lenda. Anuncia a morte a quem o divisa.

Motivo: iactatio

Modo: afogamento

Temas: Creta, Micénicos, mito etiológico, metamorfose

Fontes:

BNP s.v. Glaucus $868-870$

Grimal s.v. Glaukos $166-167 \mathrm{n}^{\circ} 3$

RE s.v. Glaukos $1407-1423$ no 8

[Van Hoof s.v. Glaukos: furor, jumping, +, Athen. 7,297A]

\section{GORGE}

É filha de Megareu e casada com Corinto, o fundador da cidade de Corinto. Os filhos são massacrados e Gorge, desesperada, atira-se a um lago, que toma o nome de lago Gorgópis.

Motivo: dolor

Modo: afogamento

Temas: amor maternal, Corinto, mito epónimo, hidrónimo, perda de filhos

Fontes:

BNP (não regista entrada)

Grimal s.v. Gorgé $167-168 \mathrm{n}^{\circ} 2$

RE Gorge 1596-1597 n 3 (considera-a mãe de Megareu)

[Van Hoof: não regista]

\section{HÁLIA}

Hália é uma heroína de Rodes, irmã dos Telquines. Unida a Posídon, além de uma filha, Rodo, que dará o seu nome à ilha de Rodes, tem seis filhos. Afrodite enlouquece-os e eles tentam violar a mãe. Posídon, com o seu tridente, fá-los serem engolidos pela terra. Hália, desesperada, atira-se ao mar. 
Os habitantes de Rodes prestam-lhe culto de divindade marinha com o nome de Leucótea.

Motivo: dolor

Modo: afogamento

Temas: Afrodite, estupro, incesto, mito etiológico, Posídon, Rodes, vingança divina

Fontes:

BNP s.v. Halia $1109 \mathrm{n}^{\circ} 2$ ("The sons were driven insane by Afrodite as punishment for their hubris and raped their mother")

Grimal s.v. Halia $173 \mathrm{n}^{\circ} 1$

RE s.v. Halia $2232-2241 \mathrm{n}^{\circ} 2$

[Van Hoof s.v. Halia: pudor, jumping, +, Diod. 5,55,7]

\section{HALIÁCMON}

Um habitante de Tirinte, chamado Haliácmon, num acesso de loucura atira-se ao rio Carmanor, afogando-se. O rio toma o seu nome.

Motivo: furor

Modo: afogamento

Temas: mito epónimo, hidrónimo, Tirinte, Argólida

Fontes:

BNP s.v. Haliacmon 1109 (nada diz)

Grimal s.v. Haliacmon $173 \mathrm{n}^{\circ} 2$

RE s.v. Haliakmon 2241 (não menciona lenda)

[Van Hoof: não regista]

\section{HARPÁLICE 1 (ver Clímeno)}

Filha de Epicaste e do argivo Clímeno, de Argos. Seu pai abusa dela e assume a relação em público. Harpálice suicida-se.

Noutras versões é transformada em ave nocturna ou morta pelo pai. Ou mata o filho da relação incestuosa, servindo-o a seu pai.

Motivo: pudor

Modo: ?

Temas: antropofagia, Argos, filicídio, incesto, metamorfose

Fontes:

BNP s.v. Harpalyce 1148 n² (não explicita suicídio)

Grimal s.v. Harpalycé $174-175 \mathrm{n}^{\circ} 2$

RE Harpalyke 2401-4044 no 3

[Van Hoof s.v. Harpalyke: pudor, ?, +, Parthenios Er.Path.13]

\section{HARPÁLICE 2}

Rejeitada por Ífis ou Íficles, que ela amava, matou-se. Poderá ser mito etiológico de um canto lamentoso homónimo.

Motivo: dolor

Modo: ?

Temas: desamor, mito etiológico 
Fontes:

BNP s.v. Harpalyce $1148 \mathrm{n}^{\circ} 3$

Grimal s.v. Harpalycé 174-175 no 3 (não indica localização)

RE s.v. Harpalyce 2401-2044 no 2

[Van Hoof: não consta]

\section{HÉCUBA}

A troiana Hécuba, mulher de Príamo, personifica a desgraça devido à sua sorte atribulada. Entre numerosas lendas sobre esta personagem, existe uma que narra o que lhe aconteceu depois da queda de Tróia. Cativa, é enviada para a Grécia. Mas, no barco, transforma-se em cadela e atira-se borda fora para não servir Ulisses.

Mito etiológio de um escolho marinho chamado kynos sema 'túmulo da cadela'. Ligação ao culto de Hera na Ásia Menor.

Motivo: pudor

Modo: afogamento

Temas: Ásia, Guerra de Tróia, hibridismo, Mediterrâneo, metamorfose, misoginia, mito etiológico, Tróia

Fontes:

BNP s.v. Hecabe 34-35 ()

Grimal s.v. Hécube 177-178

RE s.v. Hekabe 2652-2662

Higino, Fábulas 111 (mudança em cadela); 243.1 (afogamento)

[Van Hoof s.v. Hekabe: desperata salus, jumping, +, Hyg.Fab. 111]

\section{HELENA}

Helena de Esparta é filha de Zeus e de Némesis, que, sob a forma de ovo, a entrega a Leda. Na versão de origem ródia, contada por Pausânias, depois da morte de Menelau e enquanto Orestes é perseguido pelo mundo fora pelas Erínias, os enteados de Helena, Nicóstrato e Megapentes, expulsam-na de Esparta. Helena refugia-se em Rodes, junto de Polixo, cujo marido, Tlepólemo havia morrido na Guerra de Tróia combatendo do lado grego. Polixo recebe-a aparentemente com amizade, mas na realidade arquitecta um plano de vingança. Veste as suas servas de Erínias e manda-as atormentar Helena durante o banho. Helena não aguenta a tortura e enforca-se.

Noutra versão, quando é ameaçada de enforcamento, Menelau salva-a, substituindo-a por uma escrava vestida como se fosse a própria Helena.

Pode tratar-se de etiologia do culto de Helena Dendrítis em Rodes (dendron 'árvore'), acaso um plátano, sob a qual nascia o helénio, antídoto contra a mordedura de serpentes.

Motivo: furor

Modo: forca

Temas: Ásia, beleza feminina, engano, Erínias, Esparta, Guerra de Tróia, Helena, mito etiológico, Rodes

Fontes:

BNP s.v. Helena 62-64 (não refere suicídio); s.v. Polyxo 539 n³ 3

Grimal s.v. Hélène 178-182 (suicídio); s.v. Polyxo 388 nº 2 (suicídio); s.v. Dendritis 122-123 (homicídio)

RE s.v. Helena $2823-2837$ n $^{\circ} 3$; s.v. Polyxo $1859-1864$ n $^{\circ} 5$

Eurípides, Helena, 298-305 (Helena projecta usar arma, não forca) 
Pausânias, 3.19.9-10 (Polixo mandou as suas servas vestidas de Erínias agarrar Helena durante o banho e enforcá-la numa árvore)

[Van Hoof s.v. Helena dolens: mala conscientia, weapons, -, Eur.Hel. 298+235]

[Van Hoof s.v. Helena in Troia: pudor, ?, -, Hom.Il. 3.173]

[Van Hoof s.v. Helena petita: fides, weapons, -, Eur.Hel. 839]

[Van Hoof s.v.: Helena repetita: desperata salus, poisons, -, Soph.Frg.Radt.178]

\section{HELÍADES}

Filhas e filhos de Hélio, da ilha de Rodes, e de Clímene, em número de sete. As irmãs, que tinham aparelhado os cavalos sem autorização paterna, choram tantas lágrimas à morte do irmão Faetonte que são transformadas em choupos.

Motivo: dolor

Modo: inedia

Temas: amor fraternal, metamorfose, paralelo com Cicno, perda de irmão, Rodes

Fontes:

BNP; s.v. Phaëton 905 n³; s.v Helliadae 68 (não refere)

Grimal s.v. Héliades $183 \mathrm{n}^{\circ}$ 1; s.v. Phaéton 363-364 nº 2

RE s.v. Heliadai 2849-2852 (vago); s.v. Phaethon 1508-1515 (explicita a versão)

Higino, Fábulas, 152, 154

[Van Hoof: não regista]

\section{HÉMON}

Noivo de Antígona e filho de Creonte, rei de Tebas (portanto Antígona e ele são primos). Mata-se com uma espada quando seu pai condena à morte a sua noiva e a encerra no túmulo dos Labdácidas.

Motivo: dolor

Modo: arma

Temas: amor e morte, conflito pai / filho, suicídio duplo, Tebas

Fontes:

BNP s.v. Haemon 1090-1091 n5; s.v. Antigone 745-746 n³

Grimal s.v. Haemon $172 \mathrm{n}^{\circ} 1$

RE s.v. Haimon 2217-2219 (não refere suicídio); s.v. Antigone 2401-2404 nº 3

Higino, Fábulas, 72

Sófocles, Antígona, 1175 (suicídio), 1231-1237 (espada)

[Van Hoof s.v. Haimon: desperata salus, weapons, +, Soph.Ant. 1234-1239]

\section{HÉRACLES 1 (ver Dejanira)}

Na versão que se encontra nas Traquínias de Sófocles e no Hércules sobre o Eta de Séneca, atormentado pelas dores causadas pelo veneno impregnado na túnica que Dejanira lhe oferecera, Héracles decide imolar-se numa pira que ele mesmo constrói sobre o monte Eta, pedindo aos seus escravos que lhe ateiem fogo, o que eles recusam fazer. É Neoptólemo quem satisfaz esse pedido, recebendo como recompensa o arco e as flechas do herói. Entretanto, Héracles é arrebatado para o céu no meio de sinais de tempestade.

O mito está relacionado com cultos do fogo realizados no cimo do monte Eta. 
Numa variante da lenda, quando a túnica se inflama, Hércules atira-se ao rio para apagar o fogo e morre afogado. O local passou a chamar-se Termópilas, do nome grego que quer dizer 'quente'.

Motivo: impatientia doloris

Modo: imolação pelo fogo

Temas: Eta, Héracles, magia, suicídio manu aliena, mito etiológico

Fontes:

BNP s.v. Heracles 156-163 (versão apresentada)

Grimal s.v. Héraclès 187-203 (3 versões, incluindo a do Hércules Furioso de Eurípides e o de Séneca)

RE s.v. Herakles 516-528 (etimologia do nome)

Eurípides, Hércules Furioso, 1247 (mortos os filhos, deseja de morrer, Teseu dissuade-o)

Higino, Fábulas, 36.3 (atira-se ao rio), 36.5 (morre no Eta)

Sófocles, Traquínias, 1253-1254 (imolação pelo fogo)

[Van Hoof: Herakles: impatientia doloris, fire, +, Soph.Trach. 1252 sqq.]

[Van Hoof: Herakles furens: dolor, fire, -, Eur.Her. 1246]

HÉRACLES 2 (ver Sileu, filha de)

$\mathrm{Na}$ Tessália, Héracles mata o prepotente e injusto Sileu e é acolhido em casa do irmão deste, Diceu 'O Justo', onde se apaixona pela filha do assassinado, a qual habitava com o tio e se chamaria Xenódice. Quando o amado tem de se ausentar por algum tempo, a jovem não consegue suportar a ausência e morre.

Regressado, Héracles quer atirar-se à pira fúnebre, mas é impedido.

Motivo: dolor

Modo: imolação pelo fogo

Temas: amor conjugal, Héracles, perda de mulher, suicídio frustrado,Tessália

Fontes:

BNP s.v. Herakles 156-163 (nada diz); s.v. Syleus 986 (não refere suicídio)

Grimal s.v. Sylée 432-433; s.v. Héraclès 187-203

RE s.v. Syleus 1039-1040

[Van Hoof: não regista]

\section{HERMÍONE}

Hermíone, filha de Helena e de Menelau, é casada com Neoptólemo e não tem filhos. Procura matar Andrómaca, a troiana que fora concubina do marido, e o filho desse concubinato, Molossos. Quando, nesse objectivo, se sente abandonada por seu pai Menelau e receia a reacção do marido, tenta suicidar-se enforcando-se (como já projectara várias vezes anteriormente), ou trespassando-se com uma espada, mas é impedida pela ama e pela criadagem (versão de Eurípides).

Motivo: conscientia

Modo: forca

Temas: Esparta, esterilidade feminina, Guerra de Tróia, suicídio frustrado

Fontes:

BNP s.v. Hermione (não refere suicídio)

Grimal s.v. Hermione 207-208 (não refere suicídio)

RE s.v. Hermione $841-844 \mathrm{n}^{\circ} 4$

Eurípides, Andrómaca, 802-827 
[Van Hoof s.v. Hermione: mala conscientia, hanging, -, Eur.Andr. 811]

\section{HERO}

Leandro e Hero, sacerdotisa de Afrodite, amam-se. Leandro vive em Abido e Hero mora do outro lado do Helesponto, em Sestos. Todas as noites Leandro atravessa o estreito a nado, guiado pela luz que Hero acende no cimo da torre de sua casa. Mas, numa noite de tempestade, a luz apaga-se e a escuridão não permite a Leandro reencontrar a costa. No dia seguinte, a maré leva o cadáver até à praia de Hero, que, não querendo sobreviver ao amado, se atira da torre.

Motivo: dolor

Modo: precipitação

Temas: Ásia, Europa, amor contrariado

Fontes:

BNP s.v. Hero 244

Grimal s.v. Léandre 255

RE s.v. 909-916 $\mathrm{n}^{\mathrm{o}} 1$

[Van Hoof s.v. Hero: desperata salus, jumping, +, Musaios 341]

HERSE (ver Cécrops, filhas de)

[Van Hoof s.v. Hero: desperata salus, jumping, +, Musaios 341]

\section{HIDASPES}

A filha Crisipa apaixona-se pelo pai Hidaspes e, através de um estratagema, com a ajuda da ama, consegue ter relações sexuais com ele. Ao descobrir o engano, Hidaspes empala a filha e mata-se atirando-se ao rio da região de Punjab, que recebe o seu nome.

Motivo: pudor

Modo: afogamento

Temas: ama, Ásia, engano, hidrónimo, incesto, Índia, mito epónimo

Fontes:

BNP s.v. Hydaspes 597-598 (não consta como mitónimo)

Grimal (não regista)

RE s.v Chrysippe 2498 n 3; s.v. Hydaspes 34-39 (não refere mitónimo)

[Van Hoof: não regista]

\section{HÍADES}

As Híades, duas a sete, conforme a versão, filhas de Atlas (ou de outrem) e de Plêione, irmãs de Hias e das Plêiades, teriam sido amas de Dioniso, com o nome de "Ninfas do Nisa".

Ao verem seu irmão Hias morto por uma fera, numa caçada, por desgosto, afogam-se. Zeus transforma-as em constelação (Híades).

O seu nome pode ainda relacionar-se com o termo grego para chover (hyein), pois anunciam a época das chuvas.

Motivo: dolor

Modo: afogamento 
Temas: amor fraternal, caça, metamorfose, mito etiológico, Nisa (Pártia, Ásia), perda de irmão, suicídio colectivo

Fontes:

BNP s.v. Hyades 590-591 ("forced to throw themselves into the sea"); s.v. Hyas 593 ("died of grief")

Grimal s.v. Hyades 215; s.v. Hyas 215 (suicídio); s.v. Pléiades 379 (assediadas pelo caçador Oríon, transformam-se em pombas e Zeus converte-as em constelação; ou por desgosto pela morte do pai; ou pela morte do irmão)

RE s.v. Hyaden $2615-2624$

Higino, Fábulas, 182, 192

Ovídio, Fastos, 5.159-182

[Van Hoof: não regista]

\section{HILÓNOME}

O centauro Cílaro morre no confronto entre os Centauros e os Lápitas, no casamento de Pirítoo, na Tessália. Sua mulher, a centaura Hilónome, não querendo sobreviver-lhe, mata-se com o mesmo dardo que o havia trespassado e morre enlaçada a ele.

Motivo: dolor

Modo: arma

Temas: amor conjugal, Centauros, perda do marido

Fontes:

BNP (não regista entrada)

Grimal s.v. Hylonomé 216; s.v. Cyllaros 110

RE s.v. Kyllaros 2454 (não regista esta lenda)

Ovídio, Met. 12.393-428 (419: iaculum 'dardo')

[Van Hoof: não regista]

\section{HÍMERO}

Lacedémon é filho de Taígete e de Zeus. Casa-se com Esparta, filha do rei Eurotas. Este morre sem filhos e lega-lhe o seu reino. Lacedémon dá o seu nome ao povo dos Lacedemónios e o da sua mulher a Esparta, a capital.

Deste casamento nascem filhos, entre eles Hímero. Este, depois de violar a sua irmã Ásina ou Cleódice, com os remorsos, atira-se ao rio Máraton, que toma o seu nome, mais tarde passando a Eurotas.

Motivo: conscientia

Modo: afogamento

Temas: Esparta, esturpo, hidrónimo, incesto, mito epónimo

Fontes:

BNP (não regista entrada); s. v. Lacedaemon 141-142 (nada diz)

Grimal s.v. Lacédaemon 247

RE s.v. Himeros $1635-1640 n^{\circ} 3$

[Van Hoof: não regista]

\section{HIPERBÓREOS}

O país dos Hiperbóreos, ligado ao culto de Apolo, é idealizado como um país da utopia, situado no extremo norte. As suas gentes têm uma vida longa e bem-aventurada. Quando, na velhice, entendem que a vida já foi aproveitada o suficiente, atiram-se do 
alto de uma falésia ao mar, com a cabeça coroada de flores, felizes por irem ao encontro da morte.

Motivo: taedium vitae

Modo: afogamento

Temas: Apolo, eutanásia, Hiperbóreos (Europa do Norte), velhice

Fontes:

BNP s.v. Hyperborei 630-631 (não refere)

Grimal s.v. Hyperboréens 217-218

RE s.v. Hyperboreer 258-279, especialmente 274-275

[Van Hoof: não regista]

HIPO (ver Escédaso, filhas de)

[Van Hoof s.v. Hippo: pudor, jumping, +, Val.Max. 6,1,ext.1]

\section{HIPODAMIA}

É filha de Enómao. Hipodamia vê o marido Pélops preferir Crisipo, fruto de um primeiro casamento com Axíoque, em detrimento dos dois filhos em comum, Atreu e Tiestes. Incita-os a assassinar o meio-irmão. Estes, perseguidos pela maldição paterna, fogem, levando Hipodamia, que se suicida.

Motivo: conscientia

Modo: ?

Temas: Atridas, noverca, Pélops, Pisa (Élide)

Fontes:

BNP s.v. Chrysippus 288 nº ; s.v. Hippodamia 364 nº $^{\circ}$ (matam o meio-irmão; descoberto o crime, fogem e Hipodamia suicida-se)

Grimal s.v. Hippodamie 211-212 (não fala em suicídio)

RE s.v. Hippodameia 1725-1730

Higino, Fábulas, 85, 243.3

Pausânias, 6.20.7 (nada diz)

[Van Hoof s.v. Hippodameia: desperata salus, ?, +, Hyg.Fab. 85]

\section{HIPÓNOO (ver Adrasto)}

Adrasto é rei de Argos. Dez anos após a primeira expedição dos Sete contra Tebas, empreende com os Epígonos (nome dado aos seis filhos dos outros heróis da primeira expedição), uma nova guerra contra Tebas. Tomam a cidade, aí estabelecendo como rei Tersandro, filho de Polinices. Mas Egialeu, ou Hipónoo segundo Higino, filho de Adrasto, é morto por Laódamas, filho de Etéocles. Adrasto morre de desgosto pela perda do filho. Segundo Higino, no seguimento de um oráculo de Apolo, ambos se suicidam pelo fogo.

Motivo: devotio

Modo: imolação pelo fogo

Temas: Argos, Atenas, oráculo de Apolo, perda do pai, Sete contra Tebas Fontes:

BNP s.v. Adrastus 154-155 n ${ }^{\circ}$; s.v. Aegialeus $189 \mathrm{n}^{\circ} 1$ (filho ou pai de Adrasto); s.v. Hipponous $n^{\circ} 2$ (seria antigo nome de Belerofonte) 
Grimal s.v. Adraste 13-14

RE s.v. Adrastos 411-416 n 1 (o velho Adrasto morre de desgosto pela perda do filho Egialeu na guerra)

Higino, Fábulas, 242.5 (imolação pelo fogo no seguimento de oráculo de Apolo)

Pausânias, 1.43 (morreu de velhice e de dor pela perda do filho Egialeu)

[Van Hoof s.v. Hipponoos: devotio, fire, +, Hyg.Fab. 2 (referência errada)]

HONETES (ver Semíramis)

Semíramis nasce na Síria, fruto dos amores da deusa Dérseto pelo jovem Caístro, com intervenção adversa de Afrodite. Abandonada em criança por sua mãe, é recolhida por pastores. Aí a encontra Honetes, inspector real ou sátrapa da Babilónia, que logo se apaixona e a desposa. Sendo muito bonita, corajosa e inteligente, Semíramis ajuda o exército real a ganhar uma guerra. Nino, o rei, apaixona-se por ela e propõe a Honetes dar-lhe a sua própria filha em troca. Honetes recusa e Nino ameaça arrancar-lhe os olhos. Desesperado, Honetes enforca-se.

Motivo: desperata salus

Modo: forca

Temas: Afrodite, amor conjugal, Babilónia, cegueira, cólera divina, exposição de crianças

Fontes:

BNP s.v. Onnes 133 (remete para Semiramis); s.v. Semiramis 237

Grimal s.v. Sémiramis 419

RE s.v. Onnes $482-482 \mathrm{n}^{\circ} 1$; s.v. Semiramis $1207-1208, \mathrm{n}^{\circ} 1$

[Van Hoof s.v. Onnes: dolor, hanging, +, Diod. 2,6,10]

\section{ÍDMON (ver Testor)}

Adivinho por vezes identificado com Testor, pai de Calcas. Sabe que morrerá na expedição dos Argonautas, mas parte, aceitando o destino.

Motivo: necessitas

Modo: ?

Temas: adivinhação, Argonautas, provocatio, destino

Fontes:

BNP s.v. Idmon $715-716$

Grimal s.v. Idmon 227

$\mathrm{RE}$ (não regista)

Higino, 14.11, 18

[Van Hoof: não regista]

\section{ÍFIS}

O jovem Ífis apaixona-se por Anaxárete, uma nobre de Chipre, descendente de Teucro, o fundador de Salamina de Chipre. Anaxárete é dura, de coração empedernido, insensível para com ele. Desesperado, enforca-se à porta da casa dela, que, da sua janela assiste, impávida, à passagem do féretro.

Como castigo, Afrodite transforma Anaxárete em estátua, exposta como Venus prospiciens 'A Vénus mirante'. 
Motivo: exsecratio

Modo: forca

Temas: Afrodite, castigo divino, Chipre, desamor, estatuária, mito etiológico

Fontes:

BNP s.v Iphis 930

Grimal sv. Anaxarétè 34; s.v. Iphis 236-237 I n 3

Ovídio, Met. 698-771 (lenda de Arcéofon e Arsínoe)

[Van Hoof s.v. Iphis: dolor, inedia,+, Eur.Hik. 1104-1108]

\section{ILÍONE}

Ilíone é filha mais velha de Príamo e de Hécuba, irmã de Polidoro. Casa-se com Polimnestor e têm um filho em comum, Deípilo. Cria-o juntamente com Polidoro, como irmãos. Mas Ilíone troca-lhes as identidades. Depois da queda de Tróia, Polimestor mata o seu próprio filho Deípilo, julgando ser Polidoro. Consultado o oráculo de Apolo para conhecer a sua identidade, Polidoro questiona Ilíone e instiga-a a matar Polimnestor. Ela cega-o e mata-o, e depois suicida-se.

Motivo: conscientia

Modo: ?

Temas: engano, Guerra de Tróia, oráculo, perda de filho, homicídio de marido, poder feminino, Tróia

Fontes:

BNP s.v. Ilione 726-727

Grimal s.v Ilioné 229; s.v. Deípilo e Polimestor; s.v. Déipyle 119; s. v. Polymestor 385 (nada explicita)

RE s.v. Ilione 1066

Higino, Fábulas, 109, 243.4, 254

[Van Hoof s.v. Ilione: dolor, ?, +, Hyg.Fab. 243,4]

\section{ÍNACO}

Ínaco é um deus-rio da Argólide. A sua filha Micena, epónimo da cidade de Micenas, é raptada por Zeus. Ínaco persegue o deus e Zeus envia-lhe uma Erínia, Tisífone, para o atormentar. Ínaco é de tal forma torturado que se lança ao rio até então chamado Haliácmon, e renomeado Ínaco.

Motivo: furor

Modo: afogamento

Temas: Argos, Erínias, hidrónimo, rapto, Zeus

Fontes:

BNP s.v.Inachus 759-760 n² (não explicita)

Grimal s.v. Inachos 230

RE s.v. Inachos 1218-1219 n 1 (não explicita)

[Van Hoof: não regista]

\section{INDO}

Indo é um jovem indiano de grande beleza que violenta a filha do rei Oxialces. Depois, para evitar o castigo, atira-se ao rio Mausolo, que passa a chamar-se Indo. 
Motivo: necessitas

Modo: afogamento

Temas: estupro, hidrónimo, Índia

Fontes:

BNP s.v. Indus 794 (não refere mitónimo)

Grimal s.v. Indos $230 \mathrm{n}^{\circ} 2$

RE s.v. Indos 1369-1373 (não refere o mitónimo)

[Van Hoof: não regista]

INO 1 (ou Leucótea, ver Ino 2)

Em primeiras núpcias, o rei beócio Atamante casa com Néfele e têm dois filhos, um rapaz, Frixo, e uma rapariga, Hele. Mais tarde, Atamante repudia Néfele e casa com Ino, a filha de Cadmo, conhecida também como Leucótea. Desta segunda relação nascem dois filhos, Learco e Melicertes, educados juntamente com a criança Dioniso, que haviam acolhido depois da morte de Sémele. Hera, irada com esta protecção ao bastardo do seu marido, provoca a loucura em ambos: Atamante mata Learco numa caçada; Ino lança Melicertes num caldeirão a ferver (noutra versão foi o próprio Atamante). Depois, atira-se ao mar com o corpo da criança, morrendo afogada.

A acção passa-se perto de Mégara. Ino é metamorfoseada em Nereide, com o nome de Leucótea, 'Deusa Branca', graças à intervenção das deusas marinhas (existe uma deusa marinha homónima). Em honra de Melicertes, heroizado como Palémon, teriam sido criados os Jogos Ístmicos.

Motivo: furor

Modo: afogamento

Temas: Beócia, caçada, Dioniso, engano, Hera, filicídio, Mégara, mito etiológico, vingança divina

Fontes:

BNP s.v. Ino $821 \mathrm{n}^{\circ} 1$; s.v. Melicertes 631

Grimal s.v. Athamas 56-57; s.v. Lélex 257-258; s.v. Leucothée 262; s.v. Mélicerte 287; s.v. Palameon 336-337

RE s.v. Leukothea 2293-2036 n ${ }^{\circ}$ 1; s.v. Melikertes 514-520

Higino, Fábulas, 2, 5, 238.1 (Ino afoga-se com Melicertes); 239.1 (mata Melicertes),

[Van Hoof: não regista]

INO 2 (ver Ino 1)

Ino é filha de Cadmo e Harmonia e segunda mulher de Atamante. Deste casamento nascem Learco e Melicertes. Movida pela inveja, Ino planeia matar os enteados Frixo e Hele, filhos do primeiro casamento de Atamante com Néfele. Para tal, convence as mulheres a torrarem o grão das sementes de trigo. Quando os homens as semeiam, nada cresce. Perante isto, Atamante envia mensageiros consultar o oráculo de Delfos mas Ino suborna-os para dizerem a Atamante que Apolo exige o sacrifício de Frixo, de forma a suster a infertilidade da terra.

No entanto, o mensageiro subornado por Ino apieda-se de Frixo e revela o complot a Atamante. Este ordena que Ino e Melicertes sejam sacrificados, em vez de Frixo. Mas, enquanto os conduzem ao altar, Ino, que havia sido ama de leite de Dioniso, é salva. O deus envolve-a numa nuvem que a torna invisível, o que permite a Ino fugir com Melicertes. Em seguida, Dioniso enlouquece Atamante, que mata Learco, seu filho mais 
novo. Ino atira-se com o corpo de Melicertes de um penhasco ao mar e passará a receber culto como Leucótea.

Uma outra versão introduz a figura de Temisto, a terceira mulher que Atamante tomara pensando que Ino estava morta, e de quem tem dois filhos, tantos como tivera com Ino. Mas, sabendo que Ino estava viva, Atamante acolhe-a no palácio secretamente. Ino torna-se confidente de Temisto, que projecta matar os filhos de Ino, combinando que esta os vestirá de negro, e aos dela de branco. Ino troca as cores e Temisto mata os seus próprios filhos. Enlouquecido, numa caçada, Atamante mata Learco, o filho mais velho que tivera com Ino. Ino precipita-se no mar com o mais novo, Melicertes.

Motivo: dolor

Modo: afogamento

Temas: amor maternal, Beócia, culto de fertilidade, Itália, oráculo de Delfos, perda de filho, mito etiológico, noverca, perturbação social, poder feminino, sacrifícios humanos

Fontes:

BNP s.v. Ino 821-822 no 1s.v. e 2; s.v. Melicertes 631; s.v. Athamas 229-230; Leucothea 451 (ora aparece confundida com Ino ora independente)

Grimal s.v. Athamas 56-57; s.v. Lélex 257-258; s.v. Leucothée 262; s.v. Mélicerte 287; s.v. Palameon 336-337

RE Leukothea 2293-2036 n 1; s.v. Melikertes 514 a 520

Lexikon s.v. Themisto 3041

Higino, Fábulas, 1, 2, 4 (Ino de Eurípides), 5, 224.5 (como Leucótea), 239 (instiga Temisto a matar os filhos), 243.1 (precipitou-se no mar com o filho Melicertes), 5 (instiga Temisto a matar os filhos),

[Van Hoof: dolor, jumping, +, Hyg.Fab. 2,5]

\section{ÍOLE}

Filha do rei Êurito, da Ecália, que a promete ao vencedor de um concurso de tiro ao arco, mas não cumpre o prometido quando o vencedor é Héracles. Despeitado, o herói ataca a cidade para fazer cumprir o acordo. Não querendo entregar-se a Héracles, a bela Íole atira-se do alto das muralhas. As suas vestes impedem-na sequer de se magoar.

Motivo: desperata salus

Modo: precipitação

Temas: desamor, Ecália, rapariga como prémio de jogos, suicídio frustrado, Héracles

Fontes:

BNP s.v. Iole 905 (não refere morte)

Grimal s.v. Iolé 232-233

RE s.v. Iole $1847-1848 \mathrm{n}^{\circ} 1$

[Van Hoof s.v. Iole: pudor, jumping, - , Plout.Mor. 308F]

\section{ISMENO}

Filho mais velho de Níobe e de Anfíon. É atingido pelas setas de Apolo. Moribundo, atira-se a um rio da Beócia, que passa a chamar-se Ismeno.

Motivo: impatientia doloris

Modo: afogamento

Temas: Apolo, Beócia, hidrónimo 
Fontes:

BNP s.v. Ismenus (não refere morte)

Grimal s.v. Isménos $239 \mathrm{n}^{\circ} 3$

RE s.v. Ismenos $2143-2145 \mathrm{n}^{\circ} 2$

Ovídio. Met. 6.224-229 (atingido por um dardo)

[Van Hoof: não regista]

\section{JASÃO (ver Alcímede)}

É filho de Éson e de Polimele ou Alcímede, herói da Tessália. Célebre pela chefia da expedição dos Argonautas e pelo casamento com a princesa de Iolco, Medeia.

Existem numerosas histórias a ele ligadas. Quanto à sua morte, correm várias versões, incluindo uma de suicídio.

Motivo: dolor

Modo: ?

Temas: Argonautas, Cólquida, Tessália

Fontes:

BNP s.v. Iason 682-685 (versões sobre suicídio: Diod. Sic. 4.55.1; enforcamento: Neophron fr.3 TGF; sangue de touro: Apollonius Sophista 156.18 (confusão com Éson?); imolação pelo fogo com a noiva: Hyg. Fab. 25.3)

Grimal s.v. Jason 242-243 (não refere suicídio)

RE s.v. Iason 759-782

Diodoro Sículo, 4.55 .1 (suicida-se por não conseguir suportar as desgraças)

Higino, Fábulas, 25.3 (não menciona morte)

[Van Hoof s.v. Iason: dolor, ?, +, Diod. 4,55,1]

\section{JOCASTA}

Filha de Meneceu e irmã de Creonte, casa com Laio, rei de Tebas. Depois da morte deste, casa com Édipo, que desvendara o enigma da Esfinge. Quando lhe é revelado que Édipo, de quem tem quatro filhos, é seu filho e de Laio, o primeiro marido, Jocasta enforca-se.

Motivo: pudor

Modo: forca

Temas: incesto, engano, Tebas, Édipo

Fontes:

BNP s.v. Iocaste, 886-887; s.v. Oedipus 43-48 (Hom. Od. 11.277-278)

Grimal s.v. Jocaste 243; s.v. Oedipe 323-325

RE s.v. Iokaste, $1841-1842$

Eurípides, Fenícias, 1577-1578 (depois de ver mortos Etéocles e Polinices, suicida-se de dor com brônzeo gládio)

Higino, Fábulas, 66 (nascimento e exposição de Édipo), 67, 243.7

Sófocles, Rei Édipo, 1263-1267

[Van Hoof s.v. Iokaste (Hom: Epikaste): pudor, hanging, +, Hom.Od. 11,278-280; cf. p.118]

\section{LAODAMIA}

Laodamia é filha de Acasto e mulher de Protesilau, da Tessália, o primeiro herói grego a morrer em Tróia. Recém-casada, nutre um amor intenso pelo seu marido. Sabendo da sua morte, Laodamia pede aos deuses que lho devolvam por três horas apenas. 
Protesilau também formula o mesmo desejo. Quando Protesilau tem que regressar ao Hades, Laodamia suicida-se nos seus braços.

Noutra versão, costumava abraçar-se a um boneco de cera. Quando o pai descobre e o atira para o fogo, Laodamia segue o boneco.

Motivo: dolor

Modo: imolação pelo fogo

Temas: amor conjugal, Hades, Guerra de Tróia, paralelo com Orfeu e Eurídice, perda do marido, Tessália, Tróia

Fontes:

BNP s.v. Laodameia $228 \mathrm{n}^{\circ} 2$ (Hyg. Fab. 103)

Grimal s.v. Laodamie $251 \mathrm{n}^{\circ} 2$

RE s.v. Laodameia $698 \mathrm{n}^{\circ} 2$

Higino, Fábulas, 103, 104 (usta est 'foi queimada'), 243

Ovídio, Ep. 13

Pausânias 4.2.5 (não diz nada)

[Van Hoof s.v. Laodameia: fides, fire, +, Hyg.Fab. 94,3ß]

\section{LEDA}

É filha do rei Etólio Téstio e mulher do rei espartano Tindareu. Assediada por Zeus, transforma-se em cisne mas Zeus também sofre a mesma metamorfose e fecunda-a. Leda entrega o ovo a Némesis e dele nasce Helena.

Segundo Eurípides, enforca-se, desgostosa com a má fama de Helena.

Motivo: pudor

Modo: forca

Temas: amor maternal, Esparta, Etólia, Helena, metamorfose, Zeus

Fontes:

BNP s.v Leda 345-346 (não refere morte)

Grimal s.v. Léda 255-256 (não fala em suicídio)

RE s.v. Leda 1116-1125

Eurípides, Helena, 201-202 (Helena afirma que Leda se enforcou com pena da filha)

[Van Hoof s.v. Leda: pudor, hanging, +, Eur.Hel. 200-201]

\section{LEUCATAS}

Perseguido sexualmente por Apolo, o jovem Leucatas precipita-se de uma falésia para o mar. Dá o seu nome à ilha local, Lêucade.

Motivo: desperata salus

Modo: afogamento

Temas: Apolo, assédio sexual, homo-erotismo, Lêucade, mito epónimo

Fontes:

BNP (não regista)

Grimal s.v. Leucatas 260

RE s.v. Leukatas 2259 (Templo de Apollon Leukatas como efígie de moeda); s.v. Leukates 2259-2260 no 3 (suicídio; paralelos: Boline, Kastalie)

[Van Hoof: não regista] 


\section{LEUCOCOMANTE}

Leucocomante, de Cnossos, não corresponde ao amor do jovem Prómaco, impondo-lhe duras tarefas que este cumpre sem obter correspondência. Numa dessas provas, o belo Prómaco recompensa um terceiro jovem. Cheio de ciúmes, Leucocamante suicida-se com uma espada.

Motivo: furor

Modo: espada

Temas: beleza masculina, Creta, desamor, homo-erotismo, servitium amoris

Fontes:

BNP (não consta)

Grimal s.v. Promachos 397

RE s.v. Promachos 642-646 nº 18

[Van Hoof: não regista]

\section{LEUCÓTEA (ver Ino 1 e 2)}

O culto da Deusa Branca (significado do seu nome), aparece ora associado a Ino ora independente. Sugere existência de atitudes anti-sociais e fálicas, e de ritos de iniciação e passagem para adultez. Pode também ser divindade marinha, como em Homero, onde já é identificada com Ino (ver Ino).

Depois da morte do filho Learco, Leucótea lança-se ao mar com o cadáver de Melicertes.

Motivo:dolor

Modo: afogamento

Temas: amor maternal, perda de filho, mito etiológico

Fontes

BNP s.v. Leucothea 451 (ora confundida com Ino ora independente)

Grimal s.v. Leucothée 262

RE s.v. Leukothea 2293-2306 n 1

[Van Hoof: não regista]

\section{LICURGO 1}

Lendário legislador de Esparta. Depois de criar e firmar as instituições sociais e políticas da cidade, parte para Delfos, fazendo o povo jurar que manteria a sua constituição até ao seu regresso. Em Delfos, o oráculo confirma que a constituição de Atenas é boa. Licurgo suicida-se.

Recebe culto em Esparta.

Motivo: devotio

Modo: inedia

Temas: Esparta, Delfos, herói fundador, oráculo

Fontes:

BNP s.v. Lycurgus 931-936 n 4 ("Legendary founder")

Grimal s.v. Lycurgue 268-270 n4 ("n'appartient pas à la legende, mais à l'histoire")

RE s.v. Lykurgos 2433-2466 n 7

Pausânias 3.16.6 (heroização)

Plutarco, Licurgo, 29 (devotio, inedia)

[Van Hoof s.v. Lykourgos: iactatio, inedia, +, Plout.Lyk. 29] 


\section{LICURGO 2}

É rei da Trácia e filho de Drias. Tenta obstaculizar o culto de Dioniso, quer impedindo a passagem do deus ou das Bacantes pela Trácia, quer cortando as videiras. Possuído por loucura induzida pelo deus, confunde uma videira com o seu filho Drias, matando-o à machadada e ferindo-se a si próprio, sem intenção. Gera-se uma carestia. Por ordem de Dioniso, é esquartejado.

Noutra variante, por ordem de Zeus é atingido por cegueira e encerrado numa caverna.

Existem versões muito divergentes: segundo Higino, tenta violar a mãe quando está ébrio e depois autopune-se arrancando as videiras; ou toma-se por videira e amputa um pé; ou uma Bacante transforma-o em videira para o asfixiar com seus braços.

Motivo: furor

Modo: arma

Temas: Bacantes, hybris, Dioniso, Trácia

Fontes:

BNP s.v. Lycurgus 931-936 (não regista)

Grimal s.v. Lycurgue 268 n² (não menciona suicídio mas homicídio por Dioniso)

RE s.v. Lykurgos 2433-2466 no 1

Apolodoro, Biblioteca, 3.4.5.1 .327 (não refere suicídio)

Higino, Fábulas, 242.2 (elenco dos suicidas, por loucura), 132 (loucura)

Sófocles, Antígona, 955-965

[Van Hoof s.v. Lykourgos Dryantis: furor, ?, +, Hyg.Fab. 242,2]

\section{LUCRÉCIA}

Esposa de Tarquínio Colatino. Na ausência do marido em Árdea, é violada por Sexto Tarquínio sob ameaça e coacção. Em seguida, manda chamar os familiares, que tentam dissuadi-la. Suicida-se com um punhal depois de os fazer jurar que expulsarão de Roma os reis etruscos.

Motivo: pudor

Modo: arma

Temas: estupro, poder feminino, Roma, Tarquínios, tiranicídio

Fontes:

Grimal (não regista entrada; a referida é mulher de Numa, p. 218b s.v. Numa Pompilius)

BNP s.v. Lucretia $857 \mathrm{n}^{\circ} 2$ (matrona romana, exemplo de pudicitia 'fidelidade')

RE s.v. Lucretius, Lucretia 1692-1695 nº 37

Tito Lívio, 1.57.1-60.3

[Van Hoof s.v. Lucretia: pudor, weapons, +, Liv. 1,58,11]

MACAREU (ver Cânace)

Cânace é filha de Éolo e de Enárete, de Lesbos. Segundo Ovídio (seguindo sem dúvida Eurípides), Cânace tem um filho do seu irmão Macareu. O bebé é escondido entre objectos sagrados e a ama tenta levá-lo para fora do palácio para o expor. Mas um grito do bebé revela-o a Éolo, que o atira aos cães e envia uma espada à sua filha Cânace, ordenando-lhe que se mate. Descoberta a paixão pela irmã, Macareu mata-se.

Motivo: pudor

Modo: arma

Temas: ama confidente, incesto, casamento entre irmãos, exposição de crianças, Lesbos 
Fontes:

BNP s.v. Maçar(eus) 52-53

Grimal s.v Macharée $272 \mathrm{n}^{\circ}$ 1; s.v. Canacé 78

RE s.v. Makar(eus) 617-622 nº 1

Ovídio, Ep.11

Higino, Fábulas, 242.2

[Van Hoof s.v. Makareus: pudor, ?, +, Eur.Aiolos]

\section{MACÁRIA}

É filha de Héracles e Dejanira. Depois da morte do pai, refugia-se com seus irmãos na corte de Ceíce, de Tráquin, e a seguir na de Teseu, em Atenas. Fogem à perseguição de Euristeu. Um oráculo anuncia que é necessário sacrificar uma jovem nobre para vencer Euristeu. Macária oferece-se à morte.

É-lhe consagrada uma fonte com o seu nome.

Motivo: devotio

Modo: arma

Temas: Atenas, Héracles, mito epónimo, oráculo, sacrifício feminino, Tráquin

Fontes:

BNP s.v. Macaria $53 \mathrm{n}^{\circ} 1$

Grimal s.v. Macaria 272; Héraclides 203-204

RE s.v. Makaria 622-625 n 1

[Van Hoof s.v. Makaria: devotio, ?, +, Eur.Herakleid. 530 ss.]

\section{MÁRATO}

Márato combate ao lado de Equedemo na expedição dos Dioscuros contra a Ática. Um oráculo exige uma vítima humana para assegurar a vitória dos assediantes. Márato sacrifica-se voluntariamente. O seu nome é dado ao demo de Maratona.

Motivo: devotio

Modo: arma

Temas: Atenas, provocatio, mito epónimo, suicídio manu aliena

Fontes:

BNP (não regista)

Grimal s.v. Marathos 276

RE s.v. Marathon 1426-1430 nº

Plutarco, Teseu, 32 (Márato e Equedemo oferecem-se no campo de batalha)

Pausânias 1.15.3 (pintura do herói Marathon, que deu nome à planície), 32.4 (dá o nome ao demo)

[Van Hoof: não consta]

\section{MARPESSA}

Filha de Éveno da Etólia e de Demonice. É raptada por Apolo quando está noiva de Idas. Na luta que se segue, Idas desarma Apolo. Zeus intervém, deixando Marpessa escolher entre os dois pretendentes. Ela fica com o mortal, receando ser abandonada na velhice pelo deus. Noutra lenda, Idas ganhou Marpessa como prémio em corrida de carro de cavalos.

Pausânias diz que Marpessa se degolou à morte do marido. 
Motivo: dolor

Modo: arma

Temas: amor conjugal, Apolo, humano vence um deus, paralelo com lenda de Enómao e Hipodamia, perda de marido, prémio de jogos, Zeus

Fontes:

BNP s.v. Marpessa $385 \mathrm{n}^{\circ} 1$ (não refere a morte)

Grimal s.v. Marpessa 276; s.v. Coronis 100 n $^{\circ}$ 1; s.v. Idas 226

RE s.v. Marpessa 1916-1918 (não refere suicídio)

Pausânias, 4.2.7

[Van Hoof: não regista]

\section{MEDEIA}

É filha de Eetes, rei da Cólquida, e neta de Hélio. É figura central do mito tessálico dos Argonautas, liderados por Jasão. Numa das versões sobre a sua vida após o abandono de Jasão, aparece como mãe de Medo e epónima dos Medos (ver Medo).

Apolónio de Rodes apresenta uma versão de suicídio.

Motivo: ?

Modo: ?

Temas: Argonautas, Cólquida, colonização iónica, Tessália, mito epónimo

Fontes:

BNP s.v. Medea 546-549 (não refere suicídio)

Grimal s.v. Médée 278-279 (não refere suicídio)

RE s.v. Medeia 29-64

Higino, Fábulas, 21, 25, 26, 27 (não refere suicídio)

Pausânias, 2.3. 6-11 (refere matricídio, não morte)

[Van Hoof s.v. Medeia: dolor, hanging, -, Apoll.Rhod. 3,789]

\section{MEDO}

É filho do rei persa Artaxerxes e de Medeia (ou de Egeu e Medeia). Viola Roxane, filha de Córdias. Com medo do castigo, Medo atira-se ao rio Xarandas, que recebe o nome de Medo (mais tarde será o Eufrates). É herói epónimo dos Medos e da Média (Mesopotâmia).

Motivo: conscientia

Modo: afogamento

Temas: Cólquida, estupro, Medeia, Medo-Persas, mito epónimo, hidrónimo

Fontes:

BNP (não consta)

Grimal s.v. Rhoxane 410; s.v. Médos 280 (não refere morte)

RE; s.v. Medeia 29-64 (esp. 47); s.v. Medeios 64-65 (nada refere); Medos 113 nº 1 (não refere morte)

Diodoro Sículo, 4.55.4-56.2

Higino, Fábulas, 27

Pausânias, 2.3.7 (mito epónimo)

[Van Hoof: não regista] 


\section{MELEAGRO, IRMÃS de}

Meleagro é filho de Ares ou Eneu, rei dos etólios de Cálidon. Quando morre, as irmãs choram-no até ficarem metamorfoseadas nas aves homónimas.

Motivo: dolor

Modo: inedia

Temas: mito epónimo, Etólia, metamorfose, amor fraternal,

Fontes:

Higino, Fábulas, 174.6-7

[Van Hoof: não consta]

\section{MELES 1 (ver Timágoras 1)}

O jovem ateniense Meles (ou Melito) desprezava o amor do meteco Timágoras, impondo-lhe toda a espécie de duras provas. Acaba por o desafiar a atirar-se do alto dos rochedos da Acrópole. Timágoras assim faz. Desesperado, Meles também se atira. Em consequência, é erigido um altar a Ânteros ('Amor Correspondido'), onde os estrangeiros domiciliados em Atenas celebravam um culto que lhes era próprio.

Motivo: furor

Modo: precipitação

Temas: Atenas, desamor, duplo suicídio, homo-erotismo, metecos, mito etiológico, servitium amoris

Fontes:

BNP s.v. Meles 628

Grimal s.v. Mélès 286

RE Meles 491-492 $\mathrm{n}^{\circ} 1$ (ambas as versões)

Pausânias, 1.30.1 (Timágoras matou-se por remorso, metanoia)

[Van Hoof: não consta]

MELES 2 (ver Meles 1; ver Timágoras 1 e 2)

Existe uma história similar à de Meles 1, de Eliano, mas entre dois aristocratas atenienses, onde os nomes são iguais mas a relação amorosa é inversa. $\mathrm{O}$ amado Meles ou Melito executa todas as exigências de Timágoras. Quando lhe traz aves raríssimas e não o demove, Meles atira-se do alto de um rochedo. É seguido pelo seu amante, Timágoras.

Motivo: desperata salus

Modo: precipitação

Temas: Atenas, desamor, homo-erotismo, servitium amoris, suicídio duplo

Fontes:

BNP s.v. Meles 628

Grimal s.v. Mélès 286

RE Meles 491-492 $\mathrm{n}^{\circ} 1$ (ambas as versões)

Pausânias, 1.30.1 (Timágoras matou-se por remorso)

[Van Hoof s.v. Meles: desperata salus, jumping, +, Paus. 1,30,1] 


\section{MELIBEIA}

Melibeia e Aléxis amam-se e planeiam casar-se. Mas os pais da rapariga haviam-na prometido a outro, o que leva Aléxis a exilar-se. No dia do casamento imposto, a jovem precipita-se do telhado. Saindo ilesa, de imediato corre para o porto e faz-se ao largo num barco cujas velas se desfraldam sozinhas. Desembarca justamente no sítio onde Aléxis reúne amigos para um banquete. Casam e oferecem um santuário a Ártemis, em Éfeso, com as invocações de Autómata (como o barco que parte automaticamente) e Epidieta (que chega mesmo no início do banquete).

Motivo: desperata salus

Modo: precipitação

Temas: amor contrariado, Ártemis, Éfeso, final feliz, mito etiológico, navegação, suicídio frustrado

Fontes:

BNP (não regista esta entrada)

Grimal s.v. Méliboea $286 \mathrm{n}^{\circ} 3$

RE s.v. Meliboia 509-514 n ${ }^{\circ} 1$

[Van Hoof: não consta]

\section{MELISSO}

Melisso foge de Argos para Corinto por causa do tirano Fídon. O seu filho Actéon morre durante a tentativa de rapto pelo Heraclida Árquias, cuja paixão fora acicatada pelo vinho. Melisso lança maldições sobre Árquias perante os cidadãos de Corinto. Mas ninguém se revolta. Então Melisso aproveita os Jogos Ístmicos para se atirar do alto do Templo de Posídon, invectivando e lançando maldições sobre o assassino. A cidade é assolada por uma peste. Como consequência, Árquias exila-se e funda Siracusa.

Motivo: exsecratio

Modo: precipitação

Temas: amor paternal, Argos, colonização, Corinto, homo-erotismo, iactatio, Jogos Ístmicos, vinho

Fontes:

BNP (não regista esta entrada)

Grimal s.v. Mélissos 287

RE Melisso 529-532 n'1

Plutarco, Obras Morais, 773a

Diodoro Sículo 8.10 (só refere a morte de Actéon)

[Van Hoof s.v. Melissos: exsecratio, jumping, +, Plout.Mor. 773A]

\section{MELO (ver Pélia)}

Melo é originário de Delos e vai viver para Chipre, na corte do rei Cíniras. Torna-se o amigo dilecto de Adónis e casa-se com uma jovem da família real, Pélia, filha de Peleu. Adónis morre e Melo, desesperado, enforca-se numa árvore que fica com o nome de melos 'macieira'. Pélia enforca-se na mesma árvore.

Afrodite, que amava Adónis e tinha sob a sua protecção o filho de Melo e Pélia, condóise e transforma Melo no fruto homónimo, a maçã, e Pélia, sua mulher, em pomba, ave sagrada da deusa.

Depois de crescer sob a protecção da deusa, o filho de ambos, Melo, funda a cidade de Melo (conhecida como Milo) e ensina a trabalhar a lã (melon 'ovino'). 
Motivo: dolor

Modo: forca

Temas: Afrodite, amizade, Chipre, colonização, Delos, mito etiológico, mito epónimo, perda de amigo, suicídio duplo

Fontes:

BNP (não regista)

Grimal s.v. Mélos 287-288

$\mathrm{RE}$ (não consta)

[Van Hoof: não regista]

\section{MENECEU}

Filho do rei Creonte e pai de Jocasta. De acordo com o adivinho Tirésias, terá que ser sacrificado para que Tebas alcance a vitória na expedição de 'Os Sete contra Tebas'.

$\mathrm{Na}$ versão da tragédia As Fenícias, de Eurípides, Creonte procura afastar o filho. Quando este descobre o motivo, consegue iludir o próprio pai e oferece-se em sacrifício voluntário: degola-se no cimo de um torreão e cai do alto das muralhas para a cova de um dragão.

Sobre o túmulo de Meneceu nasce uma romãzeira.

Motivo: devotio

Modo: arma

Temas: dragão, morrer pela pátria, Sete contra Tebas, Tebas

Fontes:

BNP s.v. Menoecus 696 n²

Grimal s.v. Ménoecée $291 \mathrm{n}^{\circ} 2$

RE s.v. Menoikeus $918 \mathrm{n}^{\circ} 2$

Eurípides, Fenícias, 991-1018, 1090-1092

Higino, Fábulas, 67.6 (morreu pela pátria); 68.4 (precipitação); 242.3 (precipitação)

Pausânias, 9.25.1 (sobre a sua campa, uma romãzeira)

[Van Hoof s.v. Menoikeus: devotio, weapons, +, Eur.Phoin. 331]

MERA (ver Entória, Erígone, Icário)

Mera é o nome do cão (ou cadela) do herói Icário, introdutor da vinha na Ática e despedaçado pelos camponeses que, tendo-se embriagado, julgam ter sido envenenados. É Mera quem conduz Erígone ao túmulo de seu pai. Depois do suicídio de Erígone, o canídeo fica sobre o túmulo e morre de desespero ou atira-se à nascente Onigro.

Dioniso transforma este cão fiel numa constelação: o Cão.

Motivo: dolor

Modo: inedia

Temas: astronomia, Ática, Dioniso, sentimentos dos animais, simbologia animal, mito etiológico, mito epónimo.

Fontes:

BNP s.v. Maera $122 \mathrm{n}^{0} 3$ (não indica modo)

Grimal s.v. Maera $274 \mathrm{n}^{\circ} 3$ (deixa-se morrer ou atira-se a uma nascente)

RE s.v. Maira 604-606 n 4 (morre de saudades, sob a campa de Erígone)

Higino, Fábulas, 130.5

[Van Hoof s.v. Erigones canis: dolor, jumping, +, Amp. 2,6] 


\section{MÉROPS}

Mérops é rei de Cós. Sua mulher, a Ninfa Etémea, quando se casa com ele, deixa de pertencer ao séquito da deusa virgem Ártemis. A deusa vinga-se trespassando-a com flechas. Etémea não morre porque Perséfone leva-a viva para os Infernos. Sem a mulher, Mérops fica desesperado e decide suicidar-se. Mas Hera tem pena dele. Libertao do sofrimento, transforma-o em águia e coloca-o entre os astros.

Motivo: dolor

Modo: inedia

Temas: Ártemis, astronomia, Cós, metamorfose, perda de esposa, protecção divina, Perséfone, suicídio frustrado, vingança divina, mito epónimo

Fontes:

BNP s.v. Merops $719 \mathrm{n}^{\circ} 1$ ("from grief and longing for his spouse Echemeia, who had been sent to Hades, he is transformed into an eagle by Hera and finally catasterized")

Grimal s.v. Éthéméa 149 (quer suicidar-se)

RE s.v. $1065-1067 \mathrm{n}^{\circ} 1$ (quer suicidar-se)

[Van Hoof: não consta]

\section{MIENO}

É filho de Telestor e de Alfesibeia. A madrasta difama-o junto de seu pai, acusando-o de paixão incestuosa por ela. Mieno retira-se para a montanha. Perseguido pelo pai, atira-se do alto de uma falésia.

A montanha local recebe o seu nome.

Motivo: desperata salus

Modo: precipitação

Temas: incesto, noverca, mito epónimo, orónimo, paralelo com Fedra / Hipólito, theriodes bios

Fontes:

BNP (não regista)

Grimal s.v. Myènos 304

RE (não consta)

[Van Hoof: não regista]

\section{MIRRA}

Na versão de Ovídio, Mirra ou Esmirna, filha de Cíniras, rei de Chipre, é pretendida por jovens de toda a Ásia, mas apaixona-se por seu pai. Decide enforcar-se mas é descoberta pela ama quando já tem o laço à volta do pescoço. A ama arquitecta um engano para levar Mirra ao leito de seu pai, quando este está ébrio e a mulher ausente. Uma noite Cíniras reconhece na amante a sua própria filha e sente uma dor imensa. Vai matá-la com a espada, mas ela foge e leva uma vida errante por toda a Arábia, até se cansar. Pede então às divindades uma metamorfose, e é ouvida. Transforma-se na árvore homónima. Da relação com Cíniras nasce Adónis.

Noutra versão, Mirra, ou Esmirna, é filha do rei Tiante da Síria e vítima de Afrodite. Apaixona-se pelo seu próprio pai e com ele pratica incesto durante 12 noites, com ajuda da ama. Quando ele descobre o embuste, ameaça-a de morte. Mirra foge e, a seu pedido, é transformada na árvore da mirra, donde virá a nascer Adónis.

Motivo: taedium vitae 
Modo: inedia

Temas: Adónis, Afrodite, ama, Arábia, Síria, Chipre, engano, metamorfose, mito epónimo, suicídio frustrado

Fontes:

BNP s.v. Myrrha 420; (não tem entrada para Smyrna)

Grimal s.v. Myrrha 306; s.v. Smyrna 427; s.v. Adonis 11-12 (refere amores pecaminosos, tentativa de enforcamento, metamorfose)

RE s.v. Myrrha $1134 \mathrm{n}^{\circ} 1$ remete para Smyrna; s.v. Smyrna oder Myrrha 727-765 no2 (duas versões: filha de Tiante; filha de Cíniras)

Higino, Fábulas, 58 (como Ovídio, filha de Cíniras e de Cêncreis, da Assíria), 164, 242 (Esmirna, filha de Cíniras)

Ovídio, Met. 10.298-502 (v.517-518)

[Van Hoof s.v. Myrrha (Smyrna): pudor, hanging, -, Ov.Met. 10,378]

\section{MOLPADIA e PÁRTENO}

São filhas de Estáfilo e de Crisótemis. Seu pai encarrega-as de ficar de guarda ao vinho, acabado de descobrir. Mas as jovens adormecem. Os porcos invadem a adega e quebram as ânforas. Quando Molpadia e Párteno (ou Reo) acordam, com medo do pai, atiram-se ao mar do alto de uma falésia.

Compadecido, Apolo salva-as e leva-as para a cidade de Cástabo, do Quersoneso, onde recebem culto.

Motivo: desperata salus

Modo: afogamento

Temas: Apolo, Ásia, mito etiológico, suicídio colectivo, suicídio frustrado

Fontes:

BNP s.v. Molpadia 132; s.v. Parthenos 571 (não regista esta entrada)

Grimal s.v. Parthénos 349

RE s.v. Molpadia no 1; s.v. Parthenos 1936-1968 n³ (p.1967; eventual relação com nº 1)

[Van Hoof s.v. Molpadia et Parthenos: pudor, jumping, -, Diod. 5,62,3]

MÓLPIA (ver Escédaso, filhas de)

[Van Hoof: não regista]

\section{MÓLPIS}

Mólpis é um nobre da Élide. Durante uma fome que assola o país, sacrifica-se voluntariamente sob as ordens de um oráculo, para acalmar a fúria dos deuses. São-lhe atribuídas honras divinas, com uma estátua no templo de Zeus Ombrios, 'da Chuva'.

A lenda seria mito etiológico.

Motivo: devotio

Modo: arma

Temas: Élide, mito etiológico, oráculo, Zeus

Fontes:

BNP (não regista entrada)

Grimal s.v. Molpis 301

RE Molpis 27-28 $n^{\circ} 1$

[Van Hoof: não regista] 
NARCISO 1 (ver Eco)

Existem diferentes versões da lenda. A mais conhecida é a versão de Ovídio nas Metamorfoses. Narciso é filho do deus Cefísio, rio da Beócia, e da Ninfa Liríope. Quando nasce, o adivinho Tirésias vaticina que a criança "viverá até velho, se não se olhar". De grande beleza, Narciso é alvo da paixão de muitos homens, mulheres e ninfas, mas não corresponde nunca a esses sentimentos.

A ninfa Eco, quando se apaixona por ele, desespera e retira-se na solidão, emagrecendo até ser apenas uma voz que geme. Solidárias com Eco, as outras mulheres desprezadas por Narciso clamam aos deuses por vingança. E Némesis aplica o golpe de misericórdia: num dia de grande calor, depois da caça, provoca em Narciso o desejo de se debruçar sobre uma fonte para matar a sede. Quando vê a beleza do seu rosto, Narciso não mais sai do sítio, nas margens do rio Estige, até morrer por inedia.

No local onde morre, nasce uma flor, à qual será dado o seu nome.

Motivo: furor

Modo: inedia

Motivos: Beócia, castigo da beleza, homo-erotismo, mito epónimo, misoginia, narcisismo, Némesis, paralelo com Hipólito, rito de passagem, theriodes bios

Fontes:

BNP s.v. 506-507 Narcissus (corrobora esta versão)

Grimal s.v. Narcisse 308-309; s.v. Echo 132-133

RE s.v. Echo 1926-1930; s.v. Narkissos 1721-1733 n¹

Higino, Fábulas, 261.2

Ovídio, Metamorfoses, 3.402-510

Pausânias, 9.31.7-9 (suicídio fica subentendido)

[Van Hoof: não regista]

NARCISO 2 (ver Amínias)

$\mathrm{Na}$ versão beótica, é natural de Téspias, junto do monte Hélicon. O belo Narciso não corresponde ao amor do jovem Amínias. Chega mesmo a enviar-lhe uma espada com que este se suicida, lançando imprecações sobre o amado.

Narciso, ao debruçar-se sobre uma fonte para matar a sede, apaixona-se pela sua própria beleza e acaba por se suicidar. O local do suicídio fica manchado com o seu sangue, aí nascendo uma flor, com o seu nome.

Motivo: furor

Modo: arma

Temas: castigo da beleza, desamor, espada enviada (paralelos), exsecratio, homoerotismo, mito epónimo, narcisismo, recusa do amor

Fontes:

BNP s.v. Narcissus 506-507

Grimal s.v. Narcisse 308-309

RE s.v. Ameinias $1818 \mathrm{n}^{\circ}$ 2; s.v. Narkissos 1721-1733 $\mathrm{n}^{\circ} 1$

[Van Hoof s.v Narkissos: dolor, weapons, +, Konon, frg. 24 (FGrH 1.197)]

\section{NÁUPLIO}

É filho de Posídon e Amimone, pai de Palamedes e grande navegador. Na sua tentativa de lançar Penélope nos braços dos pretendentes, como vingança por os gregos terem 
lapidado Palamedes, é enganado por Anticleia, mãe de Ulisses. Esta anuncia-lhe a morte de um dos seus filhos. Na sua dor, Náuplio atira-se ao mar e afoga-se.

Provavelmente identifica-se com o herói epónimo de Náuplia, perto de Argos.

Motivo: dolor

Modo: afogamento

Temas: amor paternal, Argos, Guerra de Tróia, mito epónimo, perda de filho, Náuplia, navegação, Penélope

Fontes:

BNP s.v. Nauplius $550 \mathrm{n}^{\circ} 1$ (não menciona suicídio)

Grimal s.v. Nauplios 309 n 2 (suicídio)

RE s.v. Nauplios 2004-2008

Apolodoro, Biblioteca, 2.1.5 (não especifica suicídio)

Higino, Fábulas,116 (não refere o suicídio)

[Van Hoo: não consta]

\section{NEERA}

É filha de Autólico, pai de Ulisses, de Ítaca. Suicida-se à morte do filho Hipótoo.

Motivo: dolor

Modo: ?

Temas: amor maternal, Ítaca, perda de filho

Fontes:

BNP s.v. Neaera 577 (nenhum dos 6 registos refere suicídio; remete para outras entradas)

Grimal (não regista entrada)

RE (não refere)

Higino, Fábulas, 243.4

[Van Hoof s.v. Neaira: dolor, ?, +, Hyg.Fab. 243,4]

\section{NICTEU}

O tebano Nicteu, filho de Hirieu e de Clónia, é pai de Antíope. Segundo outras versões, Antíope é filha do deus-rio Asopo. Sendo muito bela, Zeus une-se a ela sob a forma de um sátiro. Antíope fica grávida de gémeos. Temendo a cólera do pai, foge de casa e refugia-se na corte de Epopeu em Sícion, antes do nascimento dos gémeos, Anfíon e Zeto.

Noutra versão, Nicteu envia a filha a seu irmã Lico, para ser castigada.

Desesperado com a fuga da filha, Nicteu ataca Sícion, onde morre, ou suicida-se, confiando a vingança e o castigo de Antíope ao irmão Lico.

Motivo: pudor

Modo: ?

Temas: Mégara, Tebas, vingança, Zeus

Fontes:

BNP s.v. Nycteus $922-923$

Grimal s.v. Antiope 39 (refere o suicídio); s.v. Nyctée 319 (menciona o suicídio)

RE s.v. Nykteus $1511-1515 \mathrm{n}^{\circ} 2$

Apolodoro, Biblioteca, 3.5.5 (suicídio: 'In a fit of despondency Nycteus killed himself', trad. Loeb)

Pausânias, 2.6.1-3

[Van Hoof: não regista] 
NíOBE (ver Assáon)

Níobe é filha de Assáon, que a casa com o assírio Filoto. Mas este morre durante uma caçada e Assáon apaixona-se pela sua própria filha. Níobe não se entrega e Assáon vinga-se de forma terrífica: reúne os seus vinte netos, filhos de Níobe, para uma festa e incendeia o palácio. Todos morrem queimados. Assáon, com remorsos, mata-se. Níobe atira-se do alto de uma falésia, sendo transformada em pedra.

Motivo: dolor

Modo: precipitação

Temas: amor maternal, assédio de pai, Assíria, perda de filhos

Fontes:

BNP s.v. Niobe 770-772 (Parténio)

Grimal s.v. Assaon 55; s.v Niobé 317 n²

RE s.v. Niobe 644-706 nº (esp. p.665-666); s.v. Assaon 1741 (Reue 'arrependimento')

Higino, Fábulas, 9

Ovídio, Met. 6.146-312

Pausânias, 1.21.3 (estátua de Níobe em lágrimas)

Parténio, 33 (lenda Lídia: atira-se de penhasco ao ser assediada)

[Van Hoof s.v. Niobe: pudor, jumping, +, Parthenios Er.Path. 33,3; cf. p.118]

\section{NIREU}

Nireu, de Cátana, por desgosto de amor, atira-se ao mar de uma falésia da ilha de Lêucade. É salvo ao cair numa rede de pescadores.

Motivo: dolor

Modo: afogamento

Temas: Atena, desamor, Lêucade, rede de pesca (paralelos), suicídio frustrado

Fontes:

BNP s.v. Nireus $775 n^{\circ} 3$

Grimal s.v. Nirée $317-318 \mathrm{n}^{\circ} 2$

RE s.v. Nireus $708-709 \mathrm{n}^{\circ} 3$

[Van Hoof: não regista]

\section{NISO 1 (ver Cila)}

É filho de Pandíon, rei de Mégara. Depois de perder a madeixa de cabelos que lhe dava poderes, cortada à traição pela filha Cila, mata-se.

É transformado em águia sempre em perseguição da filha, por sua vez metamorfoseada no peixe homónimo.

Motivo: pudor

Modo: ?

Temas: cabelo mágico, Mégara, mito etiológico

Fontes:

BNP s.v. Nisus $779 \mathrm{n}^{\circ} 1$

Grimal s.v. Nisos $318 n^{\circ} 1$

RE s.v. Nisos $759-760 n^{\circ} 1$

Higino, Fábulas, 242.3 (filho de Marte)

[Van Hoof s.v. Nisos: desperata salus, ?, +, Hyg.Fab. 242,3] 
NISO 2 (companheiro de Euríalo)

$\mathrm{Na}$ Eneida de Virgílio, os jovens troianos Niso e o belo Euríalo, que haviam chegado a Itália na companhia de Eneias, saem em expedição nocturna para ir ao encontro deste, mas são descobertos. Euríalo é morto. Niso, em vez de fugir e se salvar, avança contra o inimigo. É morto sobre o corpo do seu amigo.

Motivo: dolor

Modo: arma

Temas: camaradagem de armas, expedição nocturna, provocatio, Guerra de Tróia, homo-erotismo, Itália, suicídio manu aliena, Tróia

Fontes:

BNP s.v. Nisus $779 \mathrm{n}^{\circ} 2$

Grimal s.v. Nisos $318 \mathrm{n}^{\circ} 2$

RE s.v. Nisos $759-760 \mathrm{n}^{\circ} 3$

Virgílio, Eneida, 9.176-459 (em esp. 399-401 e 444-445)

[Van Hoof: não regista]

\section{OCNA}

Ocna, da Beócia, ama seu tio Eunosto, mas é um amor não correspondido. Sentindo-se desprezada, Ocna calunia-o perante os seus irmãos, Équemo, Leone e Búcolo: Eunosto teria tentado violá-la. Os irmãos reagem e matam Eunosto. Consumida pelos remorsos, Ocna confessa a verdade. Os irmãos fogem, ameaçados pelo pai de Eunosto, e ela enforca-se ou atira-se de um penedo.

Motivo: conscientia

Modo: precipitação

Temas: Beócia, desamor, intriga feminina, misoginia, paralelo com Fedra

Fontes:

BNP (não regista entrada)

Grimal s.v. Boucolos 67 (enforcando-se)

RE s.v. Bukolos 1017-1019 nº 4; s.v. Ochne 1768 (atira-se de um penedo)

Plutarco, Obras Morais, 300f (precipitou-se)

[Van Hoof s.v. Ochne: mala conscientia, jumping, +, Plout.Mor. 300F]

\section{ORESTES}

É filho de Agamémnon e de Clitemnestra, irmão de Electra. Na lenda que situa o seu julgamento por matricídio na Argólide, Orestes é condenado à morte, sendo-lhe dada a escolha do meio. É a versão de Eurípides, Orestes.

A lenda pode ter uma componente de ritual de iniciação ou de transição.

Motivo: necessitas

Modo: arma

Temas: Argos, deus ex machina, Guerra de Tróia, matricídio, rito de transição, sentença de morte, vingança pelo assassinato do pai

Fontes:

BNP s.v. Orestes 198 (não refere suicídio)

Grimal s.v. Oreste 329-331

RE s.v. Orestes 966-1014 (esp.986-991: não fala em suicídio) 
Eurípides, Orestes, 947 ss. (mensageiro sugere-lhe espada ou forca; 1035-1084 Orestes pensa em espada ou forca; Electra decide usar a espada)

[Van Hoof: Orestes 1: mala conscientia, ?, -, Eur.Or. 415]

[Van Hoof: Orestes 2: necessitas, weapons, -, Eur.Or. 947]

[Van Hoof s.v. Orestes 3: desperata salus, inedia, -, Eur.Iph.Taur. 973]

\section{ORONTES}

Orontes, filho de Dídnaso, é um guerreiro da Índia muito temido, até pela sua estatura descomunal. Comanda um exército do rei hindu Deríades aquando da expedição de Dioniso à Índia. É ferido pelo deus e mata-se.

O seu corpo é arrastado pelas águas do Orontes, na Síria, que são rebaptizadas com o nome do herói.

Motivo: impatientia doloris

Modo: afogamento

Temas: Dioniso, hidrónimo, Índia, mito epónimo, paralelo com Héracles, Síria

Fontes:

BNP s.v. Orontes $238-239$ n $^{\circ} 1$ e 7 (não refere)

Grimal s.v. Orontès $331-332 \mathrm{n}^{\circ} 1$

RE s.v. Orontes $1160-1167 \mathrm{n}^{\circ} 2$

Pausânias 8.29.3 (nada diz)

[Van Hoof: não regista]

\section{PACTOLO}

É filho de Zeus e de Leucótea. Desflora a sua irmã Demódice sem o saber, durante os mistérios de Afrodite. Quando se apercebe, atira-se ao rio Crisórroas, na Ásia Menor. O rio toma então o nome de Pactolo.

Motivo: pudor

Modo: afogamento

Temas: Afrodite, Ásia Menor, engano, hidrónimo, incesto com irmã, Lídia, mito epónimo

Fontes:

BNP s. v. Pactolus 321-322 (nada diz)

Grimal s.v. Pactolos 336

RE s.v. Paktolos 2439-2440

Higino, Fábulas, 191 (não refere suicídio)

Ovídio, Met. 11.85-193

[Van Hoof: não regista]

PÂNDROSO (ver Cécrops, filhas de)

[Van Hoof: não consta]

\section{PANGEU}

É um herói trácio, filho de Ares e de Critobulo. Viola a sua filha de forma involuntária. Trespassa-se então com a sua espada numa montanha que passa a chamar-se Pangeu.

Motivo: pudor 
Modo: arma

Temas: incesto involuntário, mito epónimo, orónimo, engano

Fontes:

BNP (não regista)

Grimal s.v. Pangaeos 344-345

RE Pangaion 589-592

[Van Hoof: não consta]

PÁRTENO (ver Molpadia)

[Van Hoof: não consta]

\section{PARTÉNOPE (ver Sirenes)}

Uma das Sirenes, ou Sereias, que se atiram ao mar (cf. Sirenes). O seu corpo dá à costa em Nápoles, onde um monumento assinala o seu culto, ficando a cidade com o seu nome.

Motivo: pudor

Modo: afogamento

Temas: hibridismo, mito epónimo, Itália

Fontes:

BNP s.v. Parthenope $570 \mathrm{n}^{\circ} 1$

Grimal s.v. Parthénopé 349

RE s.v. Parthenope 1934-1936 nº

[Van Hoof s.v. Parthenope: dolor, jumping, +, Dionysios Periegetes]

PÉLIA (ver Melo)

Quando o seu marido, Melo, se enforca ao perder o amigo Adónis, a cipriota Pélia enforca-se na mesma árvore. Afrodite metamorfoseia-a em pomba, ave que é o símbolo da deusa e do amor.

Motivo: dolor

Modo: forca

Temas: Afrodite, amor conjugal, Chipre, perda de marido, pomba

Fontes:

BNP (não consta)

Grimal s.v. Mélos 287

RE s.v. Pelia 308 (parece ser outro mito)

[Van Hoof: não regista]

PELOPEIA (ou Pelópia)

É filha de Tiestes, banido de Micenas pelo seu irmão Atreu, e a viver em Sícion. Um oráculo prediz que o filho que Tiestes tiver com a sua filha o vingará de Atreu, que lhe matara os filhos. Certa noite, quando Pelopeia volta de um sacrifício em Sícion, Tiestes viola-a, gerando Egisto. Pelopeia, sem saber quem é o violador, consegue arrancar-lhe a espada e guardá-la.

Grávida de Egisto, Pelopeia casa com Atreu, seu tio. Expõe a criança, que é recolhida por pastores e alimentada a leite de cabra, cujo nome grego se relaciona 
etimologicamente com o próprio nome de Egisto. Mas Atreu manda buscar Egisto para o criar, sem saber quem é o pai.

Quando Egisto cresce, Atreu encarrega-o de ir a Delfos buscar Tiestes como prisioneiro, com o objectivo de o matar. Egisto obedece. Mas quando Tiestes vê a espada que Egisto empunha, dá-se a anagnórise. Tiestes reconhece o filho, pede que tragam Pelopeia à sua presença e revela-se o segredo do nascimento de Egisto. Pelopeia apossa-se da espada e espeta-a no peito. Egisto arranca-a ainda ensanguentada e vai ter com Atreu, que está a fazer um sacrifício de júbilo pela morte do irmão. Mata-o com a espada e os dois, Egisto e Tiestes, reinarão em conjunto no reino de Micenas.

Motivo: pudor

Modo: arma

Temas: anagnórise, Delfos, estupro do pai, exposição de crianças, Guerra de Tróia, incesto, Micenas, mito etiológico, ódio fraterno, Sícion, tiranicídio

Fontes:

BNP s.v. Pelopeia $702 \mathrm{n}^{\circ} 2$ (mata-se quando Egisto descobre que ela é mãe dele)

Grimal s.v. Atrée 59-60; s.v. Égisthe 134-135; s.v. Pelopia 354 nº 1; s.v. Thyeste 458

RE s.v Pelopia 374-375 n⿳3

Higino, Fábulas, 87, 243.8

[Van Hoof s.v. Pelopeia: pudor, ? , +, Hyg.Fab. 87; 243,8]

\section{PENÉLOPE}

Durante a ausência de Ulisses, chega a desejar uma morte rápida, como a das filhas de Pandáreo. Noutra versão, perante o boato da morte de Ulisses lançado por Náuplio, Anticleia suicida-se e Penélope atira-se ao mar, sendo salva por aves marinhas.

Motivo: dolor

Modo: afogamento

Temas: amor conjugal, engano, Guerra de Tróia, Ítaca, perda do marido, suicídio frustrado

Fontes:

BNP s.v. Penelope 720-722 (não refere suicídio); s.v. Nauplios 2004-2008 (falsa notícia de Náuplio)

Grimal s. v. Pénélope 355-356 (lenda do afogamento); s. v. Pandaréos 343 (desejo de morrer)

RE s.v. Penelope 460-493

[Van Hoof: não consta]

\section{PERDIZ}

Perdiz é meia-irmã de Dédalo, filha de Eupálamo, de Creta. À morte ou exílio do filho, que também se chama Perdiz, enforca-se de desespero.

Os atenienses instituem um culto em sua honra.

Motivo: dolor

Modo: forca

Temas: amor maternal, Creta, mito etiológico

Fontes:

BNP s.v. Perdix 748-749 (não tem esta versão)

Grimal s.v. Perdix $358 n^{\circ} 1$

RE s.v. Perdix $615 n^{\circ} 1$ 
Ovídio, Met.8.236-259 (etiologia do nome da ave)

[Van Hoof: não consta]

\section{PÍLADES (ver Orestes)}

Filho de Estrófio e de Anaxábia ou Anaxíbia, da Fócide, amigo de Orestes e seu parceiro no assassinato de Egisto. Segundo Eurípides, quando Oreste é julgado na Argólide, dispõe-se a morrer com este, uma vez que foi co-autor do crime. Este argumento conjuga-se com a proclamação de que não saberia viver sem o amigo.

Motivo: dolor

Modo: arma

Temas: amizade, Argólide, deus ex machina, Fócide, suicídio frustrado

Fontes:

BNP s.v. Pylades 239-240 n 1 (não menciona suicídio)

Grimal s.v. Orestes 329-331 (não menciona suicídio); s.v. Pylade 402 (não refere suicídio)

RE s.v. Pylades $2077-2084 \mathrm{n}^{\circ} 1$

Eurípides, Orestes, 1035-1084 (Pílades decide suicidar-se juntamente com Orestes); 1091

(Pílades diz que partilha a morte); 1625-1693: Apolo assume a responsabilidade pelo matricídio e salva Orestes, Electra e Pílades)

[Van Hoof s.v. Pylades: dolor, jumping, -, Eur.Or. 1091]

\section{PÍRAMO (ver Tisbe)}

Píramo e Tisbe amam-se e Tisbe engravida antes de se casarem. Desesperada, mata-se. Então Píramo apunhala-se e morre também.

Segundo Ovídio, a lenda passa-se na Babilónia e o casamento é contrariado pelos pais. Num dos encontros secretos, Tisbe esconde-se atrás de uma amoreira, na proximidade do túmulo de Nino e de uma fonte. Aí é atacada e ferida por uma leoa que se aproxima para beber, mas consegue fugir. Quando Píramo chega, vê vestígios ensanguentados das roupas da amada. Julgando-a morta, mata-se com uma espada. $\mathrm{O}$ mesmo fará depois Tisbe, quando regressa e o vê morto.

Os frutos da amoreira, que costumavam ser brancos, passam a vermelho, a cor do sangue dos suicidas.

Noutra versão, apiedados, os deuses transformam-nos em cursos de água da Cilícia: Píramo no rio homónimo; Tisbe numa fonte que lança a sua água nesse rio.

Motivo: dolor

Modo: arma

Temas: amores contrariados pelos pais, Babilónia, Cilícia, engano, mito epónimo, mito etiológico, hidrónimo, sexo pré-matrimonial, suicídio duplo, Romeu e Julieta.

Fontes:

BNP s.v. Pyramus and Thysbe 251-252 nº 2 (lenda da Cilícia)

Grimal s.v. Pyrame 402-403 (não regista entrada para Thysbe; fala em rio da Cilícia)

RE s.v. Pyramos 1-11 no 3 (remete para Thisbe); s.v. Thisbe 286-291 no 1 (rio da Cilícia)

Ovídio, Met. 4.55-166

Higino, Fábulas, 242.5 (Píramo da Babilónia), 243 (Tisbe da Babilónia)

[Van Hoof s.v. Pyramus: desperata salus, weapons, +, Ov.Met. 4.119 sqq.] 


\section{PIRENEU}

Pireneu, rei de Dáulis, na Fócide, assedia as Musas que havia convidado a refugiarem-se em sua casa durante uma tempestade. Quando estas fogem, Pireneu precipita-se do alto de uma torre para as perseguir em seu voo.

Motivo: furor

Modo: precipitação

Temas: assédio sexual, Fócide, Musas, tirano abusador

Fontes:

BNP (não regista entrada)

Grimal s.v. Pyrénée 403

RE s.v. Pyreneus 18-19

Ovídio, Met. 5.269-293 (291: tresloucado)

[Van Hoof: não consta]

\section{PLÊIADES}

Irmãs de Hias e das Híades, são as 12 filhas de Atlas e de Plêione. Acerca da sua lenda existem numerosas variantes. Perseguidas pelo caçador Oríon durante cinco anos, na Beócia, em desespero transformam-se em pombas. Zeus apieda-se e converte-as em constelação.

Noutra versão, teriam morrido de desgosto pela perda ou do pai Atlas ou do irmão Hias.

Motivo: desperata salus

Modo: afogamento

Temas: Beócia, assédio sexual, metamorfose, mito epónimo, astronomia, perda de irmão, perda de pai, pomba

Fontes:

BNP s.v. Hyades 590-591 (forçadas a lançarem-se ao mar); s.v. Hyas 593 (“died of grief”); s.v. Pleiades 375-376

Grimal s.v. Hyades 215; s.v. Hyas 215 (suicídio); s.v. Plêiades 379 (não refere morte)

Higino, Fábulas, 192, 248

[Van Hoof: não regista entrada]

\section{POLIDORA}

É filha de Meleagro e de Cleópatra, mulher de Protesilau, de Cálidon. Também é chamada Laodamia ou Hipodamia. Mata-se depois da morte prematura do marido.

Motivo: dolor

Modo: arma

Temas: amor conjugal, Cálidon, Etólia, perda do marido

Fontes:

BNP s.v. Polydora $519 \mathrm{n}^{\circ} 4$

Grimal s. v. Polydora 384 (não é esta)

Pausânias, 4.2.7

RE s.v. Polidora 1604-1607 no 5

[Van Hoof: não regista entrada]

POLIMEDE (ver Alcímede)

[Van Hoof: não consta] 
POLÍMELE (ver Alcímede)

BNP s.v. Polymele $527 \mathrm{n}^{\circ} 1$ (remete para Aeson e para Iason)

RE s.v. Promachos 642-646 n 11 (Prómaco é filho de Éson e de Polímele, é morto em criança por Pélias); s.v. Polymela oder Polymele 1776-1767 "Name mytischer Frauen 'designação de mitónimos femininos" n⿳1 1 (mulher de Éson, mãe de Jasão)

[Van Hoof: não consta]

\section{POLÍXENA}

É filha de Príamo e de Hécuba, de Tróia. Teria sido sacrificada sobre o túmulo de Aquiles, por exigência do espírito deste e por intermédio de Pirro (ou Neoptólemo), filho de Aquiles, e de Ulisses, e para garantir o regresso dos Gregos no final da Guerra de Tróia.

Segundo Filóstrato, trespassa-se com uma espada no túmulo de Aquiles, por amor.

Motivo: dolor

Modo: arma

Temas: amor, Aquiles, Guerra de Tróia, paralelo com Ifigénia, sacrifício feminino

Fontes:

BNP s.v. Polyxena 538-539

Grimal s.v. Polyxène 387-388

RE s.v. Polyxena $1840-1850$

Séneca, Troianas, 1148-1152 (Polixena como que se oferece ao golpe final)

Higino, Fábulas, 110 (não refere suicídio)

[Van Hoof s.v. Polyxena: dolor, weapons, +, Philostr.Her. 51,2-6]

PRAXÍTEA (ver Erecteu, filhas de)

Filha do rei Leos de Atenas. Juntamente com as duas filhas, ou é sacrificada ou oferecese em sacrifício para salvar Atenas da peste.

Motivo: devotio

Modo: arma

Temas: Atenas, peste, sacrifício feminino, suicídio colectivo

Fontes:

BNP s.v. Praxithea $788 n^{\circ} 2$

Grimal s.v. Praxithea 391-392 $\mathrm{n}^{\circ} 1$ (só refere sacrifício das filhas para garantir vitória)

RE s.v. Praxithea 1809-1811 no 3 (exemplos de sacrifícios femininos)

[Van Hoof: não consta]

\section{QUÍRON}

Quíron é um centauro e é imortal. Seu pai é Cronos e sua mãe Fílira. Para se unir a ela, Cronos transfigurou-se em cavalo. Quíron é também um justo e é amigo dos homens. Quando Héracles massacra os Centauros, Quíron luta a seu lado. Mas, uma flecha envenenada cai da aljava de Héracles e atinge-o. A ferida é incurável e Quíron deseja morrer, ele que é imortal. Então, Prometeu dá-lhe a sua mortalidade e Quíron cede-lhe a sua imortalidade. É transformado em constelação.

Motivo: impatientia doloris

Modo: arma 
Temas: astronomia, mito epónimo, hibridismo, filantropia, renúncia à imortalidade, suicídio manu aliena

Fontes:

BNP s.v. Chiron 233-234; s.v. Prometheus 6-10

Grimal s.v. Prométhée 397; s.v. Chiron 90

RE s.v. Chiron 2302-2308 $\mathrm{n}^{\circ}$

Ovídio, Fastos, 5.379-414

Apolodoro, Biblioteca, 2.5.4, 11

[Van Hoof: não consta)

\section{SAFO}

Safo está apaixonada por Fáon, um herói da ilha de Lesbos, de uma beleza invulgar. Mas ele despreza-a. Safo precipita-se então do alto da falésia de Lêucade para o mar.

Nesse local, realiza-se um ritual anual expiatório em que um condenado é precipitado.

Motivo: dolor

Modo: afogamento

Temas: beleza masculina, Lesbos, mito etiológico, sacrifícios humanos

Fontes:

BNP s.v. Sappho 961-964; s.v. Phaon 919-920 nº 1

Grimal (não regista entrada); s.v. Phaon 364

RE s.v Sappho 2357-2385, esp. 2364

Ovídio, Ep. 15

[Van Hoof s.v. Sappho: dolor, jumping, +, Amp. 8,4]

\section{SÁGARIS}

Ságaris, ou Sângaris, é um dos filhos de Midas, ou de Mígdon e de Alexírroe. Como não presta culto a Cíbele, a deusa enlouquece-o. Atira-se ao rio Xeróbates, que passa a chamar-se Sangário.

Também se designava ságaris o instrumento de castração.

Motivo: furor

Modo: afogamento

Temas: Ásia (Lídia), Cíbele, mito epónimo, hidrónimo, vingança divina

Fontes:

BNP s.v. Sagaritis $865-866$

Grimal s.v. Sagaris $413 \mathrm{n}^{\circ} 2$

RE s.v. Sagaris $1733-1734 n^{\circ} 1$; s.v. Sagaritis $1734-1736$

[Van Hoof: não consta]

\section{SÁLMACIS}

Hermafrodito, natural da Frígia, levava uma vida errante. Na Cária, Sálmacis, a ninfa de um lago, apaixona-se por ele. Quando Hermafrodito aí mergulha, Sálmacis abraça-o mas ele repudia-a. Então, a ninfa pede aos deuses que os seus dois corpos nunca mais se separem. Os deuses assim o fazem e de ora em diante, a pedido de Hermafrodito, todos aqueles que tomarem banho no lago Sálmacis perdem a virilidade.

Motivo: desperata salus

Modo: inedia 
Temas: Ásia, hermafroditismo, metamorfose, mito epónimo, mito etiológico, ninfa

Fontes:

BNP s.v. Hermaphroditus 207-208; Salmacis 896

Grimal s.v. Hermaphrodite 206

Ovídio, Metamorfoses, 4.274-388.

[Van Hoof: não consta]

\section{SELEMNO}

Árgira é uma ninfa de uma fonte da Arcádia e está apaixonada pelo pastor Selemno. O seu amor dura enquanto Selemno é jovem. Quando este perde a beleza, ela abandona-o. Desesperado, Selemno deixa-se consumir e é transformado em rio por Afrodite. Apesar da transformação, continua a sofrer até Afrodite lhe conceder o dom de esquecer todas as suas dores. É por essa razão que os homens e mulheres que se banham no Selemno esquecem os seus desgostos de amor.

Motivo: dolor

Modo: inedia

Temas: Afrodite, Arcádia, bucolismo, desamor, diferença de idades, mito etiológico

Fontes:

BNP (não regista)

Grimal s.v. Argyra 50

RE s.v. Sele $1135-1136$ n $^{\circ} 2$ Sile / Selemnos; s.v. Argyra 799-801 n³

Pausânias, 6.23.2: morre de amor, 7.23.2

[Van Hoof: não consta]

\section{SELENE}

Selene é filha de Basileia. Casa com o seu irmão Hipérion e gera Selene (a Lua) e Hélio (o Sol). Despeitados, os outros Titãs matam o marido-irmão e afogam Hélio, o filho, no rio Eridano. A dor de perder o irmão leva Selene a precipitar-se do telhado de sua casa. O mito mais comum é o dos amores de Selene e Endímion.

Motivo: dolor

Modo: precipitação

Temas: astromonia, casamento com irmão, Cíbele, incesto, amor conjugal, Arcádia

Fontes:

BNP s.v. Selene 210-211 (não explicita esta versão]; (não regista entrada Basileia)

Grimal s.v. Basiléia 63 (suicídio de Selene); s.v. Sélénè 418 (não refere este mito, só os amores com Endímion)

RE s.v. Sele / Selene 1136-1144 no 1

[Van Hoof s.v. Selene: dolor, jumping, +, Diod. 3,57,5]

\section{SEMÍRAMIS (ver Honetes)}

Semíramis seria filha da divindade Dérceto. Casa-se com o rei Nino, enviuva e torna-se rainha da Assíria. É avisada pelo oráculo egípcio de Ámon de que morrerá quando seu filho conspirar contra ela. Desta forma, Semíramis entrega-lhe o poder e desaparece, transformada em pomba.

Imola-se na pira à morte do seu cavalo — de que gostava tanto que tinha coito com ele. 
Motivo: dolor

Modo: imolação

Temas: animais (cavalo), bestialismo, Assíria, Babilónia, metamorfose, oráculo, pomba

Fontes:

BNP s.v. Semiramis 237 (não refere suicídio, mas abdicação); s. v. Onnes (remete para Semiramis)

Grimal s.v. Sémiramis 419 ; s. v. Nios 317

RE s.v. Semiramis Suppl.7 1204-1210 nº 1, esp.1208

Higino, Fábulas, 243.8 perda do cavalo (ver Honetes)

Plínio o Naturalista, História Natural, 8.155

[Van Hoof s.v. Semiramis: dolor, fire, +, Hyg.Fab. 242,4 (referência errada)]

SEREIAS (ver Sirenes)

SIDE

Side é uma jovem que foge às perseguições do seu pai e acaba por se suicidar sobre o túmulo da sua mãe. Do seu sangue, os deuses fazem crescer uma romãzeira, árvore que tem o mesmo nome da jovem. O pai é transformado em milhafre. Segundo diziam, este pássaro nunca poisa em cima de uma romãzeira.

Motivo: desperata salus

Modo: arma

Temas: assédio do pai, metamorfose, mito etiológico, simbologia animal

Fontes:

BNP s.v. Side 433-435 (esta entrada não corresponde a mitónimo)

Grimal s.v. Sidè $422 \mathrm{n}^{\circ} 5$

RE s.v. Side 2208-2211 n 12 (nachstellen 'perseguir')

[Van Hoof: não consta]

SILEU, FILHA de (ver Héracles 2)

Héracles mata o prepotente e injusto Sileu, da Tessália, e é acolhido em casa do irmão deste, Diceu 'O Justo'. Aí, apaixona-se pela filha do assassinado, a qual habitava com o tio. Quando tem de se ausentar por algum tempo, a jovem não consegue suportar a separação e morre. Ao regressar, Héracles quer atirar-se à pira fúnebre, mas é impedido.

Motivo: dolor

Modo: inedia

Temas: Héracles (trabalhos de), ausência do amado, Tessália

Fontes:

BNP s.v. Herakles 156-163 (nada diz); s.v. Syleus 986 (não refere suicídio)

Grimal s.v. Sylée 432-433; s.v. Héraclès 187-203, esp. 200

RE s.v. Syleus 1039-1040

[Van Hoof: não consta] 
SIRENES (ou Sereias)

As Sirenes são metade mulher, metade pássaro. O seu número varia consoante a tradição. Em geral fala-se em três. Vivem numa ilha do Mediterrâneo e o seu canto atrai os marinheiros, fazendo-os naufragar e devorando-os.

Quando Ulisses passa por estas paragens, a sua curiosidade e os conselhos de Circe conduzem-no ao seguinte estratagema: os seus homens tapam os ouvidos com cera e ele é preso ao mastro do navio. Assim, Ulisses ouve o canto das Sirenes mas não vai ao encontro delas. Despeitadas por terem falhado, as Sirenes atiram-se ao mar e morrem afogadas.

Motivo: pudor

Modo: afogamento

Temas: canto mágico, Circe, Guerra de Tróia, hibridismo, Mediterrâneo, música, Ulisses

Fontes:

BNP s.v. Sirens 504-505 ("The Siren's committing suicide because of the defeat is not found in literature before the Hellenistic period"; Lycophr.714)

Grimal s.v. Sirènes 424-425

RE s.v. Sirenen 288-308 especialmente 295 (história do suicídio num vaso grego de 600 a.C, Museu Britânico E 440)

Higino, Fábulas, 141.2

Ovídio (não menciona a morte em nenhuma das referências)

[Van Hoof: não consta]

\section{SOLUNTE}

No regresso da expedição contra as Amazonas, Teseu traz a jovem Antíope consigo no barco. Solunte, um dos companheiros da expedição, apaixona-se por ela e confessa-se a um amigo. Este revela o segredo a Antíope, que recusa Solunte. Solunte atira-se a um rio da Bitínia e morre afogado. Teseu dá ao rio o nome do jovem.

Motivo: dolor

Modo: afogamento

Temas: Amazonas, Ásia (Bitínia), hidrónimo, mito epónimo

Fontes:

BNP (não regista)

Grimal s.v. Soloïs 427

RE s.v. Soloeis $935 n^{\circ} 1$ (não refere lenda)

Plutarco, Teseu, 26

[Van Hoof s.v. Solois: dolor, jumping, +, Plout.Thes. 26,3-5]

\section{TÁNAIS}

Deus-rio, filho de Oceano e de Tétis, ou de Beroso e da Amazona Lisipe, numa lenda tardia. De entre os deuses, apenas cultua Ares e abomina as mulheres. Afrodite decide puni-lo provocando-lhe um amor incestuoso pela sua mãe. Desesperado, Tánais só encontra um meio para fugir a esta paixão: atira-se ao rio, até então chamado Amazónio e que passará a chamar-se Tánais (actual Don).

Motivo: desperata salus

Modo: afogamento 
Temas: Afrodite, Amazonas, Ásia, hidrónimo, incesto com mãe, misoginia, mito epónimo, vingança divina, região do Don

Fontes:

BNP s.v. Tanais 130-131 nº 1 (não refere a lenda)

Grimal s.v. Tanaïs 435

RE s.v. Tanais 2162-2171

[Van Hoof: não consta]

\section{TEANO}

Mulher do rei Metaponto, da Icária, Ásia. Sendo estéril, o marido ameaça repudiá-la. Ela recolhe então duas crianças abandonadas, filhas de Neptuno e Melanipa, e apresenta-as ao rei como sendo seus filhos. Mais tarde dará à luz dois rapazes. Mas o rei prefere os outros dois e não aceita o conselho de os fazer desaparecer. Teano convence então os filhos verdadeiros a matarem os outros dois durante uma caçada. Mas são os jovem recolhidos que sobrevivem e trazem o corpo dos filhos verdadeiros para o palácio. Teano suicida-se com uma faca de caça.

Motivo: conscientia

Modo: arma

Temas: Ásia, caçada, engano, esterilidade, exposição de crianças, poder feminino, repúdio

Fontes:

BNP s.v. Theano $377 \mathrm{n}^{\circ} 2$

Grimal s.v. Théano 447 (não refere suicídio)

RE s.v. Theano $1377-1381 \mathrm{n}^{\circ} 3$

Higino, Fábulas, 186.7 (versão apresentada)

[Van Hoof s.v. Theano: desperata salus, weapons, Hyg.Fab. 186]

\section{TEMISTO}

É filha de Hipseu e de Creúsa. Na tragédia Ino, de Eurípides, que utiliza uma versão beótica da lenda, Atamante, julgando Ino morta (ver entrada Ino), casa em terceiras núpcias com Temisto, filha de Hipseu. Desta união nascem dois filhos, Orcómeno e Esfíngio. Mas Ino junta-se às Bacantes e um dia infiltra-se no palácio vestindo o papel de criada. Temisto sabe que Ino não morreu e quer matar-lhe os filhos. Confia-se à nova serva e ordena-lhe que vista as crianças de Ino de preto e as suas de branco, para as distinguir na escuridão. A pretensa serva troca as roupas e Temisto, por engano, mata os seus próprios filhos. Quando se apercebe do acto que cometeu, mata-se.

Motivo: conscientia

Modo: ?

Temas: Beócia, engano, infanticídio, noverca, Tessália, triângulo amoroso

Fontes:

BNP s.v. Athamas 229-230; s.v. Ino 821-822; s.v. Themisto 428-429 nº 1

Grimal s.v. Athamas 56-57; s.v. Themisto 448

RE s.v. Themisto $1680-1684 \mathrm{n}^{\circ} 1$

Higino, Fábulas, 1, 4, 239, 243.5

[Van Hoof s.v. Themisto: dolor, ?, Hyg.Fab. 1,2] 


\section{TÉSTIO}

Téstio é rei de Plêuron, na Etólia. Após longa ausência, regressa e encontra o seu filho Cálidon deitado ao lado da mãe. Pensando tratar-se de incesto, mata os dois. Mais tarde, conhecendo o erro, atira-se ao rio Áxeno, desde então rebaptizado com o seu nome, Téstio. Virá depois a chamar-se Aqueloo.

Motivo: dolor

Modo: afogamento

Temas: engano, Etólia, hidrónimo, incesto, mito epónimo

Fontes:

BNP s.v. Thestius 579-580 ("finds his son Calydon and his wife together, thinks there has been adultery and kills him"; s.v. Calydon 1008-1009 n² ("sees him with his mother and kills him".

Grimal s.v. Calydon $76 \mathrm{n}^{\circ} 2$ (incesto); s.v. Thestios 456 (nada diz, remete para Cálidon)

RE s.v. Thestios 184-186 no 1 (não explicita a morte)

Apolodoro, 1.7.7 (nada diz)

Higino, Fábulas, 250 (não refere morte)

Pausânias, 3.13.8

[Van Hoof: não consta]

\section{TESTOR (ver Ídmon)}

É filho de Apolo e de Laótoe e o adivinho dos Argonautas, sendo também chamado Ídmon. Quando vê sua filha Teónoe raptada por piratas, parte em sua busca. Mas naufraga, é preso na Cária e vendido como escravo ao rei local, a quem também a sua filha havia sido vendida. Entre aventuras novelescas, encontra-se na prisão com outra filha, Leucipe, que se disfarçara de homem. É justamente esta que lhe arranca das mãos a espada com que ia matar-se, desesperado com a perda de ambas as filhas. $\mathrm{O}$ final feliz é consumado com o reconhecimento de Teónoe.

Motivo: desperata salus

Modo: arma

Temas: disfarce, piratas, mulher travestida de homem (teatro), suicídio frustrado, viagens, final feliz

Fontes:

BNP s.v. Thestor $580 \mathrm{n}^{\circ} 1$

Grimal, s.v. Théonoé $448-449$ n²; s. v. Thestor 456 remete para Théonoé

RE s.v. Thestor $185 \mathrm{n}^{\circ} 1$

Higino, Fábulas, 190

[Van Hoof: não consta]

\section{TEUCRO}

Filho de Télamon e de Hesíone, meio-irmão de Ájax, natural de Salamina. Nos funerais de Ájax, protege o cadáver de ofensas. É impedido de se suicidar. No regresso, anda errante por todo o Mediterrâneo.

Motivo: dolor

Modo: arma

Temas: amor fraternal, Egina, Guerra de Tróia, navegações, Salamina de Chipre, suicídio frustrado, Tróia 
Fontes:

BNP s.v. Teucer $330-331 \mathrm{n}^{\mathrm{o}} 2$

Grimal, s.v. Teucer $445-446 \mathrm{n}^{\circ} 2$

RE s.v. Teukroi 1121-1134 n²

[Van Hoof: não consta]

TIMÁGORAS 1 (ver Meles 1 e 2; ver Timágoras 2)

Em Atenas, o jovem e caprichoso Meles despreza o amor do meteco Timágoras, impondo-lhe toda a espécie de duras provas. Acaba por o desafiar a atirar-se do alto dos rochedos da Acrópole. Timágoras assim faz e salta para a morte. Desesperado, Meles também se atira e morre.

Em memória deste episódio, erige-se um altar a Ânteros ('Amor Correspondido'), onde os estrangeiros domiciliados em Atenas celebram um culto que lhes é próprio.

Motivo: furor

Modo: precipitação

Temas: Atenas, meteco, mito etiológico, servitium amoris, suicídio duplo

Fontes:

BNP s.v. Meles 628; s.v. Timagoras 681 (não regista esta entrada)

Grimal s.v. Mélès 286 (não regista Timágoras)

RE Meles 491-492, $\mathrm{n}^{\circ} 1$ (duas versões)

Pausânias, 1.30 .1

[Van Hoof s.v. Timagoras: iactatio, jumping, +, Paus. 1,30,1]

TIMÁGORAS 2 (ver Timágoras 1; ver Meles 1 e 2)

Existe uma história similar à de Timágoras 1, de Eliano, mas entre dois aristocratas atenienses, onde os nomes são iguais mas a relação amorosa é inversa: o amado Meles ou Melito executa todas as exigências de Timágoras. Quando lhe traz aves raríssimas e não o demove, atira-se do alto de um rochedo. Timágoras segue o amante.

Motivo: furor

Modo: precipitação

Temas: Atenas, desamor, homo-erotismo, servitium amoris, suicídio duplo

Fontes:

BNP s.v. Meles 628

Grimal s.v. Mélès 286

RE Meles 491-492 $\mathrm{n}^{\circ} 1$ (ambas as versões)

Pausânias, 1.30 .1

[Van Hoof: não consta]

TISBE (ver Píramo)

Píramo e Tisbe amam-se e Tisbe engravida antes de se casarem. Desesperada, mata-se. Então Píramo apunhala-se e morre também. Segundo Ovídio, a lenda passa-se na Babilónia. Píramo e Tisbe amam-se, mas o casamento é contrariado pelos pais. Num dos encontros secretos, Tisbe esconde-se atrás de uma amoreira, na proximidade do túmulo de Nino e de uma fonte. Aí é atacada e ferida por uma leoa que se aproxima para beber, mas consegue fugir. Quando Píramo se aproxima, vê vestígios ensanguentados 
das roupas da amada. Julga-a morta e mata-se com uma espada. O mesmo fará depois Tisbe, quando regressa e o vê morto.

Os frutos da amoreira, que costumavam ser brancos, passam a vermelho, a cor do sangue dos suicidas.

Noutra versão, apiedados, os deuses transformam-nos em cursos de água da Cilícia:

Píramo no rio homónimo; Tisbe numa fonte que lança a sua água nesse rio.

Motivo: dolor

Modo: espada

Temas: amores contrariados pelos pais, Ásia (Babilónia, Cilícia), mito etiológico, flora, hidrónimo, sexo pré-matrimonial, suicídio duplo

Fontes:

BNP s.v. Pyramus and Thysbe 251-252 nº 2 (rio da Cilícia)

Grimal s.v. Pyrame 402-403 (não regista entrada para Thysbe; rio da Cilícia; rio da Sicília, na tradução portuguesa, errada)

RE s.v. Thisbe 286-291 nº 1 (rio da Cilícia)

Ovídio, Met. 4.55-166 (acrescenta a arma do suicídio)

Higino, Fábulas, 242, 243.8

[Van Hoof s.v. Thisbe: desperata salus, weapons, +, Ov.Met. 4,162]

\section{VALÉRIA (ver Valério)}

Para fazer cessar uma epidemia que caíra sobre Falérios, um oráculo ordena o sacrifício anual de uma virgem a Juno. Quando Valéria empunha o cutelo para se imolar, uma águia arrebata-o e deixa cair um bastão sobre o altar, junto de um martelo ritual. Valéria compreende que basta sacrificar uma vitela.

Ao consumar o sacrifício, canta a palavra grega errhoso, correspondente ao latim vale 'saúde, adeus' e explicação etiológica do nome Valéria e da cessação da peste.

Motivo: devotio

Modo: arma

Temas: suicídio frustrado, Falérios, mito etiológico; sacrifícios humanos substituídos, Túsculo

Fontes:

BNP Valeria $166 \mathrm{n}^{\circ} 5$ (condiz com Grimal; acrescenta etiologia)

Grimal s.v. Valéria 475

RE (não consta)

Plutarco, Obras Morais, 311ab (ela e a criança sobrevivem, ela tentara abortar; pai mata-se depois do nascimento da criança)

[Van Hoof: Valeria Tusculanaria: pudor, jumping, -, Plout.Mor. 311B]

\section{VALÉRIO (ver Valéria)}

Figura mitológica de Túsculo e vítima do amor incestuoso de sua filha Valéria. Esta, com a cumplicidade da ama, embriaga o pai e dorme com ele de rosto velado, dizendo ser uma donzela vizinha que quer manter o anonimato. Foi gerado Egipã, que os romanos identificam com Silvano e Pã. Ao conhecer a verdade, Valério precipita-se de um rochedo.

Motivo: pudor

Modo: precipitação 
Temas: engano, incesto involuntário, Túsculo

Fontes:

BNP s.v. Valerius $169-183 \mathrm{n}^{\circ} 1$

Grimal (não regista)

RE (não consta)

Plutarco, Obras Morais, 311ab

[Van Hoof: não consta] 


\section{Temáticas Emergentes}

Nos mitos descritos, as constâncias detectadas fazem emergir temáticas que realçam contextos geográficos, culturais, antropológicos, etnográficos, religiosos e científicos, tão abundantes que seria impossível tratá-los no âmbito desta dissertação. Faremos portanto um esquisso breve.

Um aspecto que sobressai dos mitos é a grande quantidade de relações incestuosas. A este propósito, reveja-se uma das particularidades das leis de Sólon: " $\mathrm{Na}$ verdade, o ateniense Sólon permitiu o casamento com (meias-irmãs) filhas do mesmo pai, mas proibiu-o com as filhas da mesma mãe ${ }^{, 57}$. Ou seja, era permitido a um homem casar-se com a sua meia-irmã, desde que tivessem mães diferentes. Este "alargamento" generoso dos espartilhos do incesto poderá também evidenciar nesse mundo mitológico, espelho reflector do mundo real, a abundância desta temática. Inclusivamente, muitas vezes o incesto é produto de um oráculo, a pedra de toque necessária e catalisadora para algo se concretizar. Veja-se o caso de Pelopeia: o oráculo diz a seu pai que o filho que terá com ela, sua filha, o vingará de seu irmão Tiestes. A força destas relações tabu é tal, que nos chegamos a deparar com situações em que o incesto é quase duplo, como na lenda de Evópis, que casa com o tio mas ama o irmão.

Os adultérios femininos desocultam alguns cenários sociais muito interessantes. Por exemplo, as mulheres praticam-no sobretudo no seio da casa, no oikos e com estrangeiros. Este facto permite-nos fazer duas leituras. Primeiro, a de que muito do universo feminino está efectivamente confinado à casa e, portanto, o adultério acontece mais naturalmente nesse contexto doméstico. Segundo, percepciona-se uma aceitação fácil do Outro, enquanto estrangeiro. É o paradigma do príncipe naufragado que encanta a princesa, é Calipso e Ulisses.

\footnotetext{
${ }^{57}$ F 47 R (Fílon, De spec.leg.3.22) apud D. Leão 2001365.
} 
Noutras situações, este modelo feminino assume outros contornos, mais retorcidos, permitindo identificar padrões ricos de densidade psicológica dos personagens. É o caso de Astidameia e de Cleobeia. Os amores estigmatizados que sentem para com o estrangeiro que "aportou" em seus lares, fá-las-á terrivelmente audazes no sofrimento e, consequentemente, também na vingança. Nestes cenários, assistimos à cristalização de estereótipos: a mulher má, como Hipodamia, que incita os filhos a matarem o meio-irmão e seu enteado, ou a noverca, encarnada magistralmente na figura de Fedra, antagónica da figura da mãe, boa e abnegada. Aliás, a carga pejorativa que a noverca encerra, espraia-se por vezes até às margens da misoginia, Hipólito assim o demonstra.

Um conjunto de personagens transporta múltiplas luzes que permitem aprofundar análises históricas e sociológicas e que fazem apelo a aspectos de novelas, a tópicos literários de bucólicas e romances. Por exemplo, reconhece-se o serviço amoroso (servitium amoris) em Leucocamante, que impõe duras tarefas ao apaixonado e, de forma muito expressiva, identificamo-lo também em Timágoras e Meles. Atravessa-se a temática dos sofrimentos de amor (erotika pathemata) em Calírroe 1. Encontra-se o tópico da vida selvagem (theriodes bios) em Hipólito, que, a par da leitura misógina já referida, também revela subjugação à natureza, à solidão, ao recolhimento, à devoção a Ártemis, deusa virgem da caça.

Existem lendas que classificámos de histórias paralelas, quer por corresponderem a um padrão de situações idênticas, quer pela moral subjacente ou pelo impacto cultural e sociológico posterior. Por exemplo, na história de Erígone, a quem é revelado o sítio onde se encontra seu pai morto, privado de sepultura, sobressai a mesma problemática vigente em Antígona. Na lenda de Cálamo reencontramos a morte e o renascimento que a lenda de Fénix também encerra. A história de Eveno, que matava todos os pretendentes da sua filha Marpessa e ornava o templo de Posídon com os seus crânios, plasma-se naturalmente em Enómao e nas suas acções para com a sua filha Hipodamia.

Mas as semelhanças mais carismáticas, no sentido em que são mitos explicativos de ritmos cíclicos e de socialização, residem naquele subgrupo das lendas etiológicas, que retrata festividades e celebrações ${ }^{58}$. Por exemplo, Cárila é génese de um ritual catártico e evocativo de generosidade para com o povo. Dáfnis é origem de celebração

\footnotetext{
${ }^{58}$ Ver gráfico IV
} 
religiosa e sacrificial. Muitas vezes estes rituais sofrem evoluções no sentido de um melhoramento civilizacional, como no caso das suas companheiras de Erígone 2, que dão origem ao festival dos Aiora, em Atenas, durante o qual se suspendem raparigas às árvores que mais tarde serão simples efígies.

Inserimos o suicídio por mão alheia (manu aliena) nos temas, mas esta expressão engloba aqueles que pedem a outrem que os mate. Num indivíduo que está na posse das suas capacidades físicas, esse pedido pode ser entendido como uma evidência de fragilidade perante o confronto com a situação, ou tão-somente como o desejo de não vivenciar o fardo desta experiência na solidão. Nesta conjuntura última, poderíamos acolher o escravo Drímaco, o qual, cansado de viver entre perigos e fugas, pede ao amado que o degole. No entanto, é evidente que esta perspectiva é baseada na nossa contemporaneidade e impossível de clarificar. O suicídio manu aliena também se apresenta em contextos mais enviesados, onde não existe um pedido explícito, como em Drímaco, mas sim a demanda convicta de uma situação que leve ao final desejado. Por exemplo, Euquenor parte para a guerra sabendo que vai morrer. Procura portanto conscientemente a morte, que acontece por uma seta de Páris.

A quantidade de temas sugeridos na pesquisa efectuada revelou-se tão pujante que entendemos ser mais sugestivo pô-los também no aparato crítico. Desta base, seleccionámos em geral três temas que surgem no quadro descritivo que contém todas as entradas (ver Quadro, no final dos anexos). Além disso, também referenciámos o local onde acontece o suicídio, o que nos dá algumas luzes sobre esta "diáspora suicidária”. Esta metodologia operativa permitiu ter uma visão de conjunto única sobre o assunto. 


\section{Conclusão}

Depois do longo caminho percorrido, sentimos que muito há ainda por percorrer devido à riqueza da matéria-prima em questão. O corpus identificado alargou de forma considerável as tentativas de seriação de outros estudiosos. A tipologia adoptada, sem deixar de valorizar a de Van Hoof, tornou mais clara a tipificação, sobretudo dos motivos, e corrigiu vários casos classificados de outra forma.

Juntar o suicídio ao mito clássico significou aglomerar, sob estes dois gigantes, histórias lendárias cujo denominador comum se caracterizou por uma intenção, concretizada, de pôr termo à vida. Os suicídios frustrados, abortados por outrem, também foram valorizados, pois cortá-los deste conjunto seria necessariamente empobrecê-lo da sua verdadeira dimensão.

Nas concretizações dessas mortes, surpreendeu-nos também o encontro com as não mortes, ou seja, com as metamorfoses, formas de vida outras que constituem linhas inquebrantáveis de continuidade. Estas circunstâncias permitiram-nos mergulhar em histórias soberbas, no dramatismo e nos sentimentos humanos extremos, onde os deuses estão sempre vigilantes na aplicabilidade do princípio de Némesis.

A construção mítica, resultado de um enorme espectro temporal, limitado a jusante pela época micénica e a montante pelo Império Romano, não se distancia da do mundo real. É evidente que decorre da sua matriz identitária um mimetismo da vivência dos homens de então. Percorrendo a plêiade de temas sugeridos, delineiam-se com muita facilidade contextos geográficos, movimentos migratórios, a colonização grega da Ásia Menor, temáticas literárias, arquétipos de personalidade e indicações sobre mentalidades. Observámos, inclusive, que, na bibliografia analisada, os personagens 
míticos e os reais "coabitam" lado a lado, muitas vezes sem referência a priori especificada sobre se são provenientes de um mundo ou do outro. E essa razão reside no facto desse mundo, o mítico, ser resultado visceral desse outro, o real.

Muitos mitos estão relacionados com a Guerra de Tróia e com os poemas homéricos, o que nos leva a concluir que o grande fundo temático é anterior ao séc. VII e que atesta a formidável perenidade desse ciclo épico, muito embora ele também tenha absorvido continuamente o espírito do tempo, até aos finais da Antiguidade.

Elaborámos as causae moriendi com base em termos e conceitos da Antiguidade. Algumas revelaram características tremendamente constantes no tempo e universais no sentir, como sejam a dor (dolor). Mas noutras, encontrámos marcas indeléveis de um outro tempo, como em Iactatio e na expressão paradigmática que a acompanha, Iactatio, ut quidam philosophi, ou seja, a jactância de certos filósofos, na visão da jurisprudência romana, que nos transporta para um acto a um tempo filosófico e teatral. Aliás, observámos que no Mundo Antigo, ao invés do actual, onde os contextos suicidários se enquadram fundamentalmente num acto solitário, essas mortes eram muitas vezes públicas ou, pelo menos, socializadas.

Algumas classificações, como pudor e conscientia, esgrimem noções de crime voluntário ou involuntário, dicotomias entre culpa e mancha, às quais os personagens se submetem com paixão e ardor. Noutras, como em devotio, atravessam-se actos heróicos, muitas vezes com a intervenção de oráculos. Esta tipologia, em particular, permitiu-nos ver que as mulheres, tal como os homens, também se matam por abnegação e sacrifício pela causa comum, não é só o oikos que é palco feminino.

A quantidade tão expressiva de mitos etiológicos, esses mitos didácticos que operam no domínio explicativo das ciências, sobretudo da Botânica, da Astronomia, dos fenómenos naturais, das particularidades geográficas, assim como das vivências culturais, permite-nos, com uma margem de confiança bastante grande, afirmar que os mitos evidenciam de forma privilegiada a tentativa de racionalização grega.

Nos modi moriendi, o mais numeroso é o afogamento. Ora, se juntarmos isto ao grande número de mitos epónimos, sobretudo na atribuição de nomes a rios, a mares, a particularidades do litoral e a ilhas, sobressai de forma muito clara um padrão que nos permite ver distintamente aquilo que emerge desta realidade e a sintetiza: a água. Sob o signo deste elemento, identificaram-se muitos dos mitos do Mundo Clássico, e isso remete-nos para a importância deste elemento como gerador, formador e modelador de civilizações. 
Em suma, esta informação mitológica permitiu-nos identificar padrões sociológicos que sobressaem da planície narrativa e identificar fios condutores que deixam inferir práticas culturais desse Mundo Antigo. Ajudou-nos a plasmar as narrativas ao próprio contexto geográfico e a observar o que de tão profundo as une, aquartelando as histórias por semelhanças novelescas e concordâncias morais. Identificámos discursos no feminino e no masculino. Fizemos emergir o paganismo e os seus múltiplos fiordes nas estruturas sociais, nos espaços privados e na vivência dos homens de então. Tentámos refazer a História com as muitas histórias que aqui se enlaçam. Afinal, foi isso que se pretendeu desde o início. 
VI. Apêndice - Tratamento Estatístico

Tabela 1

\begin{tabular}{|l|r|}
\hline Mitos Epónimos & 63 \\
\hline Dos quais Hidrónimos & 27 \\
\hline Mitos Etiológicos & 55 \\
\hline Metamorfoses & 29 \\
\hline Das quais com Mitos Epónimos e Etiológicos & 8 \\
\hline Total Mitos Epónimos e Hidrónimos & 105 \\
\hline
\end{tabular}




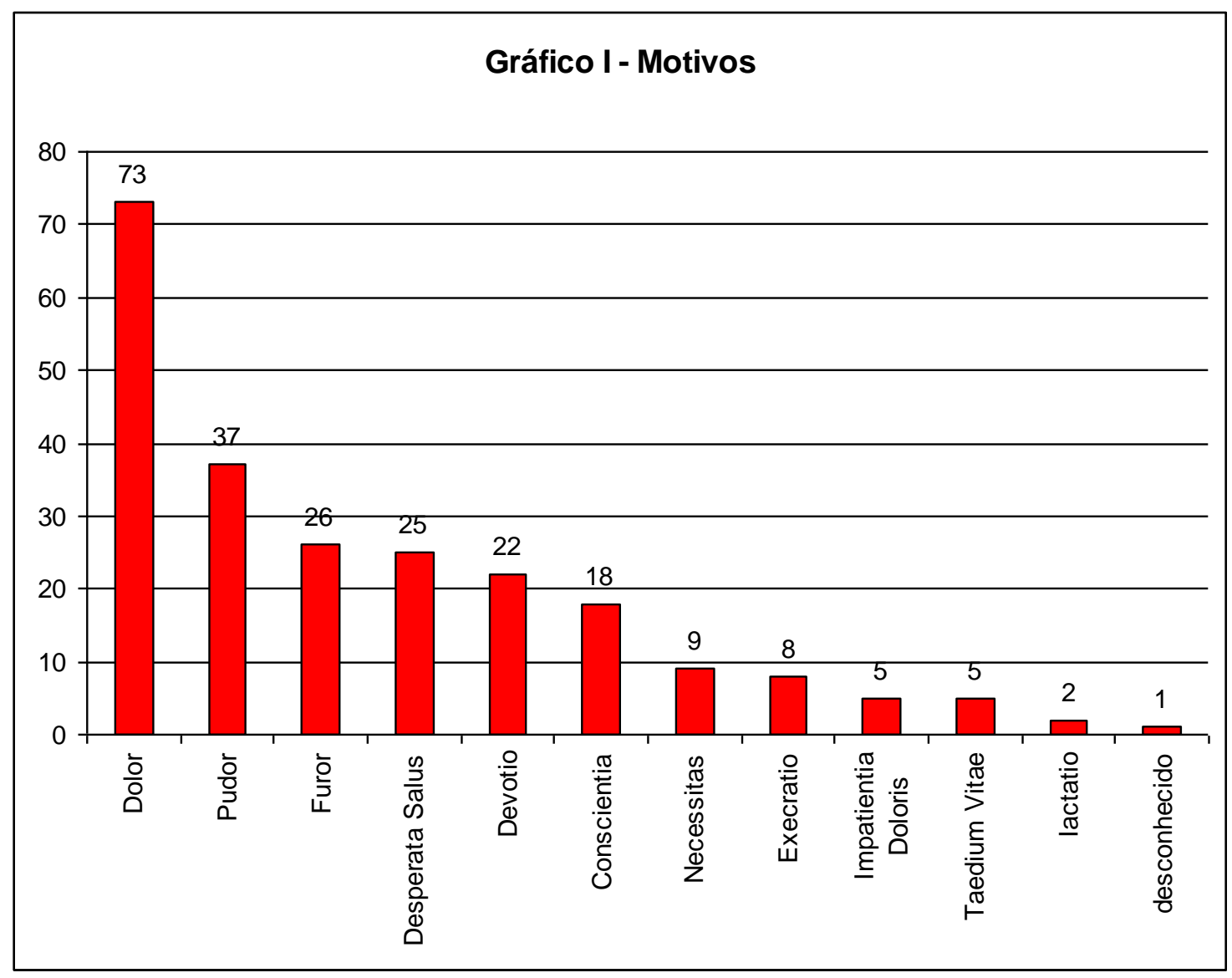



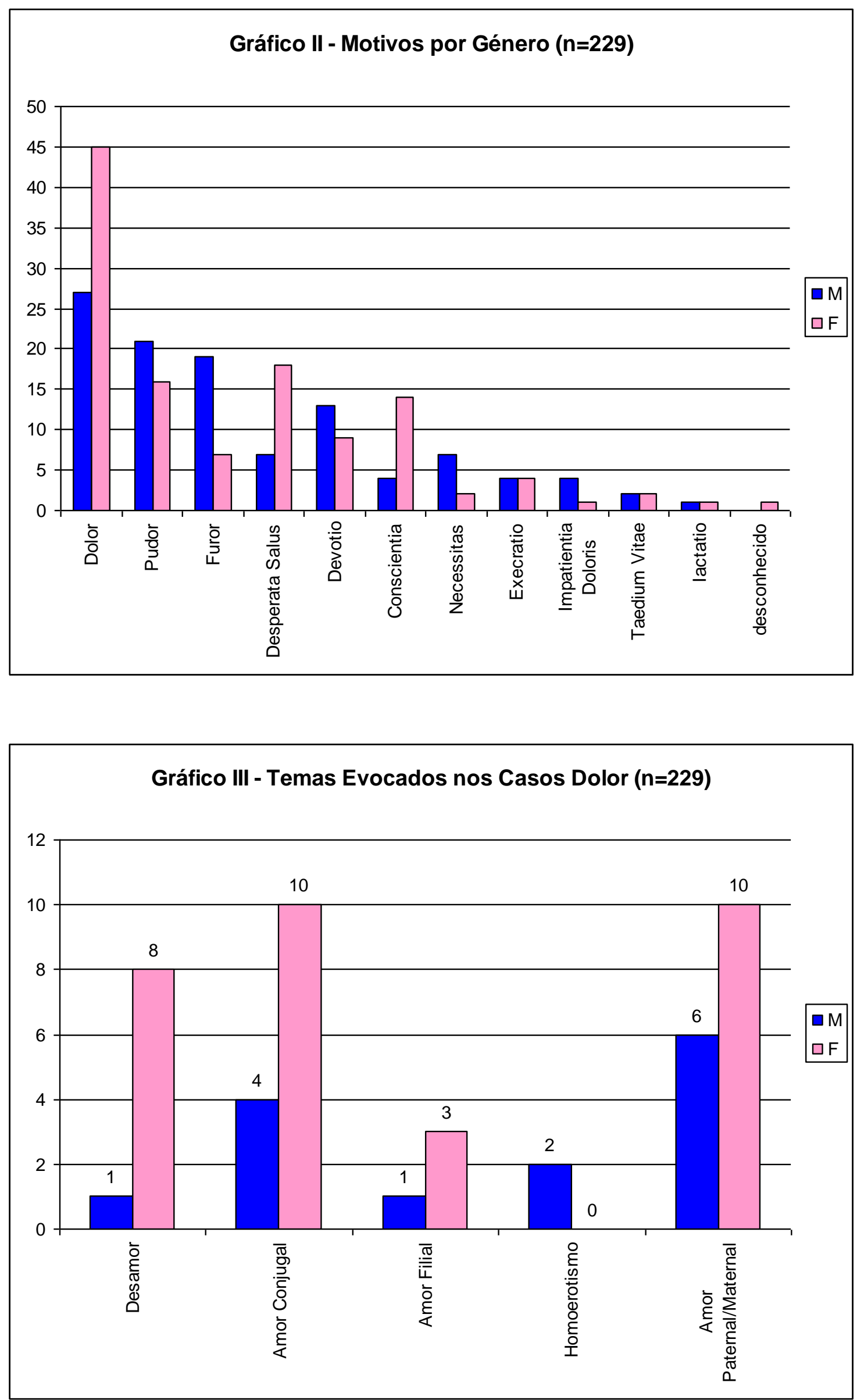

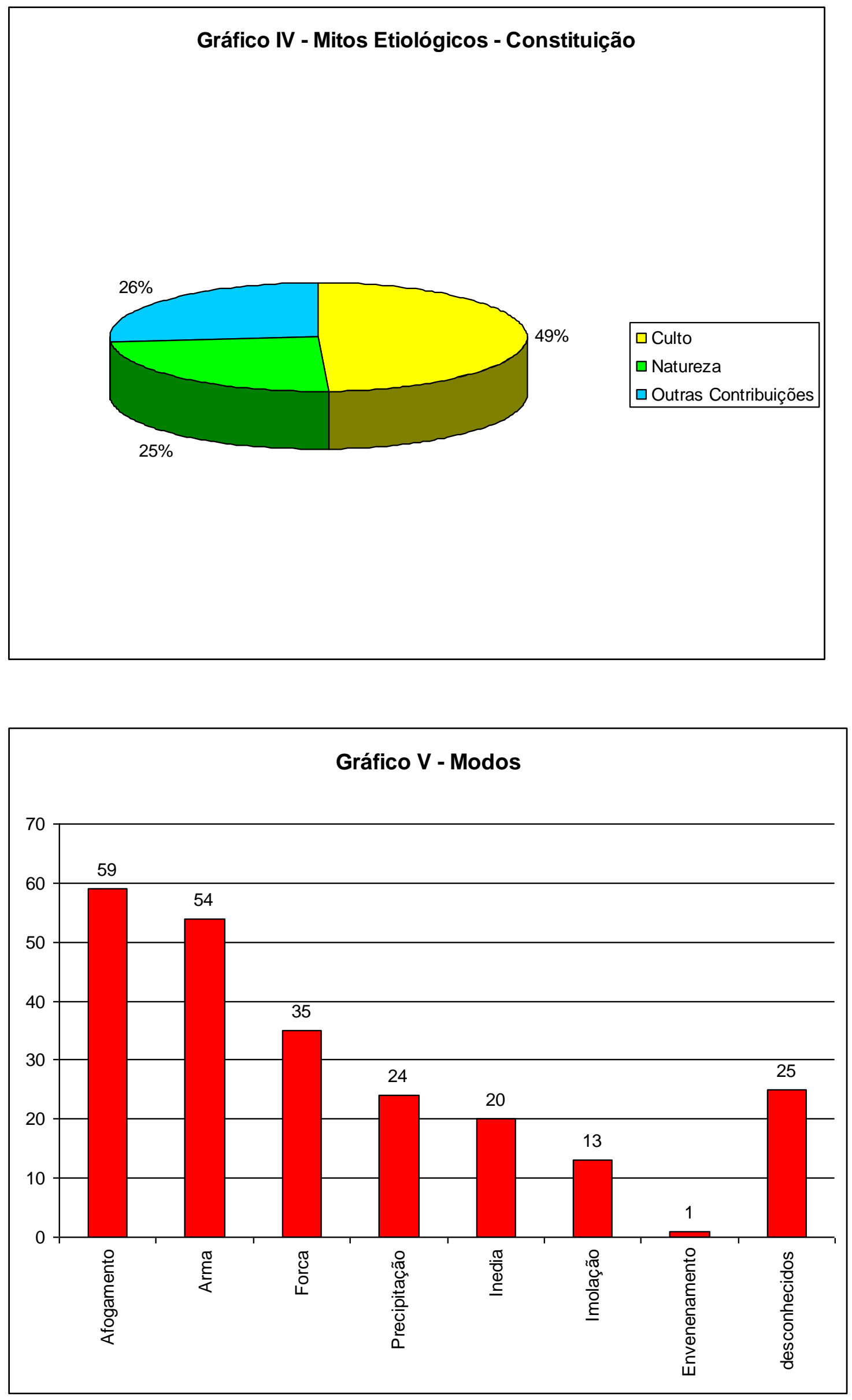

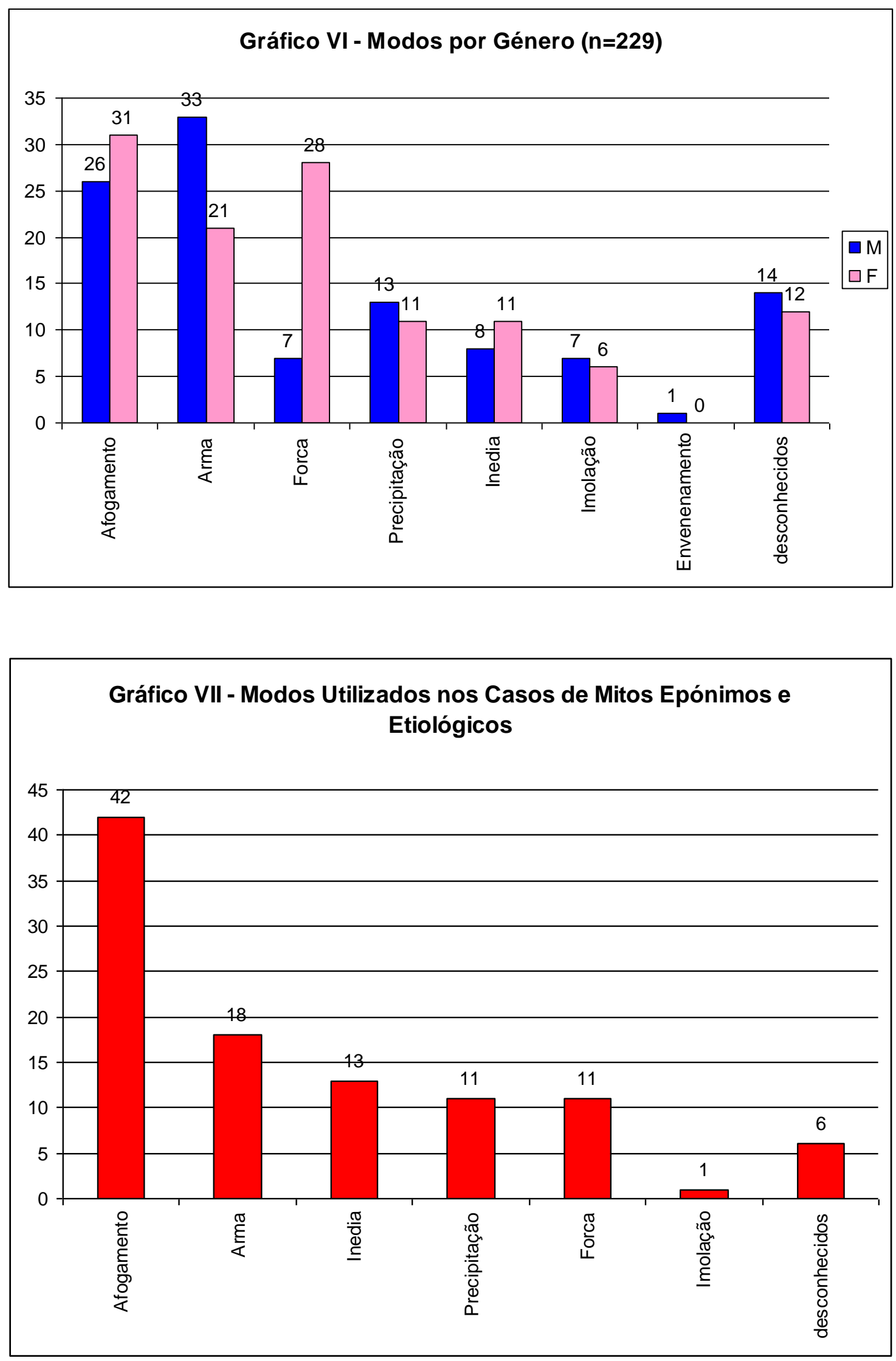


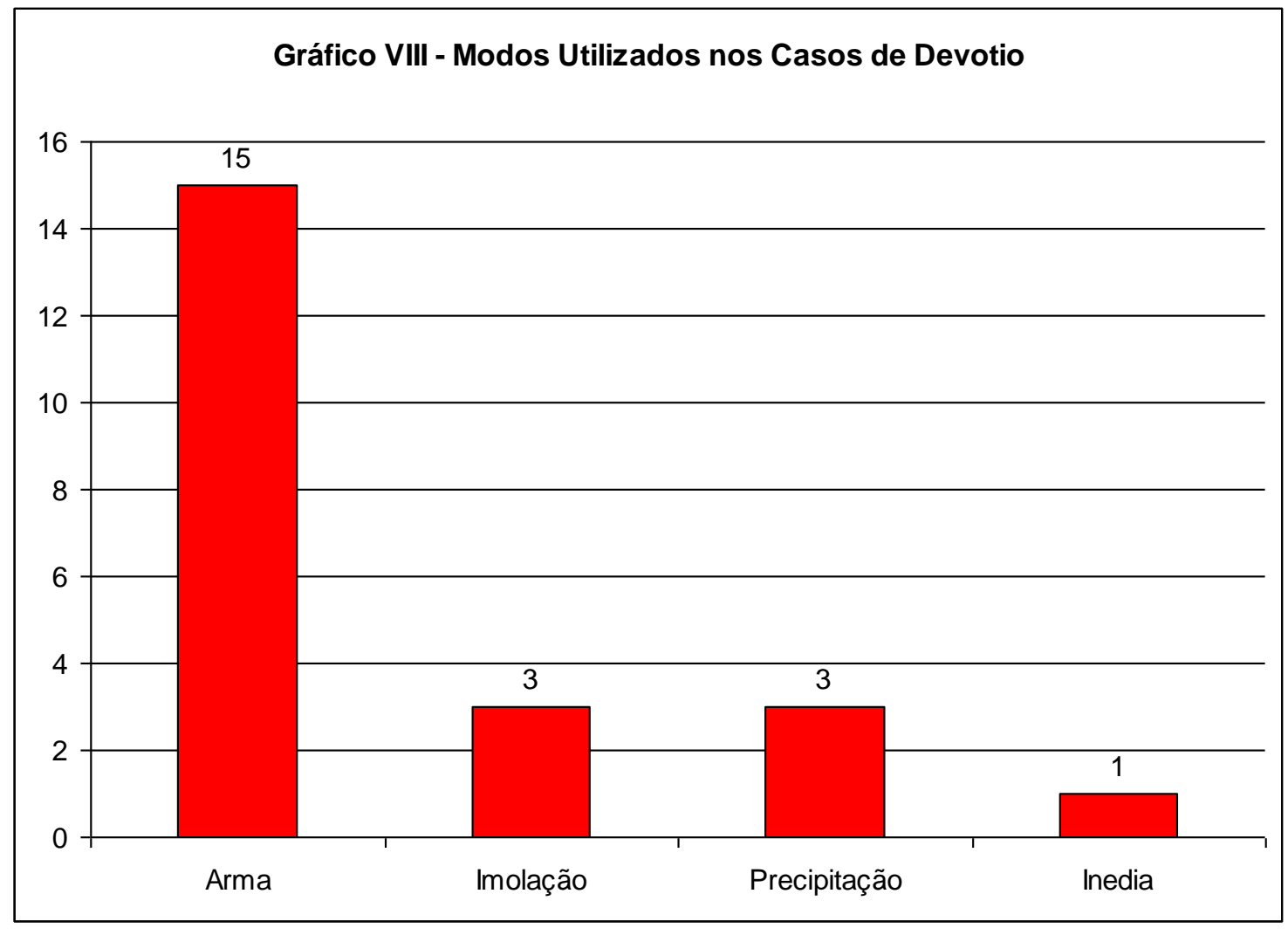




\section{Bibliografia}

W. Burkert (1991), Mito e Mitologia. Lisboa, Edições 70.

Brill's Encyclopaedia of the Ancient World. New Pauly. Antiquity. Eds H. Cancick, H. Schneider; engl. ed.: Ch. F. Salazar, D. E. Orton. Leiden-Boston, 2002-.

M. Citroni, F. E. Consolino, M. Labate, E. Narducci (2006), Literatura de Roma Antiga. Lisboa, Fundação Calouste Gulbenkian.

E. R. Dodds (1988), Os Gregos e o Irracional. Lisboa, Gradiva.

C. Edwards (2007), Death in Ancient Rome. New Haven - London, Yale University Press.

D. Ferreira Leão (2001), Sólon, Ética e Política. Lisboa, Fundação Calouste Gulbenkian.

E. P. Garrison (1991), "Attitudes toward suicide in Ancient Greece", Transactions of American Philological Association 121 1-34.

E. P. Garrison (1995), Groaning Tears: Ethical and Dramatic Aspects in Greek Tragedy. Leiden, E. J. Brill.

F. Rebelo Gonçalves (1966), Vocabulário da Língua Portuguesa. Coimbra, Coimbra Editora.

Y. Grisé (1982), Le Suicide dans la Rome Antique. Paris, Les Belles Lettres.

P. Grimal ( $\left.{ }^{15} 1951\right)$, Dictionnaire de la Mythologie Grecque et Romaine. Paris, Presses Universitaires de France.

P. Grimal ( $\left.{ }^{4} 2004\right)$, Dicionário de Mitologia Grega e Romana. Algés, DIFEL.

P. Grimal (1990) Dictionary of Classical Mythology. London, Penguin Books.

M. Griffin (1986), "Philosophy, Cato and Roman Suicides", Greece \& Rome 33.1 64-77.

T. D. Hill (2004), Ambitiosa Mors: Suicide and Self in Roman Thought and Literature. New York and London, Routledge. 
A. J. L. van Hoof (1990), From Autothanasia to Suicide. Self-Killing in Classical Antiquity. London, Routledge.

J. T. Hooker (1987), "Homeric Society: A Shame-Culture?", Greece \& Rome 34.2 121-125. Lexikon der Alten Welt (1965) Eds. C. Andresen et alii. Zürich - Stuttgart, Artemis Verlag. F. Oliveira, "Suicídio na Roma Antiga", Máthesis 31994 65-93.

The Oxford Classical Dictionary $\left({ }^{3} 2003\right)$. Eds S. Hornblower and A. Spawforth. Oxford, University Press.

Paulys Realencyclopädie der Classischen Altertumswissenschaft (1893-). Neue Bearbeitung, hrsg. G. Wissowa. Stuttgart, Alfred Druckenmüller Verlag.

M. H. Rocha Pereira ( $\left.{ }^{9} 2003\right)$, Estudos de História da Cultura Clássica. Volume I-Cultura Grega. Lisboa, Fundação Calouste Gulbenkian.

M. H. Rocha Pereira ( $\left.{ }^{4} 2009\right)$, Estudos de História da Cultura Clássica. Volume II - Cultura Romana. Lisboa, Fundação Calouste Gulbenkian.

R. W. Sharples (1996), Stoics, Epicureans and Sceptics: An Introduction to Hellenistic Philosophy. New York and London, Routledge.

J. Toner (2009), Popular Culture in Ancient Rome. Cambridge, Polity. 


\begin{tabular}{|c|c|c|c|c|c|c|c|}
\hline PERSONAGEM & GÉNERO & MOTIVO & MODO & TEMA 1 & TEMA 2 & TEMA 3 & LOCAL SUICÍDIO \\
\hline Adrasto 1 & $\mathrm{M}$ & dolor & desconhecido & amor paternal & Sete contra Tebas & Argos & Tebas \\
\hline Adrasto 2 & M & devotio & imolação & Apolo & oráculo & Argos & Tebas \\
\hline Adrasto 3 & $\mathrm{M}$ & dolor & arma & amizade & hospitalidade & engano & Lídia \\
\hline Aglauro & $\mathrm{F}$ & devotio & precipitação & mito etiológico & sexualidade dos deuses & Atena & Atenas \\
\hline Ágrio & $M$ & pudor & desconhecido & Guerra de Tróia & perda de poder político & vingança de família & Etólia \\
\hline Ájax 1 & $\mathrm{M}$ & pudor & arma & Guerra de Tróia & adultério de Helena & prémio de saque (Paládio) & Tróia \\
\hline Ájax 2 & $M$ & furor & arma & Guerra de Tróia & hybris & engano & Tróia \\
\hline Alceste & $\mathrm{F}$ & devotio & arma & amor conjugal & catábase & vingança de Ártemis & Tessália \\
\hline Alcímede & $\mathrm{F}$ & exsecratio & forca & amor conjugal & Argonautas & Iolco & Iolcos \\
\hline Alcínoe 1 & $\mathrm{~F}$ & furor & afogamento & adultério com hóspede & maldição & vingança divina & Mar Mediterrâneo \\
\hline Alcíone 1 & $\mathrm{~F}$ & dolor & afogamento & metamorfose & maldição & engano & Tráquin, praia \\
\hline Alcíone 2 & $\mathrm{~F}$ & dolor & afogamento & metamorfose & mito epónimo (mar) & amor filial & Mar de Alcíone \\
\hline Alciónidas & $\mathrm{F}$ & dolor & afogamento & metamorfose & mito epónimo (mar) & amor filial & Mar de Alcíone \\
\hline Alteia & $\mathrm{F}$ & conscientia & forca & aves de Meleagro & Caçada de Cálidon & destino & Cálidon \\
\hline Altémenes & $M$ & dolor & precipitação & Creta & oráculo & engano & Rodes \\
\hline Amata & $\mathrm{F}$ & conscientia & forca & influência política feminina & príncipe estrangeiro & matriarcado & Lácio \\
\hline Amínias & $\mathrm{M}$ & exsecratio & arma & homo-erotismo & Narciso & desamor & Monte Hélicon \\
\hline Ana & $\mathrm{F}$ & dolor & imolação & príncipe estrangeiro & Eneias & Cartago & Cartago \\
\hline Ancuro & $M$ & devotio & precipitação & oráculo & anel de Polícrates & Ásia & Górdio (capital da Frígia) \\
\hline Anfíon & $M$ & dolor & arma & hybris & amor paternal & progénie & \\
\hline Ânio & $M$ & pudor & afogamento & mito epónimo (hidrónimo) & rapto & Etrúria & Roma \\
\hline Anticleia & $\mathrm{F}$ & dolor & inedia & Guerra de Tróia & catábase & amor maternal & Ítaca \\
\hline Antígona 1 & $\mathrm{~F}$ & necessitas & forca & Édipo & tirania & sepultura & Tebas \\
\hline Antígona 2 & $\mathrm{~F}$ & dolor & forca & desamor & vingança feminina & adultério & Tessália \\
\hline Antíloco & $\mathrm{M}$ & devotio & arma & Guerra de Tróia & manu aliena & provocatio & Tróia \\
\hline Apríate & $\mathrm{F}$ & desperata salus & afogamento & viagens marítimas & desamor & rapto & Lesbos \\
\hline Aquiles & $M$ & necessitas & arma & Guerra de Tróia & manu alinea & amizade & Tróia \\
\hline Aracne & $\mathrm{F}$ & pudor & forca & metamorfose & mito epónimo & hybris & Lídia \\
\hline Ariadne & $\mathrm{F}$ & dolor & forca & desamor & Creta & Teseu & Creta \\
\hline Áspalis & $\mathrm{F}$ & desperata salus & forca & mito etiológico & engano & tirano devasso & Tessália \\
\hline Assáon & $M$ & conscientia & desconhecido & Assíria & caçada & incesto & Assíria \\
\hline Astéria & $\mathrm{F}$ & desperata salus & afogamento & mito epónimo / etiológico & metamorfose & Zeus / Delos & Delos \\
\hline Astíanax & $M$ & necessitas & precipitação & mito epónimo & criança & Guerra de Tróia & Tróia \\
\hline Átis & $M$ & furor & arma & mito etiológico & autocastração & hermafroditismo & Lídia \\
\hline Aura & $\mathrm{F}$ & furor & afogamento & mito etiológico & metamorfose & Dioniso & Frígia \\
\hline Bíblis 1 & $\mathrm{~F}$ & furor & precipitação & metamorfose & mito epónimo & incesto & Ásia \\
\hline Bíblis 2 & $M$ & desperata salus & forca & mito epónimo & incesto & Ásia & Ásia \\
\hline Bolina & $\mathrm{F}$ & desperata salus & afogamento & assédio sexual & Apolo & sexualidade dos deuses & Mar Mediterrâneo \\
\hline Briseu & M & pudor & forca & Guerra de Tróia & Ásia & saque & Tróia \\
\hline Brite & $\mathrm{F}$ & desperata salus & afogamento & mito etiológico & Creta & assédio sexual & Creta \\
\hline Britomártis & $\mathrm{F}$ & desperata salus & afogamento & mito epónimo / etiológico & assédio sexual & suicídio frustrado & Creta \\
\hline Bróteas 1 & $\mathrm{M}$ & furor & imolação & Ártemis & Ásia & caça & Frígia ou Lídia \\
\hline Bróteas 2 & $M$ & taedium vitae & imolação & fealdade masculina & Ásia & vingança de Zeus & \\
\hline Butes & $M$ & furor & afogamento & vingança divina & Dioniso & pirataria & Tessália \\
\hline Cálamo & $M$ & conscientia & inedia & mito epónimo & homo-erotismo & amizade & Frígia \\
\hline Calcas & $\mathrm{M}$ & pudor & inedia & Guerra de Tróia & oráculo & adivinhação & Cólofon \\
\hline Calipso & $\mathrm{F}$ & dolor & desconhecido & Ulisses & desamor & & Ásia \\
\hline Calírroe 1 & $\mathrm{~F}$ & dolor & forca & Guerra de Tróia & desamor & sexualidade feminina & Líbia \\
\hline Calírroe 2 & $\mathrm{~F}$ & conscientia & arma & mito epónimo (hidrónimo) & desamor & Dioniso & Cálidon \\
\hline Cambles & $\mathrm{M}$ & furor & arma & magia & antropofagia & canibalismo & Lídia \\
\hline
\end{tabular}




\begin{tabular}{|c|c|c|c|c|c|c|c|}
\hline PERSONAGEM & GÉNERO & MOTIVO & MODO & TEMA 1 & TEMA 2 & TEMA 3 & LOCAL SUICÍDIO \\
\hline Cânace & $\mathrm{F}$ & necessitas & arma & incesto & exposição de crianças & espada & Tessália \\
\hline Canens & $\mathrm{F}$ & dolor & inedia & mito epónimo (corónimo) & sexualidade feminina & fidelidade masculina & Lácio \\
\hline Cáon & $\mathrm{M}$ & devotio & arma & mito epónimo & Epiro & epidemia & Caónia (Epiro) \\
\hline Cárila & $\mathrm{F}$ & pudor & forca & mito etiológico & folclore & distribuição de trigo & Delfos \\
\hline Castália & $\mathrm{F}$ & desperata salus & afogamento & mito epónimo (hidrónimo) & Apolo & assédio sexual & Delfos \\
\hline Cécrops, filhas de & $\mathrm{F}$ & furor & precipitação & mito etiológico & sexualidade dos deuses & Atena & Atenas \\
\hline Ceneu & $\mathrm{F}$ & desperata salus & desconhecido & metamorfose & hybris & transsexualidade & Tessália \\
\hline Cíane 1 & $\mathrm{~F}$ & pudor & inedia & metamorfose & mito hidrónimo / etiológico & rapto no ritual de casamento & Nápoles \\
\hline Cíane 2 & $\mathrm{~F}$ & devotio & arma & oráculo & anagnórise com anel & incesto & Siracusa \\
\hline Cianipo 1 & M & devotio & arma & oráculo & anagnórise com anel & incesto & Siracusa \\
\hline Cianipo 2 & $\mathrm{M}$ & dolor & imolação & amor conjugal & theriodes bios & Dioniso & Tessália \\
\hline Cicno 1 & $\mathrm{M}$ & pudor & afogamento & metamorfose & castigo da beleza & homo-erotismo & Cálidon (Etólia) \\
\hline Cicno 1, mãe de & $\mathrm{F}$ & dolor & afogamento & amor maternal & suicídio solidário & perda de filho & Etólia \\
\hline Cicno 2 & M & dolor & inedia & metamorfose & homo-erotismo & perda do amado & Ligúria \\
\hline Cidipe & $\mathrm{F}$ & iactatio & desconhecido & mito etiológico & felicidade & filosofia & Argos \\
\hline Cila & $\mathrm{F}$ & desperata salus & afogamento & mito éponimo / etiológico & príncipe estrangeiro & Creta & Mégara \\
\hline Cíniras 1 & $\mathrm{M}$ & pudor & desconhecido & incesto & colonização & Apolo & Chipre \\
\hline Cíniras 2 & $M$ & pudor & desconhecido & Apolo & competição com deus & música & Chipre \\
\hline Cíniras 2, filhas de & $\mathrm{F}$ & dolor & afogamento & Apolo & competição com deus & música & Chipre \\
\hline Cíquiro & $\mathrm{M}$ & dolor & precipitação & mito epónimo / etiológico & engano & caça & Caónia \\
\hline Cleobeia & $\mathrm{F}$ & conscientia & forca & adultério feminino & hospitalidade & dolo feminino & Mileto \\
\hline Cleomedes & $M$ & furor & desconhecido & mito etiológico & metamorfose & jogos Olímpicos & Olímpo \\
\hline Cleópatra & $\mathrm{F}$ & dolor & forca & amor conjugal & perda de marido & intervenção feminina & Cálidon \\
\hline Cleóstrato & $M$ & devotio & precipitacão & mito epónimo & dragão & sacrifício voluntário masculino & Téspias \\
\hline Clície & $\mathrm{F}$ & conscientia & inedia & mito etiológico & metamorfose & Hélio & Pérsia \\
\hline Clímeno & $\mathrm{M}$ & pudor & desconhecido & metamorfose & antropofagia & incesto & Arcádia \\
\hline Clite & $\mathrm{F}$ & dolor & forca & amor conjugal & Argonautas & Ásia & Propôntida (Ásia) \\
\hline Codro & $M$ & devotio & arma & mito etiológico & oráculo & provocatio & Atenas \\
\hline Coresso & $\mathrm{M}$ & devotio & arma & mito epónimo (hidrónimo) & oráculo & desamor & Cálidon \\
\hline Corónides & $\mathrm{F}$ & devotio & arma & mito epónimo & sacrifícios humanos & Hades & Beócia \\
\hline Creúsa 1 & $\mathrm{~F}$ & impatientia doloris & afogamento & Medeia & Jasão & fonte & Corinto \\
\hline Créusa 2 & $\mathrm{~F}$ & pudor & arma & noverca & exposição de crianças & reconhecimento & Delfos \\
\hline Crisipo & $\mathrm{M}$ & pudor & desconhecido & mito etiológico & homo-erotismo & hospitalidade & Peloponeso \\
\hline Dada & $\mathrm{F}$ & pudor & arma & mito epónimo (corónimo) & // com Lucrécia & assédio sexual & Creta \\
\hline Dáfnis & $\mathrm{M}$ & pudor & precipitação & mito etiológico & castigo da beleza & vinho & Sicília \\
\hline Dejanira & $\mathrm{F}$ & conscientia & arma & magia & Héracles & catábase & Tráquin \\
\hline Dicte & $\mathrm{F}$ & desperata salus & afogamento & suicídio frustrado & pesca & assédio sexual & Creta \\
\hline Dido 1 & $\mathrm{~F}$ & devotio & imolação & Cartago & Ásia & África & Cartago \\
\hline \begin{tabular}{|l} 
Dido 2 \\
\end{tabular} & $\mathrm{~F}$ & exsecratio & arma & desamor & // com Héracles sobre a pira & espada do amado & Cartago \\
\hline Dimetes & $M$ & dolor & arma & suicídio sobre túmulo da amada & necrofilia & amor macabro & Trezena \\
\hline Drímaco & $M$ & taedium vitae & arma & mito etiológico & suicídio manu aliena & escravos & Quios \\
\hline Eco & $\mathrm{F}$ & dolor & inedia & mito epónimo & desamor & gruta & Beócia \\
\hline Édipo & $\mathrm{M}$ & pudor & desconhecido & oráculo & incesto & Corinto & Tebas \\
\hline Egéria & $\mathrm{F}$ & dolor & inedia & metamorfose & mito etiológico & amor conjugal & Roma \\
\hline Egeu & $\mathrm{M}$ & dolor & afogamento & mito epónimo & amor paternal & Minotauro & Atenas \\
\hline Eginetas & $M$ & desperata salus & forca & suícidio em massa & vingança divina & peste & Egina \\
\hline Enone & $\mathrm{F}$ & conscientia & forca & guerra de Tróia & medicina feminina & virgindade & Monte Ida (Tróia) \\
\hline Entória, quatro filhos de & $M$ & dolor & forca & mito epónimo / etiológico & // lenda de Erígone & amor filial & Roma \\
\hline Erecteu, filhas de & $\mathrm{F}$ & devotio & arma & mito etiológico & fides & sacrifício feminino & Atenas \\
\hline Erígone 1 & $\mathrm{~F}$ & pudor & forca & Areópago & intervenção feminina & Orestes & Atenas \\
\hline
\end{tabular}




\begin{tabular}{|c|c|c|c|c|c|c|c|}
\hline PERSONAGEM & GÉNERO & MOTIVO & MODO & TEMA 1 & TEMA 2 & TEMA 3 & LOCAL SUICÍDIO \\
\hline Erígone 2 & $\mathrm{~F}$ & dolor & forca & amor filial & Dioniso & // com Antígona & Atenas \\
\hline Erígone 2, companheiras de & $\mathrm{F}$ & furor & forca & mito etiológico & folclore & Dioniso & Atenas \\
\hline Erisícton & $\mathrm{M}$ & furor & inedia & metamorfose & // com Cambles & hybris & Tessália \\
\hline Ésaco & $\mathrm{M}$ & dolor & afogamento & metamorfose & sonho & amor conjugal & Tróia \\
\hline Escédaso & $\mathrm{M}$ & exsecratio & desconhecido & mito etiológico & Esparta & Erínias & Leuctros \\
\hline Escédaso, filhas de & $\mathrm{F}$ & pudor & forca & Esparta & estupro & suicídio colectivo & Leuctros \\
\hline Esfinge & $\mathrm{F}$ & pudor & precipitação & hibridismo & Tebas & perigos das viagens & Tebas \\
\hline Éson & M & necessitas & veneno & Argonautas & ódio fraternal & Jasão & Iolcos \\
\hline Estenebeia & $\mathrm{F}$ & dolor & afogamento & adultério & // com Fedra / Hipólito & desamor & Tirinte \\
\hline Estrímon & M & dolor & afogamento & mito hidrónimo & Guerra de Tróia & amor paternal & Trácia \\
\hline Etra & $\mathrm{F}$ & dolor & desconhecido & amor maternal & Teseu & sexualidade dos deuses & Tessália \\
\hline Eufrates & M & dolor & afogamento & mito epónimo (hidrónimo) & amor paternal & engano & Assíria \\
\hline Euquenor & M & necessitas & arma & Guerra de Tróia & manu aliena & provocatio & Tróia \\
\hline Eurídice & $\mathrm{F}$ & dolor & forca & amor maternal & Antígona & Creonte & Tebas \\
\hline Evadne & $\mathrm{F}$ & dolor & imolação & hybris & amor conjugal & Sete contra Tebas & Tebas \\
\hline Eveno & M & pudor & afogamento & mito hidrónimo & Etólia & Posídon & Etólia \\
\hline Evópis & $\mathrm{F}$ & exsecratio & forca & desamor & incesto & Trezena & Trezena \\
\hline Fásis & M & furor & afogamento & mito epónimo (hidrónimo) & adultério & Erínias & Rio Arcturo \\
\hline Fedra & $\mathrm{F}$ & conscientia & forca & theriodes bios & misoginia & Afrodite & Trezena \\
\hline Fénix & $\mathrm{F}$ & taedium vitae & imolação & // com Hiperbóreos & morte e vida & Egipto & Etiópia \\
\hline Fílis & $\mathrm{F}$ & exsecratio & forca & mito epónimo (corónimo) & Guerra de Tróia & príncipe estrangeiro & Trácia \\
\hline Ganges & $\mathrm{M}$ & pudor & afogamento & mito epónimo (hidrónimo) & incesto & vinho & Índia \\
\hline Glauco & M & iactatio & afogamento & mito etiológico & metamorfose & Creta / Micénios & Antédon \\
\hline Gorge & $\mathrm{F}$ & dolor & afogamento & mito epónimo (hidrónimo) & amor maternal & Corinto & Lago Gorgópis \\
\hline Hália & $\mathrm{F}$ & dolor & afogamento & mito etiológico & incesto & Afrodite & Rodes \\
\hline Haliácmon & $\mathrm{M}$ & furor & afogamento & mito epónimo (hidrónimo) & Tirinte & & Argólida \\
\hline Harpálice 1 & $\mathrm{~F}$ & pudor & desconhecido & metamorfose & incesto & antropofagia & Argos \\
\hline Harpálice 2 & $\mathrm{~F}$ & dolor & desconhecido & mito etiológico & desamor & & \\
\hline Hécuba & $\mathrm{F}$ & pudor & afogamento & metamorfose & mito etiológico & Guerra de Tróia & Mar Mediterrâneo \\
\hline Helena & $\mathrm{F}$ & furor & forca & mito etiológico & Guerra de Tróia & Erínias & Rodes \\
\hline Helíades & $\mathrm{F}$ & dolor & inedia & metamorfose & amor fraternal & // com Cicno & Rodes \\
\hline Hémon & M & dolor & arma & conflito pai / filho & amor e morte & Labdácidas & Tebas \\
\hline Héracles 1 & $\mathrm{M}$ & impatientia doloris & imolação & mito etiológico & manu aliena & magia & Monte Eta \\
\hline Héracles 2 & $\mathrm{M}$ & dolor & imolação & amor conjugal & suicídio frustrado & Héracles & Tessália \\
\hline Hermíone & $\mathrm{F}$ & conscientia & forca & Guerra de Tróia & suicído frustrado & esterilidade feminina & Esparta \\
\hline Hero & $\mathrm{F}$ & dolor & precipitação & amor contrariado & Ásia & Europa & Helesponto \\
\hline Híades & $\mathrm{F}$ & dolor & afogamento & mito etiológico & metamorfose & caça & Nisa \\
\hline Hidaspes & M & pudor & afogamento & mito epónimo (hidrónimo) & incesto & ama & Índia \\
\hline Hilónome & $\mathrm{M}$ & dolor & arma & amor conjugal & Centauros & perda do marido & Tessália \\
\hline Hímero & M & conscientia & afogamento & mito epónimo/hidrónimo & incesto & esturpo & Rio Máraton \\
\hline Hiperbóreos & colectivo & taedium vitae & afogamento & eutanásia & velhice & Apolo & Europa do Norte \\
\hline Hipodamia & $\mathrm{F}$ & conscientia & desconhecido & noverca & Atridas & Pélops & Pisa (Élide) \\
\hline Hipónoo & $\mathrm{M}$ & devotio & imolação & Sete contra Tebas & oráculo & Argos & Tebas \\
\hline Honetes & $\mathrm{M}$ & desperata salus & forca & amor conjugal & exposição de crianças & Afrodite & Babilónia \\
\hline Ídmon & $\mathrm{M}$ & necessitas & desconhecido & adivinhação & Argonautas & destino & Cólquida \\
\hline IIfis & $M$ & exsecratio & forca & mito etiológico & desamor & estatuária & Chipre \\
\hline líone & $\mathrm{F}$ & conscientia & desconhecido & Guerra de Tróia & oráculo & poder feminino & Tróia \\
\hline Ínaco & $\mathrm{M}$ & furor & afogamento & mito epónimo (hidrónimo) & Erínias & rapto & Argólide \\
\hline Indo & $\mathrm{M}$ & necessitas & afogamento & mito epónimo (hidrónimo) & estupro & Índia & Índia \\
\hline Ino 1 & $\mathrm{~F}$ & furor & afogamento & mito etiológico & filicídio & engano & Mégara \\
\hline
\end{tabular}




\begin{tabular}{|c|c|c|c|c|c|c|c|}
\hline PERSONAGEM & GÉNERO & MOTIVO & MODO & TEMA 1 & TEMA 2 & TEMA 3 & LOCAL SUICÍDIO \\
\hline Ino 2 & $\mathrm{~F}$ & dolor & afogamento & mito etiológico & oráculo de Delfos & noverca & Béocia \\
\hline Íole & $\mathrm{F}$ & desperata salus & precipitação & desamor & rapariga como prémio de jogos & Héracles & Ecália \\
\hline Ismeno & $\mathrm{M}$ & impatientia doloris & afogamento & mito epónimo (hidrónimo) & Apolo & Beócia & Beócia \\
\hline Jasão & M & dolor & desconhecido & Argonautas & Cólquida & Tessália & Tessália \\
\hline Jocasta & $\mathrm{F}$ & pudor & forca & incesto & engano & Édipo & Tebas \\
\hline Laodamia & $\mathrm{F}$ & dolor & imolação & amor conjugal & Guerra de Tróia & // com Orfeu e Eurídice & Tessália \\
\hline Leda & $\mathrm{F}$ & pudor & forca & metamorfose & amor maternal & Helena & Esparta \\
\hline Leucatas & M & desperata salus & afogamento & mito epónimo (hidrónimo) & homo-erotismo & Apolo & Lêucade \\
\hline Leucocomante & $\mathrm{M}$ & furor & arma & desamor & homo-erostismo & servitium amoris & Creta \\
\hline Leucótea & $\mathrm{F}$ & dolor & afogamento & mito etiológico & amor maternal & perda de filho & Beócia \\
\hline Licurgo 1 & $\mathrm{M}$ & devotio & inedia & oráculo & Esparta & herói fundador & Delfos \\
\hline Licurgo 2 & M & furor & arma & hybris & Bacantes & Dioniso & Trácia \\
\hline Lucrécia & $\mathrm{F}$ & pudor & arma & poder feminino & estupro & Roma & Roma \\
\hline Macareu & $\mathrm{M}$ & pudor & arma & incesto & exposição de crianças & ama confidente & Lesbos \\
\hline Macária & $\mathrm{F}$ & devotio & arma & mito epónimo & oráculo & sacrificio feminino & Atenas \\
\hline Márato & $\mathrm{M}$ & devotio & arma & mito epónimo (corónimo) & suicídio manu aliena & provocatio & Ática \\
\hline Marpessa & $\mathrm{F}$ & dolor & arma & amor conjugal & // com Enómao e Hipodamia & prémio de jogos & Étolia \\
\hline Medeia & $\mathrm{F}$ & desconhecido & desconhecido & mito epónimo & colonização jónia & Cólquida & Tessália \\
\hline Medo & M & conscientia & afogamento & mito epónimo (hidrónimo) & esturpo & Medo-Persas & Mesopotâmia \\
\hline Meleagro, irmãs de & $\mathrm{F}$ & dolor & inedia & mito epónimo & metamorfose & amor fraternal & Etólia \\
\hline Meles 1 & $\mathrm{M}$ & furor & precipitação & mito etiológico & metecos & servitium amoris & Atenas \\
\hline Meles 2 & $\mathrm{~F}$ & desperata salus & precipitação & homo-erotismo & suicídio duplo & servitium amoris & Atenas \\
\hline Melibeia & $\mathrm{F}$ & desperata salus & precipitação & mito etiológico & navegação & Ártemis & Éfeso \\
\hline Melisso & $\mathrm{M}$ & exsecratio & precipitação & iactatio & homo-erotismo & colonização & Corinto \\
\hline Melo & $\mathrm{M}$ & dolor & forca & mito epónimo / etiológico & amizade & colonização & Chipre \\
\hline Meneceu & M & devotio & arma & Sete contra Tebas & Afrodite & dragão & Tebas \\
\hline Mera & cão & dolor & inedia & mito epónimo / etiológico & sentimentos dos animais & astronomia & Ática \\
\hline Mérops & M & dolor & inedia & metamorfose & mito epónimo & astronomia & Cós \\
\hline Mieno & M & desperata salus & precipitação & mito epónimo (orónimo) & theriodes bios & noverca & Monte Mieno \\
\hline Mirra & $\mathrm{F}$ & taedium vitae & inedia & mito epónimo / etiológico & metamorfose & ama & Ásia \\
\hline Molpadia & $\mathrm{F}$ & desperata salus & afogamento & mito etiológico & Apolo & suicidio frustrado & Quersoneso (Cástabo) \\
\hline Mólpis & M & devotio & arma & mito etiológico & oráculo & Zeus & Élide \\
\hline Narciso 1 & $\mathrm{M}$ & furor & inedia & mito epónimo & theriodes bios & narcisismo & Beócia \\
\hline Narciso 2 & M & furor & arma & mito epónimo & homo-erotismo & exsecratio & Beócia \\
\hline Náuplio & M & dolor & afogamento & mito epónimo & amor paternal & guerra de Tróia & Argos \\
\hline Neera & $\mathrm{F}$ & dolor & desconhecido & amor maternal & Ítaca & perda de filho & Ítaca \\
\hline Nicteu & $\mathrm{M}$ & pudor & desconhecido & Tebas & Zeus & vingança & Sícion \\
\hline Níobe & $\mathrm{F}$ & dolor & precipitação & amor maternal & assédio de pai & perda de filhos & Assíria \\
\hline Nireu & $\mathrm{F}$ & dolor & afogamento & desamor & rede de pesca & Atena & Lêucade \\
\hline Niso 1 & M & pudor & desconhecido & mito etiológico & Mégara & cabelo mágico & Mégara \\
\hline Niso 2 & M & dolor & arma & provocatio & Guerra de Tróia & homo-erotismo & Itália \\
\hline Ocna & $\mathrm{F}$ & conscientia & precipitação & intriga feminina & // com Fedra & misoginia & Beócia \\
\hline Orestes & $\mathrm{M}$ & necessitas & arma & Guerra de Tróia & deus ex machina & matricídio & Argólide \\
\hline Orontes & M & impatientia doloris & afogamento & mito epónimo (hidrónimo) & // com Héracles & Dioniso & Síria \\
\hline Pactolo & M & pudor & afogamento & mito epónimo (hidrónimo) & engano & incesto & Ásia Menor \\
\hline Pangeu & M & pudor & arma & mito epónimo (orónimo) & incesto involuntário & engano & Trácia \\
\hline Párteno & $\mathrm{F}$ & desperata salus & afogamento & mito etiológico & Apolo & suicidio frustrado & Quersoneso (Cástabo) \\
\hline Parténope & $\mathrm{F}$ & pudor & afogamento & mito epónimo / etiológico & hibridismo & Itália & Nápoles \\
\hline Pélia & $\mathrm{F}$ & dolor & forca & amor conjugal & Afrodite & pomba & Chipre \\
\hline Pelopeia & $\mathrm{F}$ & pudor & arma & mito etiológico & Guerra de Tróia & anagnórise & Micenas \\
\hline
\end{tabular}




\begin{tabular}{|c|c|c|c|c|c|c|c|}
\hline PERSONAGEM & GÉNERO & MOTIVO & MODO & TEMA 1 & TEMA 2 & TEMA 3 & LOCAL SUICÍDIO \\
\hline Penélope & $\mathrm{F}$ & dolor & afogamento & Guerra de Tróia & amor conjugal & engano & Ítaca \\
\hline Perdiz & $\mathrm{F}$ & dolor & forca & mito etiológico & amor maternal & Creta & Creta \\
\hline Pílades & $\mathrm{M}$ & dolor & arma & amizade & deus ex machina & suicídio frustrado & Argólide \\
\hline Píramo & M & dolor & arma & mito epónimo (hidro) / etiológico & sexo pré matrimonial & engano & Babilónia (Cilícia) \\
\hline Pireneu & M & furor & precipitação & assédio sexual & tirano abusador & Musas & Fócide \\
\hline Plêiades & $\mathrm{F}$ & desperata salus & afogamento & mito epónimo & assédio sexual & astronomia & Beócia \\
\hline Polidora & $\mathrm{F}$ & dolor & arma & amor conjugal & perda de marido & Etólia & Cálidon \\
\hline Políxena & $\mathrm{F}$ & dolor & arma & Guerra de Tróia & Aquiles & sacrifício feminino & Tróia \\
\hline Praxíteas & $\mathrm{F}$ & devotio & arma & suicídio colectivo & peste & sacrifício feminino & Atenas \\
\hline Quíron & M & impatientia doloris & arma & mito epónimo & renúncia à imortalidade & hibridismo & Tessália \\
\hline Safo & $\mathrm{F}$ & dolor & afogamento & mito etiológico & Lesbos & sacrifícios humanos & Lesbos \\
\hline Ságaris & M & furor & afogamento & mito epónimo (hidrónimo) & vingança divina & Cíbele & Rio Xeróbates \\
\hline Sálmacis & $\mathrm{F}$ & desperata salus & metamorfose & mito epónimo / etiológico & hermafroditismo & ninfas & Cária (Ásia) \\
\hline Selemno & M & dolor & inedia & mito etiológico & desamor & Afrodite & Arcádia \\
\hline Selene & $\mathrm{F}$ & dolor & precipitação & incesto & astronomia & Arcádia & \\
\hline Semíramis & $\mathrm{F}$ & dolor & imolação & metamorfose & bestialismo & oráculo & Assíria \\
\hline Side & $\mathrm{F}$ & desperata salus & arma & mito etiológico & metamorfose & simbologia animal & \\
\hline Sileu, filha de & $\mathrm{F}$ & dolor & inedia & Héracles (trabalho de) & ausência do amado & Tessália & Tessália \\
\hline Sirenes & $\mathrm{F}$ & pudor & afogamento & Guerra de Tróia & hibridismo & Ulisses & Mediterrâneo \\
\hline Solunte & M & dolor & afogamento & mito epónimo (hidrónimo) & Amazonas & Teseu & Bitínia \\
\hline Tánais & M & desperata salus & afogamento & mito epónimo (hidrónimo) & misoginia & incesto & Rio Tánais (actual Rio Don) \\
\hline Teano & $\mathrm{F}$ & conscientia & arma & esterilidade & poder feminino & engano & Icária \\
\hline Temisto & $\mathrm{F}$ & conscientia & desconhecido & infanticídio & engano & noverca & Beócia \\
\hline Téstio & M & dolor & afogamento & mito epónimo (hidrónimo) & incesto & engano & Etólia \\
\hline Testor & $\mathrm{M}$ & desperata salus & arma & suicídio frustrado & novela & disfarce & Cária (Ásia) \\
\hline Teucro & M & dolor & arma & Guerra de Tróia & amor fraternal & navegações & Tróia \\
\hline Timágoras 1 & $\mathrm{M}$ & furor & precipitação & mito etiológico & servitium amoris & meteco & Atenas \\
\hline Timágoras 2 & M & furor & precipitação & servitium amoris & desamor & homo-erotismo & Atenas \\
\hline Tisbe & $\mathrm{F}$ & dolor & arma & mito epónimo (hidro) / etiológico & Ásia & sexo pré matrimonial & Babilónia \\
\hline Valéria & $\mathrm{F}$ & devotio & arma & mito etiológico & sacrifícios humano substituído & Túsculo & Itália \\
\hline Valério & M & pudor & precipitação & incesto involuntário & engano & Túsculo & Itália \\
\hline
\end{tabular}

